INVESTIGATION OF POSSIBLE EFFECTS OF SURFACE COAL MINING

ON HYDROLOGY AND LANDSCAPE STABILITY IN PART OF THE

POWDER RIVER STRUCTURAL BASIN, NORTHEASTERN WYOMING

By Richard M. Bloyd, Pamela B. Daddow, Paul R. Jordan, and Hugh W. Lowham

U.S. GEOLOGICAL SURVEY

Water-Resources Investigations Report 86-4329

Prepared in cooperation with the

WYOMING DEPARTMENT OF ENVIRONMENTAL QUALITY

Cheyenne, Wyoming 
DEPARTMENT OF THE INTERIOR

DONALD PAUL HODEL, Secretary

U.S. GEOLOGICAL SURVEY

Dallas L. Peck, Director

For additional information contact:

District Chief

U.S. Geological Survey

2120 Capitol Avenue

P.0. Box 1125

Cheyenne, Wyoming 82003

Telephone: (307) 772-2153
Copies of this report can be purchased from:

$-$

U.S. Geological Survey Books and Open-File Reports Federal Center, Building 41 Box 25425 Denver, Colorado 80225 Telephone: (303) 236-7476 
Abstract-10

Introduction-... 2

Purpose and scope-1.

Study area-.-.--

Potential hydrologic effects of coal mining-

Geologic setting-_... 9

Previous studies-.....

Acknowledgments-

Description of the Belle Fourche River basin- 12

Climate-...... 12

Geology--..- 12

Soil characteristics and vegetation- 15

Streamflow-_...

Average annual discharge-16

Flow duration- 16

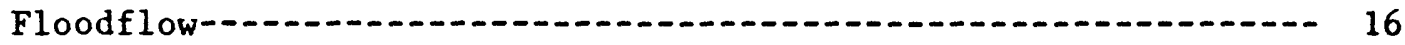

Computer model of the surface-water hydrology of the Belle Fourche River basin-....... 21

Data preparation-1. 22

Calibration-. 24

Verification-1. 31

Sensitivity analysis-a. 31

Effects of mining

Transferability to Little Powder River basin-_. 40

Landscape stability-... 42

Description of drainage networks- 42

Study sample-..... 44

Use of data-........ 44

Illustrative example-1. 63

Evaluation of basin stability- 64

Application of geomorphic relations- 64

Effects of mining on landscape stability- 68

Ground-water system- 70

Conceptual model

Ground-water flow-_. 72

Recharge and discharge- 77

Uncalibrated computer model- 77

As sumptions - 78

Boundaries and variable grid-_a 78

Hydrologic data-_at 79

Documentation of calibration problems- 83

Discussion of unsuccessful model-_. 85

Premining and postmining ground-water quality-... 86

Summary and conclusions-

References-_. 


\section{FIGURES}

Figures 1-4. Maps showing:

Page

1. Location of study area and Powder River structural basin in Wyoming-..

2. Location of Belle Fourche River basin, coal mines, and area of ground-water-flow model---

3. Surficial geology-

4. Average annual precipitation and location of climatological and streamflow stations--..- 13

5-6. Graphs showing:

5: Flow-duration curves of unit discharge for drainage areas smaller than 500 square miles--..-

6. Flow-duration curves of unit discharge for drainage areas larger than 500 square miles-..-

7. Peak discharge as a function of drainage area in the Belle Fourche and Little Powder River basins.....-

8. Map showing data sites and subdivisions used for the surface-water model of the Belle Fourche River basin----

9-11. Graphs showing measured and simulated streamflow at:

9. Station 06425780 Belle Fourche River above Dry Creek, near Piney, Wyo., May-June 1978-

10. Station 06426500 Belle Fourche River below Moorcroft, Wyo., May-June 1978-

11. Station 06426500 Belle Fourche River below Moorcroft, Wyo., during verification period, May-June 1982----

12. Graph showing simulated streamflow of Belle Fourche River at inlet of Keyhole Reservoir using rainfall B for premining, during-mining, and postmining conditions-----

13. Sketch of third-order basin showing first-, second-, and third-order streams-- 43

14. Map showing location of basins used to determine physical characteristics-- 45

15-21. Graphs showing relation of:

15. Basin order to drainage area- 56

16. Number of streams to basin order- 57

17. Basin relief to basin order- 58

18. Basin length to basin order. 59

19. Channel slope to basin order- 60

20. Stream length to basin order- 61

21. Stream length of the segments of a given order to stream order- 62

22-24. Graphs showing average hypsometric curve for:

22. Second-order basins-- 65

23. Third-order basins-- 66

24. Fourth-order basins-- 67

25. Graph showing comparison of channel slopes for natural and postmining basins-- 69

26. Diagrammatic section showing the three geohydrologic units of the shallow aquifer system- 71 
Figures 27-31. Maps showing:

Page

27. Approximate water-level contours for the Wasatchupper Tongue River aquifer-a 73

28. Approximate potentiometric surface of the WyodakAnderson aquifer-15

29. Approximate potentiometric surface of the lower Tongue River-Lebo aquifer-- 76

30. Variable grid and boundaries for computer model of flow in the shallow aquifer system-80

31. Altitude and configuration of the top of the WyodakAnderson coal bed-... 82

32-37. Maps showing premining and postmining concentrations in ground water of:

32. Dissolved solids-_. 88

33. $\mathrm{pH}$ (laboratory values)

34. Sulfate-1 90

35. Manganese--aro 91

36. Boron-1. 92

37. Nitrate plus nitrite (as nitrogen) 93

\section{TABLES}

Table 1. Coal mines in the study area- 7

2. Monthly distribution of precipitation at selected climatological stations- 14

3. Monthly distribution of temperature at selected climatological stations- 14

4. Natural vegetation in study area- 15

5. Streamflow data for continuous-record stations in the Belle Fourche and Little Powder River basins-- 17

6. Selected values of precipitation and streamflow for time periods used in the surface-water model-ar 25

7. Values for hydrologic characteristics used in surfacewater-model calibration-- 27

8. Simulated and measured streamflow volumes and dissolved-solids and sulfate concentrations during calibration period--.---

9. Effects of changes in values for hydrologic characteristics on minimum, mean, and maximum streamflow and dissolved-solids concentrations during a 2-month simulation period on a hypothetical land segment and stream reach-a. 33

10. Changes in simulated streamflow from premining to duringmining and postmining conditions using rainfall $\overline{\mathrm{B}}-\ldots$

11. Changes in simulated dissolved-solids concentrations from premining to during-mining and postmining conditions using worst-case conditions with rainfall A-co

12. Changes in simulated dissolved-solids concentrations from premining to during-mining and postmining conditions using worst-case conditions with rainfall B-C 
Table 13. Sensitivity of predicted changes in streamflow and dissolved solids to bias in INFILT or UZSN for postmining conditions and rainfall B-... 39

14. Characteristics measured in landscape-stability analysis-...- 46

15. Summary of physical characteristics for second-, third-, and fourth-order basins-... 48

16. Summary of physical characteristics for first-order basins---- 50

17-20. Statistical properties for:

17. First-order basins-

18. Second-order basins-_. 52

19. Third-order basins- 53

20. Fourth-order basins-_. 54

21. Summary of correlation analysis of physical characteristics--- 55

22. Summary of regression analysis

\section{CONVERSION FACTORS AND VERTICAL DATUM}

For those readers who may prefer to use metric units, the conversion factors for inch-pound units used in this report are listed below:

Multiply inch-pound unit

acre

acre-foot

cubic foot per second $\left(\mathrm{ft}^{3} / \mathrm{s}\right)$

foot ( $f t$ )

foot per foot

foot per day ( $f t / d$ )

foot squared per day $\left(\mathrm{ft}^{2} / \mathrm{d}\right)$

inch (in.)

inch per hour

inch per year (in/yr)

mile ( $\mathrm{mi}$ )

mile per hour $(\mathrm{mi} / \mathrm{h})$

mile per square mile

square mile $\left(\mathrm{mi}^{2}\right)$
By

$$
\begin{gathered}
0.4047 \\
1,233 \\
0.02832 \\
0.3048 \\
0.3048 \\
0.3048 \\
0.9290
\end{gathered}
$$

25.40

25.40

25.40

1.609

1.609

0.622

2.590
To obtain metric unit

hectare

cubic meter

cubic meter per second

meter

meter per meter

meter per day

meter squared per day

millimeter

millimeter per hour

millimeter per year

kilometer

kilometer per hour

kilometer per square

kilometer

square kilometer

Temperatures in degrees Fahrenheit $\left({ }^{\circ} \mathrm{F}\right)$ can be converted to degrees Celsius $\left({ }^{\circ} \mathrm{C}\right)$ as follows:

$$
{ }^{\circ} \mathrm{C}=5 / 9\left({ }^{\circ} \mathrm{F}-32\right)
$$

National Geodetic Vertical Datum of 1929 (NGVD of 1929): A geodetic datum derived from a general adjustment of the first-order level nets of both the United States and Canada, formerly called "mean sea level." 


\title{
INVESTIGATION OF POSSIBLE EFFECTS OF SURFACE COAL MINING ON HYDROLOGY AND LANDSCAPE STABILITY IN PART OF THE POWDER RIVER STRUCTURAL BASIN, NORTHEASTERN WYOMING
}

By Richard M. Bloyd, Pamela B. Daddow, Paul R. Jordan, and Hugh W. Lowham

\begin{abstract}
The Powder River structural basin in northeastern Wyoming is an area where the Wyoming Department of Environmental Quality is required to assess cumulative effects of mining because of existing and pending applications for surface-coal-mining operations. This investigation was conducted to determine the effects of surface-coal mining on the surface- and ground-water systems in a 5,400-square-mile area that includes 20 major coal mines. Three approaches were used in the investigation: A surface-water model, a landscape-stability analysis, and a ground-water-flow model.
\end{abstract}

A surface-water model was developed for the Belle Fourche River basin. The Hydrological Simulation Program-Fortran model was used to simulate changes in streamflow and changes in dissolved-solids and sulfate concentrations. For the calibration period, May and June 1978, simulated streamflow volume at the downstream station, Belle Fourche River below Moorcraft, was about 6 percent less than measured streamflow volume. During verification, simulated peak flows approximated the measured peak flows, but the simulated volume was much larger than the measured volume. Simulated and measured concentrations of dissolved solids differed by 18 percent and of sulfate by 35 percent during calibration and verification.

The effects of mining on streamflow and dissolved-solids and sulfate concentrations were simulated by the model, using less than and greater than average rainfall for premining, during-mining, and postmining conditions. Values of hydrologic characteristics resulting from adjustment during calibration were used in the simulation of the premining condition. The following values of hydrologic characteristics were changed to represent the disturbed and reclaimed areas: Average length and slope of overland-flow path, infiltration capacity, and dissolved-solids concentration in interflow and in groundwater contribution. The during-mining condition assumed the maximum disturbed area for all mines at the same time. The postmining condition assumed the combined permit areas were reclaimed, and the sediment and flood-storage ponds remained in place for 10 years after completion of reclamation. Simulated streamflows resulting from less than average rainfall were small, changes in flow from premining to during-mining and postmining conditions were less than 2.5 percent, and changes in mean dissolved-solids and sulfate concentrations ranged from 1 to 7 percent. Between premining and postmining conditions, changes in median streamflows simulated using greater than average rainfall ranged from 4 to 22 percent at four sites downstream from mining, and simulated dissolved-solids and sulfate concentrations for streamflows exceeding 1.0 cubic foot per second were decreased by as much as 49 percent. 
Physical characteristics were measured for 102 drainage basins, and regression relations were developed for characteristics important to landscape stability to aid in designing the reconstruction of drainage networks. The results of hypsometric analyses for evaluating the stability of natural basins indicate the larger unmined basins are relatively stable, and statistical data from these basins. may be used to design the placement of material within a mined basin to approximate natural, stable landscapes in the area.

The attempt to define and simulate the ground-water system in the area using a ground-water-flow model was unsuccessful; the steady-state groundwater-flow model could not be calibrated. The modeling effort failed principally because of insufficient quantity and quality of data to define the spatial distribution of aquifer properties; the hydraulic-head distribution within and between aquifers; and the rates of ground-water recharge and discharge, especially for steady-state conditions.

\section{INTRODUCT ION}

The Wyoming Department of Environmental Quality, Land Quality Division, in cooperation with the Office of Surface Mining, Department of the Interior, assesses the probable cumulative effects of mining and anticipated mining on the surface- and ground-water systems each time a coal-mining permit application is made. The assessment is required by the Surface Mining Control and Reclamation Act of 1977 and the rules and regulations of the Wyoming Department of Environmental Quality.

The Powder River structural basin in northeastern Wyoming is an area where the Wyoming Department of Environmental Quality is required to assess cumulative effects of mining because of existing and pending applications for surface coal-mining operations. In order to provide information needed to assess the effects of coal mining, the U.S. Geological Survey, in cooperation with the Wyoming Department of Environmental Quality, conducted a study of the hydrology of part of the Powder River structural basin (fig. 1).

\section{Purpose and Scope}

The purpose of the study, which was conducted during 1983-84, was to: (1) Define the hydrologic system in the area; (2) determine the effects of surface coal mining on streamflow, surface-water quality, ground-water systems, and ground-water quality; and (3) determine geomorphic relations for use in the design of stable drainage networks and landscapes for reconstructed drainage basins. In order to determine the effects of coal mining, a surfacewater model and a ground-water-flow model were developed.

The effects of mining on the ground-water system were to be predicted by simulation of the conceptual flow system using a ground-water-flow model. The aquifer system in the study area is too complex to be modeled accurately. Therefore, a conceptual model was developed that simplified the system and made it manageable for digital-computer simulation. However, the conceptual model did not accurately represent the actual aquifer system because of the size of the modeled area and understanding of the complexity of that aquifer system. Some of the necessary simplifying assumptions were incorrect, and existing data used in the model to describe the conceptual flow systems were inadequate. The computer model was not successfully calibrated, and therefore, the effects of mining on the ground-water-flow system were not calculated. 


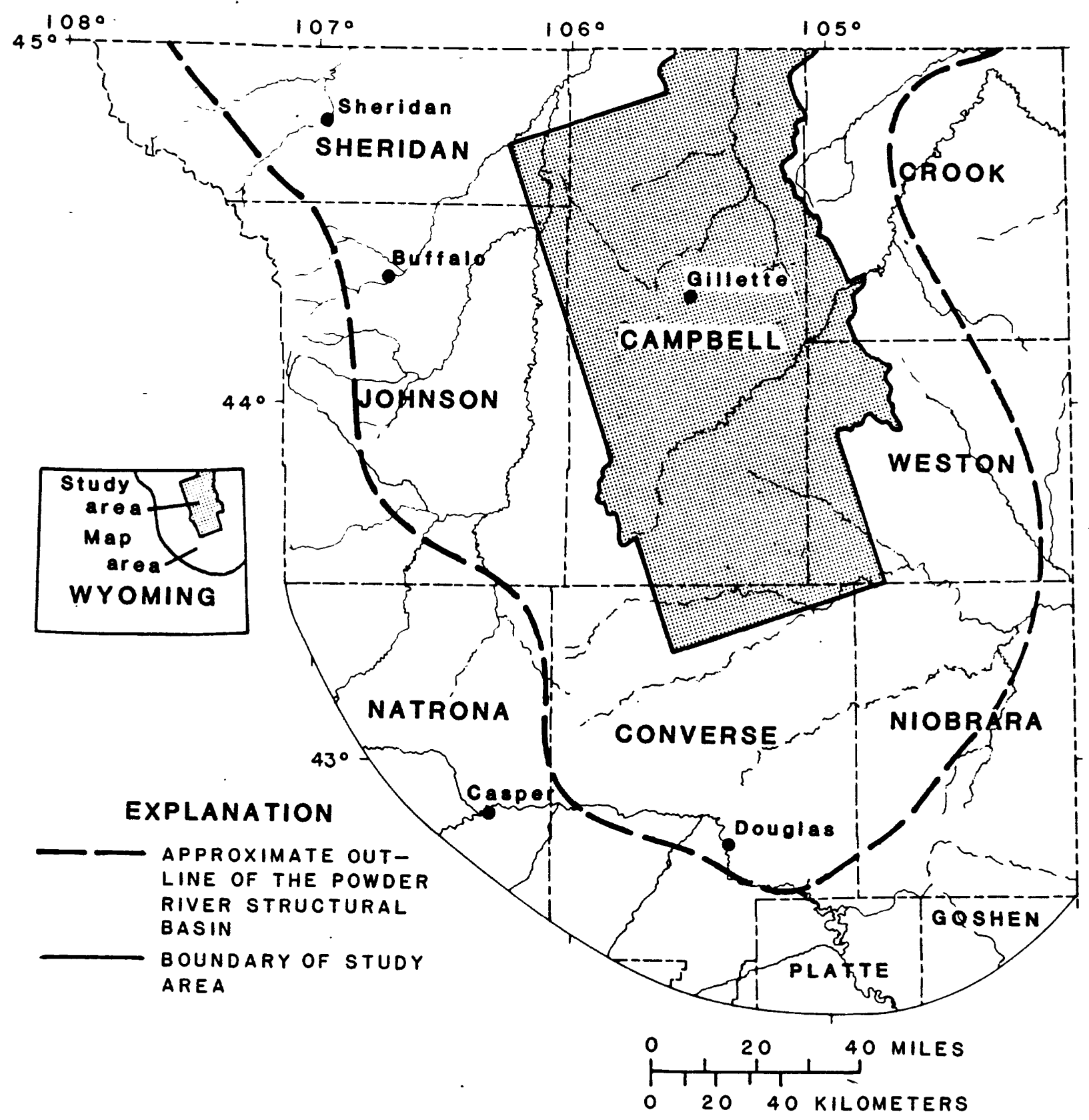

Figure 1.--Location of study area and Powder River structural basin in Wyoming. 
Without a calibrated ground-water-flow model, concepts of the hydrologic system could not be tested and better defined, and the effects of coal mining on ground-water systems could not be determined. Because of the unsuccessful model, the purpose and emphasis of the report are different than those of the study.

The purposes of the report are: (1) Describe the surface-water model and the calculated effects of mining on streamflow and surface-water quality in the Belle Fourche River basin and evaluate the transfer value of the model results to the Little Powder River basin; (2) describe the geomorphic relations usable for the design of stable drainage networks and landscapes for reconstructed drainage basins; (3) describe the shallow aquifer system and the differences between premining and postmining ground-water quality; and

(4) describe the ground-water-flow model and the problems encountered during unsuccessful attempts to simulate the shallow aquifer system.

Principal sources for the large quantities of hydrologic data were the files of the Wyoming Department of Environmental Quality, the Wyoming State Engineer, and the U.S. Geological Survey. Special emphasis was placed on using data from the mine-permit applications on file with the Wyoming Department of Environmental Quality. Most of the Wyoming Department of Environmental Quality data resulted from State requirements imposed on mining companies to collect adequate site-specific baseline data to complement the operator's mine and reclamation plans.

The two major basins affected by coal mining in the eastern part of the Powder River structural basin are the Belle Fourche River and Little Powder River basins. Time constraints allowed surface-water modeling of only the Belle Fourche River basin. Initially, the use of the surface-water model of the Belle Fourche River basin was considered for the Little Powder River basin in order to estimate the effects of coal mining on the surface-water hydrology. However, the comparison between the two basins indicated differences that may preclude transferability of model results from the Belle Fourche River basin for accurate prediction in the Little Powder River basin. The comparison is presented in a section on transferability in order to more completely describe the surface-water hydrology of the study area.

Early in the study, a surface-water model of the Caballo Creek drainage, a part of the Belle Fourche River basin, was developed (Jordan, Bloyd, and Daddow, 1984). The purpose of the model was to estimate the effects of mining on the surface-water hydrology and to examine the uses and limitations of the model. Two periods, April 15 to May 31, 1978, and May 1 to May 31, 1982, were modeled in the early effort. Water quality was not considered; only streamflow was modeled.

The results of the Caballo Creek model indicate little, if any, streamflow change between premining, during-mining, and postmining conditions. The principal reason for the absence of change was the rapid infiltration rate used in the model, which nearly precluded the calculation of surface runoff (Jordan, Bloyd, and Daddow, 1984). However, further study indicates more surface runoff and less ground-water contribution to streamflow occurs, along with more spatial variation in ground-water contributions. Because the focus 
in this report is on the effects of several mines on the hydrology in a large basin, the earlier Caballo Creek model described by Jordan, Bloyd, and Daddow (1984) is superceded by the inclusion of the Caballo Creek drainage within a model of the entire Belle Fourche drainage.

Data used in developing the geomorphic relations for defining landscape stability were obtained from a large sample of drainage basins which are all located within $15 \mathrm{mi}$ of a permit area. Physical characteristics are related to first-, second-, and third-order streams. The use of the relations and graphs generated from the data is reinforced with an illustrative example. The effects of mining on landscape stability is determined for a sample of 12 small basins. in the study area.

The unsuccessful ground-water modeling effort is documented in order to provide future investigators an insight to problems of modeling the complex aquifers in the Powder River structural basin, particularly on a large scale. The documentation includes the description of the shallow aquifer system modeled, simplifying assumptions, boundary conditions, the variable grid, and initial hydrologic data required for calibration.

\section{Study Area}

The study area consists of about $5,400 \mathrm{mi}^{2}$ in northeastern Wyoming, mostly in Campbell County (fig. 1). The parts of the area that were studied with emphasis on surface-water hydrology (Belle Fourche River basin) and on ground-water hydrology (ground-water-flow model) are delineated in figure 2. The boundaries of the study area include all of the major coal mines (see fig. 2) in the eastern part of the Powder River structural basin.

Most of the study area is drajned by the Belle Fourche and Little Powder River and their tributaries. The area of the Belle Fourche River basin is about 1,720 $\mathrm{mi}$; the area of the Little Powder River basin is about 1,380 mi. The remainder of the area is drained by tributaries of the Powder and Cheyenne Rivers.

The topographic features of the area include dissected uplands in the western part, rolling divides in the central part, a clinker-capped escarpment along the eastern side of the rolling divides, and a gently rolling plain in the eastern part. Land-surface altitudes range from $3,400 \mathrm{ft}$ in the northern part to $6,000 \mathrm{ft}$ at Pumpkin Butte in the southwestern part (Breckenridge and others, 1974).

\section{Potential Hydrologic Effects of Coal Mining}

In order to assess potential hydrologic effects of mining, activities of 20 mines (figs. 2 and 30 , and table 1 ) were considered in this study. All but one of the mines considered are in Campbell County. The earliest coal production in the area, from the Wyodak Mine, began in 1922. In the $1960^{\circ} \mathrm{s}$, many surface coal mines were proposed for the area. Start-up dates for mines are projected through 1985 (table 1). In terms of surface area to be disturbed, the Caballo Mine will be the largest mine in the area. 


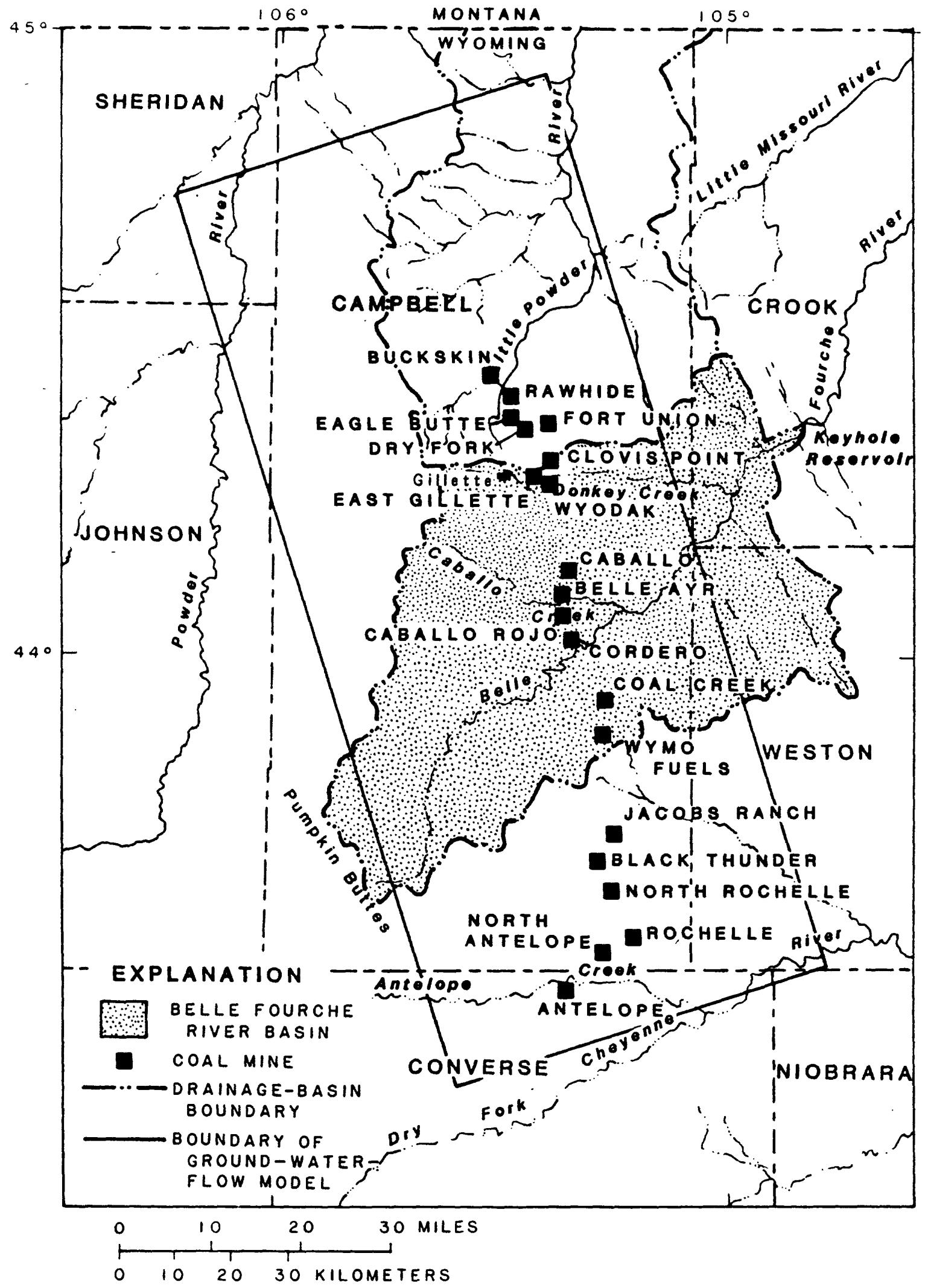

Figure 2.--Location of Belle Fourche River basin, coal mines, and area of ground-water-flow model. 
Table 1.--Coal mines in the study area

[From mine permits on file with Wyoming Department of Environmental Quality]

\begin{tabular}{|c|c|c|c|c|}
\hline \multirow[b]{2}{*}{ Mine } & \multicolumn{2}{|c|}{ Production } & \multirow{2}{*}{$\begin{array}{c}\text { Surface area dis- } \\
\text { turbed through } 1982 \\
\text { (acres) }\end{array}$} & \multirow{2}{*}{$\begin{array}{c}\text { Total surface area } \\
\text { to be disturbed } \\
\text { (acres) }\end{array}$} \\
\hline & $\begin{array}{l}\text { Start-up } \\
\text { date }\end{array}$ & $\begin{array}{c}\text { Projected } \\
\text { date }\end{array}$ & & \\
\hline $\begin{array}{l}\text { Antelope } \\
\text { Belle Ayr } \\
\text { Black Thunder } \\
\text { Buckskin } \\
\text { Caballo }\end{array}$ & $\begin{array}{l}1982 \\
1972 \\
1977 \\
1981 \\
1979\end{array}$ & $\begin{array}{l}2011 \\
2001 \\
2014 \\
1996 \\
2021\end{array}$ & $\begin{array}{r}219 \\
1,844 \\
1,488 \\
631 \\
855\end{array}$ & $\begin{array}{l}5,900 \\
4,334 \\
8,170 \\
1,315 \\
9,104\end{array}$ \\
\hline $\begin{array}{l}\text { Caballo Rojo } \\
\text { Clovis Point } \\
\text { Coal Creek } \\
\text { Cordero } \\
\text { Dry Fork }\end{array}$ & $\begin{array}{l}1983 \\
1979 \\
1982 \\
1976 \\
1984\end{array}$ & $\begin{array}{l}2007 \\
1998 \\
2012 \\
2006 \\
2005\end{array}$ & $\begin{array}{r}0 \\
646 \\
765 \\
1,417 \\
0\end{array}$ & $\begin{array}{l}4,818 \\
1,047 \\
8,310 \\
8,232 \\
2,905\end{array}$ \\
\hline $\begin{array}{l}\text { Eagle Butte- } \\
\text { East Gillette } \\
\text { Fort Union } \\
\text { Jacobs Ranch } \\
\text { North Antelope }\end{array}$ & $\begin{array}{l}1976 \\
1983 \\
1979 \\
1975 \\
1982\end{array}$ & $\begin{array}{l}2009 \\
2012 \\
1992 \\
2006 \\
2026\end{array}$ & $\begin{array}{r}805 \\
0 \\
155 \\
1,547 \\
443\end{array}$ & $\begin{array}{r}3,470 \\
2,702 \\
419 \\
4,691 \\
2,709\end{array}$ \\
\hline $\begin{array}{l}\text { Rawhide } \\
\text { North Rochelle } \\
\text { Rochelle } \\
\text { Wymo Fuels } \\
\text { Wyodak }\end{array}$ & $\begin{array}{l}1976 \\
1983 \\
1985 \\
1983 \\
1922\end{array}$ & $\begin{array}{l}2004 \\
2012 \\
2027 \\
1995 \\
2016\end{array}$ & $\begin{array}{r}1,003 \\
0 \\
0 \\
0 \\
463\end{array}$ & $\begin{array}{r}4,735 \\
3,271 \\
5,312 \\
750 \\
1,720\end{array}$ \\
\hline
\end{tabular}

The potential for adverse effects on the hydrology of the mining area exists because of changes in physical conditions. Surface mining of coal disrupts watersheds and stream equilibrium and may change the quantity and quality of surface-water runoff from a mined area. Ground-water flow and quality also can be altered. A general discussion of effects on the land surface and hydrology follows.

Coal removal results in a change in topography. In the study area, the removal of coal beds typically results in the lowering and flattening of the land surface after mining and reclamation are completed. The overburden ranges in thickness from 0 to $200 \mathrm{ft}$ where mining currently (1985) occurs in the Powder River structural basin. The Wyodak coal bed, which is the coal bed mined in the area, ranges in thickness from 5 to $190 \mathrm{ft}$. Even though the overburden volume is increased during mining as it is broken and disturbed, the increase in volume of the replaced overburden material usually is not sufficient to compensate for the removal of the thick coal beds.

Besides a lowering of the land surface, the appearance of the mined area may be changed. This is especially so in areas with abrupt changes in the natural landscape. Abrupt changes in a landscape probably cannot be recreated during reclamation. The typical reclaimed land surface remains rolling but generally is much subdued. 
A more in-depth discussion of potential effects of coal mining on the land surface is presented by Hadley and Keefer (1975). They specifically discuss the Gillette, Wyoming, area.

Alterations of the land-surface topography can cause substantial changes in the hydraulics of stream systems and in drainage patterns. For example, after land is disturbed and before vegetation is reestablished, mining areas are susceptible to erosion. Introduction of sediment into a stream can cause local aggradation (filling of the stream channel), thereby discupting channel equilibrium and causing instability of the stream. When the stream channel readjusts in an attempt to reach stable conditions, the entire watershed can be affected.

Mining also affects the ground-water system in the Powder River structural basin in Wyoming. During mining, ground-water levels decline in the vicinity of the mine as a result of mine dewatering. This water commonly is used for dust control. The extent of water-level declines caused by mine dewatering and pumping for mine supplies is dependent on such things as aquifer geometry, aquifer properties, and the rate and length of time the mine is dewatered. An example of water-level declines in the coal aquifer due to pit dewatering is presented in the progress report of this study (Jordan, Bloyd, and Daddow, 1984).

Hadley and Keefer (1975) use idealized block diagrams as examples to present an in-depth discussion of the potential effects on ground-water levels due to mining in the vicinity of a hypothetical mine in the Gillette, Wyoming, area. Their example indicates that the water table probably will be lowered greatly in the vicinity of the hypothetical mine pit and that the shallow wells in the vicinity of the mine have the potential to become dry.

Effects on the ground-water system can occur after mining operations cease and reclamation is finished, even if ground-water levels in the spoil aquifer return to premining levels. Definitive data are not yet available to determine whether or not postmining recharge rates are or will be greater or less than premining rates. Specific unknowns include the porosity and permeability of the spoil aquifer. The spoil aquifer may have a larger porosity than the coal aquifer, but permeability may be smaller because the spoil aquifer will be more heterogeneous and will not contain the fracture or secondary permeability, which is present within the coal aquifer. The method used to backfill the spoil may affect the aquifer characteristics of the spoil.

Where mining occurs near streams, the interchange between ground water and surface water can be altered. For example, if mining occurs near a stream that was gaining water from ground-water discharge during premining conditions, dewatering of an aquifer during mining could cause a reversal of ground-water flow. Then, rather than the stream gaining water from the aquifer, it would lose water to the aquifer. A decrease in streamflow could have a substantial effect on aquatic life in the stream as well as on vegetation adjacent to the stream. Water rights also could be affected. 
The potential exists for effects on surface-water and ground-water quality both during mining and after reclamation. The concentration of dissolved solids in streams downstream from mining areas probably will increase as a result of contact with surface material which contains soluble constituents and as a result of ground-water discharge from spoil areas. Principal effects on ground-water quality probably will occur after mining and reclamation cease. During mining, pit dewatering will cause local ground-water-flow patterns to be towards the mined area. Water-quality changes in nearby aquifers may occur if water of different quality moves into the area. After reclamation, contaminants from the leaching of the mine spoil could affect the quality of water in nearby aquifers and in surface waters that receive groundwater discharge.

Lowry, Wilson, and others (in press, p. 6) state: "Although infiltration, runoff, and aquifer properties can be engineered in a variety of ways, the most likely effect of reclamation will be to inset into the existing hydrologic system a unit having completely different hydrologic properties. The changes could be beneficial or detrimental, or beneficial to some and detrimental to others. For example, if infiltration were increased, less runoff would flow to streams. During intervals of low flow, this decrease could have an adverse effect on downstream users; during floods the decrease could lessen the possibility of flooding and could benefit downstream landowners."

\section{Geologic Setting}

The shallow geologic units, which were of significant interest in this study, are defined as those units stratigraphically above the Lance Formation of Late Cretaceous age. The geologic units include the Fort Union Formation of Paleocene age, the Wasatch Formation of Eocene age, and alluvium of Pleistocene and Holocene age. The outcrop areas of the units are shown in figure 3.

The Fort Union Formation consists of the Tullock, Lebo Shale, and Tongue River Members in ascending order. The Tullock Member is composed of interbedded medium- to light-gray shale, light-gray fine-grained sandstone and siltstone and thin coal beds that grade upward into light-gray sandy or silty shale and locally resistant sandstone. The Lebo Shale Member is predominantly dark shale and concretionary sandstone with siltsone, and locally thin coal beds. The Tongue River Member consists of light-yellow to light-gray fine- to medium-grained thick-bedded to locally massive cross-bedded and lenticular sandstone and siltsone interbedded with gray and black shale. Many thick and laterally persistent coal beds are present. However, the only major coal bed in the Tongue River Member that is presently (1982) mined is the Wyodak coal bed, which is referred to in this report as the Wyodak-Anderson coal bed. Clinker, which consists of fractured shale, siltstone, and sandstone that have been baked by the burning of underlying coal beds, occurs near the coal outcrops (Lewis and Hotchkiss, 1981; Love and Christiansen, 1985).

The Wasatch Formation consists of brownish-gray fine- to coarse-grained lenticular sandstone, interbedded with shale and coal. Coal beds in the lower part as thick and as laterally widespread as in the Tongue River Member of the Fort Union Formation occur in the Wasatch. Clinker deposits also occur near the coal outcrops (Lewis and Hotchkiss, 1981; Love and Christiansen, 1985). 


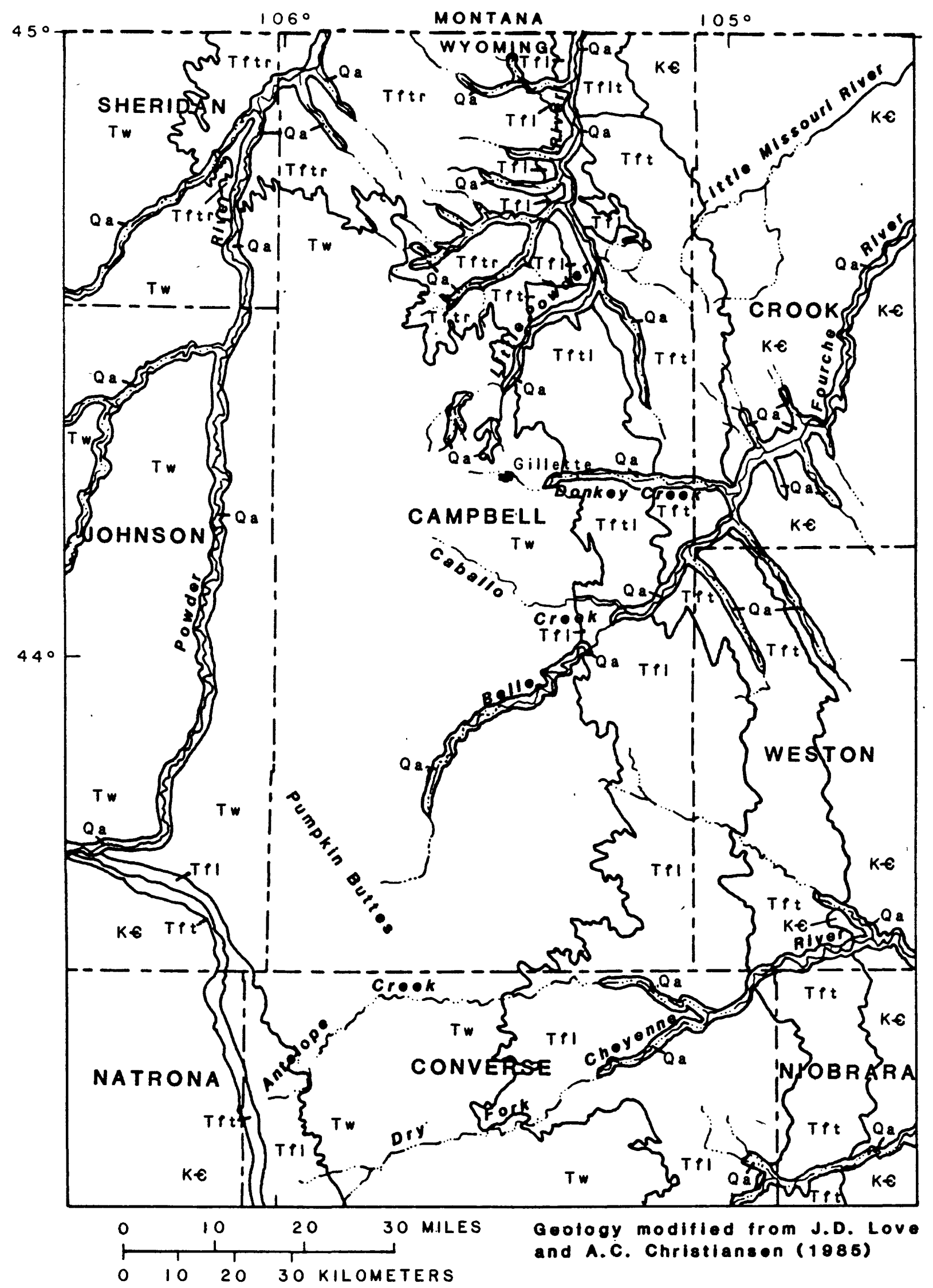

Figure 3.--Surficial geology. 
The alluvium consists of unconsolidated deposits of gravel, sand, and silt. Generally fine to medium grained, the alluvial deposits in the valleys of the Belle Fourche and Little Powder Rivers may be coarser grained (Hodson and others, 1973).

\section{Previous Studies}

A narration about the Powder River structural basin is found in the Wyoming Geological Association 13th Annual Field Conference Guidebook (Wyoming Geological Association Guidebook Committee, 1958). The guidebook contains the geologic history of the area, the stratigraphy of the underlying rocks, the economic importance of the mineral resources, and a general bibliography.

A hydrologic study of the area by Hodson and others (1973) describes the general geology, availability of ground water, chemical quality of the ground water, and streamflow characteristics. Breckenridge and others (1974) provide a synoptic view of the geology, hydrology, land use, and mineral resources of the area.

Koch and others (1982) investigated the regional effects of surface mining on the ground-water system in the Powder River structural basin. This investigation, funded by the U.S. Bureau of Mines, used computer-based models to simulate ground-water flow, surface-water flow, and water quality.

A comprehensive hydrologic report about the area by the U.S. Geological Survey (Lowry, Wilson, and others, in press) is one of a series of coal-area reports for the country, designed to provide a broad overview of all aspects of hydrology to persons interested in coal mining.

\section{EXPLANATION}

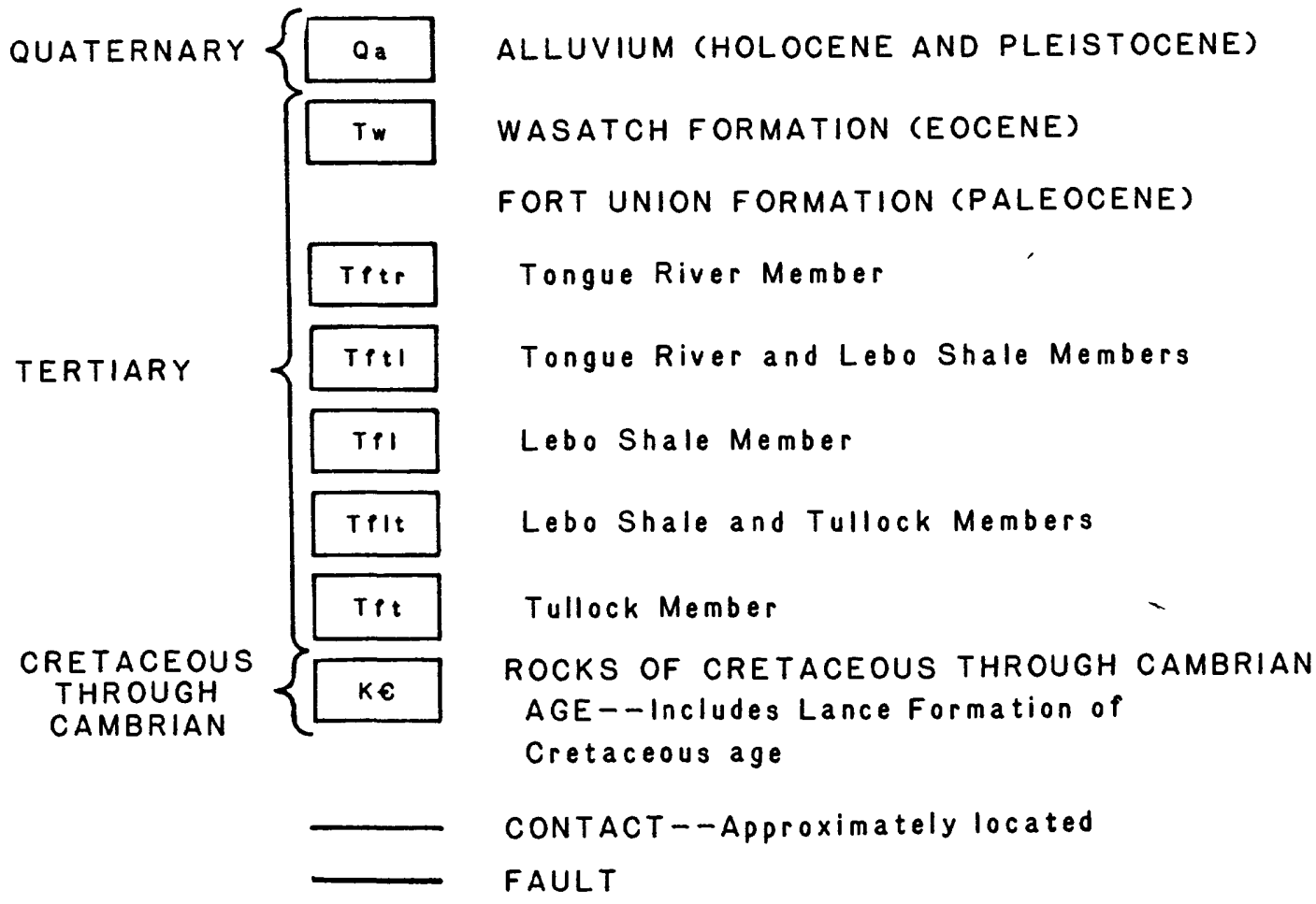

Figure 3.--Continued. 


\section{Acknowledgments}

The authors express their gratitude to Christopher D. Lidstone and Kathy M. Ogle of the Wyoming Department of Environmental Quality (1983) for their assistance in making the data as readily available as possible and in sharing their extensive knowledge of mining activities in the study area. Hsiu-Hsiung Chen, Stanley A. Druse, Kent C. Glover, Robert A. Pettijohn, and Bruce H. Ringen of the U.S. Geological Survey also contributed to this study and report.

\section{DESCRIPTION OF THE BELLE FOURCHE RIVER BASIN}

\section{Climate}

The Belle Fourche River basin has a semiarid temperate climate and has no land features that produce any significant orographic effects. The National Weather Service collects climatological data at several sites in the area, and long-term data (30-year averages) are available for the area.

Average annual precipitation in the Belle Fourche River basin ranges from 12 to $14 \mathrm{in}$. and generally occurs as snowfall during late fall through early spring. During the remaining months, precipitation is mostly rainfall and generally occurs over a large area, with light showers, or occasional intense thunderstorms. The precipitation map (fig. 4) denotes a decrease in precipitation in the southeasterly direction across the area. The monthly distribution of precipitation at the long-term climatological stations is listed in table 2; the station locations are shown in figure 4.

Temperatures in the Belle Fourche River basin range from $-40{ }^{\circ} \mathrm{F}$ during the winter to $100^{\circ} \mathrm{F}$ during the summer. Average monthly temperatures at the long-term stations are listed in table 3.

Wind significantly affects the climate of the area; westerly winds prevail throughout this part of Wyoming. Wind velocity averages about $13 \mathrm{mi} / \mathrm{h}$ annually, varying from $16 \mathrm{mi} / \mathrm{h}$ during November through April to an average of $10 \mathrm{mi} / \mathrm{h}$ during July and August. Daytime winds generally are stronger than nighttime winds. Occasional storms cause brief periods with wind gusts greater than $75 \mathrm{mi} / \mathrm{h}$.

\section{Geology}

The principal geologic units exposed in the Belle Fourche River basin are the Lance Formation, the Fort Union Formation, the Wasatch Formation, and the alluvium (fig. 3). The alluvium in the basin is derived locally and is predominantly fine grained. The maximum thickness of the alluvium of the Belle Fourche River is $33 \mathrm{ft}$ (W.G. Hodson, U.S. Geological Survey, written commun., 1975).

Most of the drainage system of the Belle Fourche River occurs on the Wasatch Formation. Alluvium occurs along most of the mainstem of the river; in places, the river flows across the Wasatch and outcrops of the Lebo Shale and Tullock Members of the Fort Union Formation. 


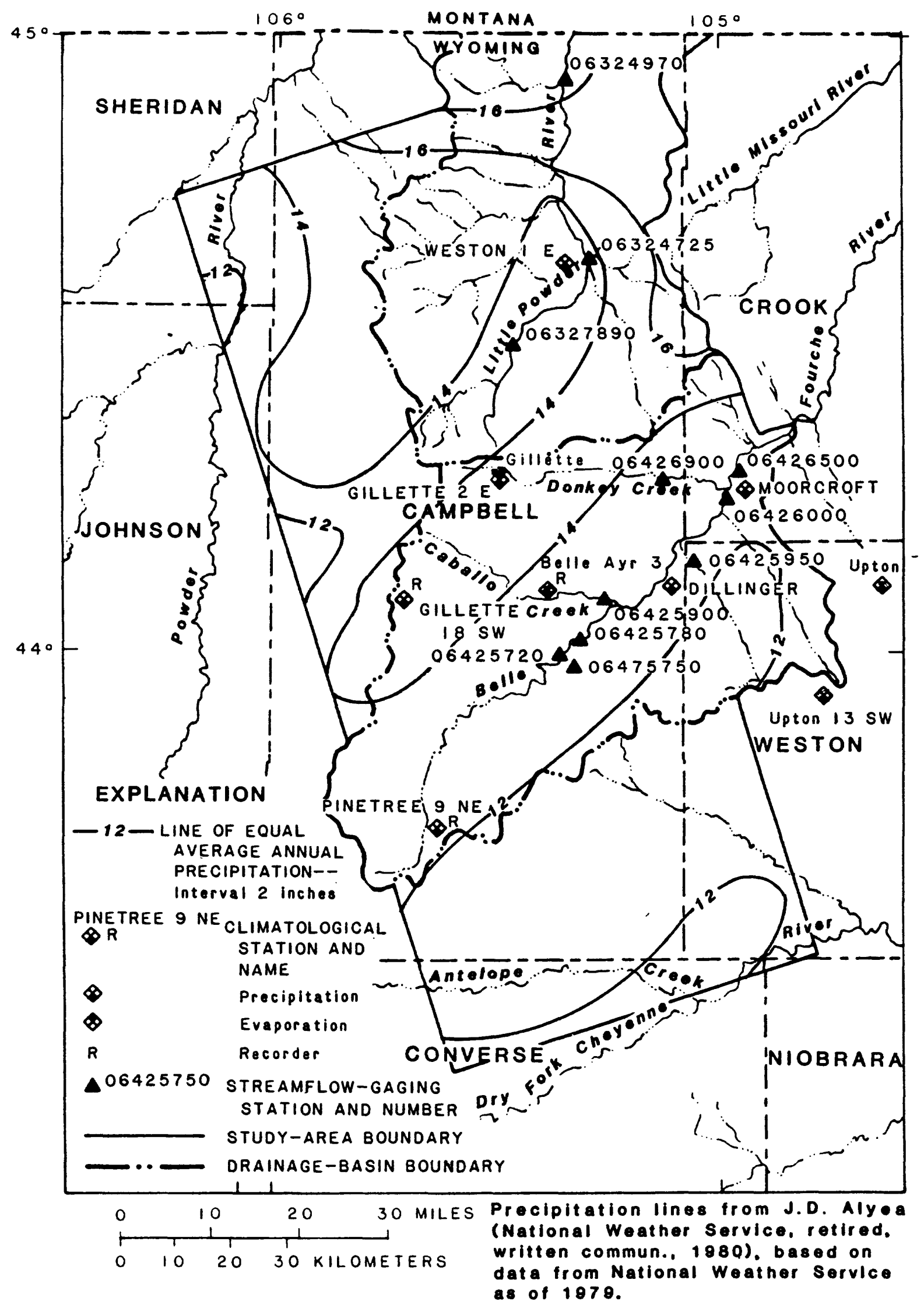

Figure 4.--Average annual precipitation and location of climatological and streamflow stations. 

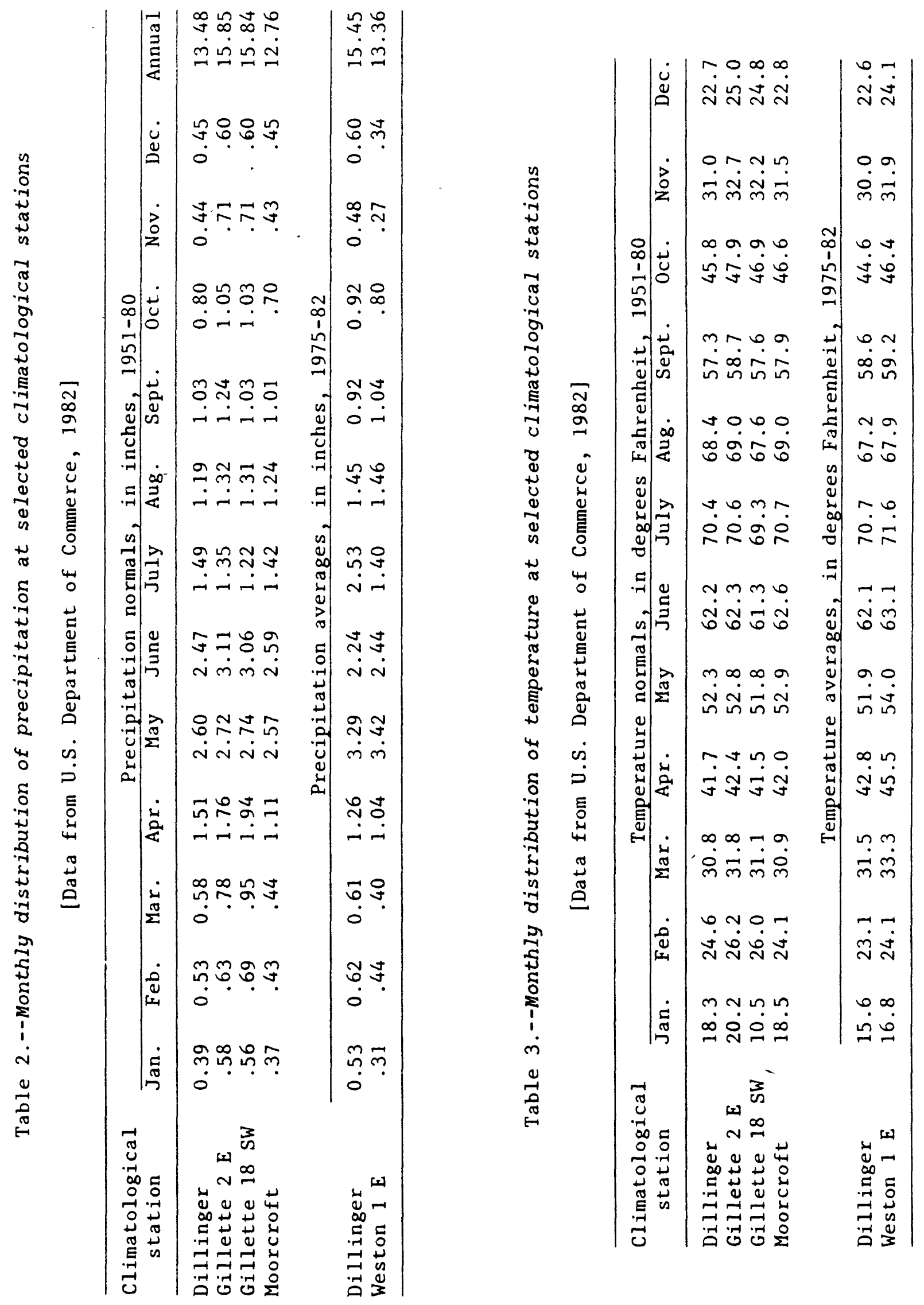


\section{Soil Characteristics and Vegetation}

Soil characteristics are variable in the Belle Fourche River basin (Young and Singleton, 1977). The erodibility of soils is classified as moderate with the exception of the eastern one-third of the basin, which is classified as low to moderate. The soils generally are fine grained, contain little organic matter, and are alkaline. Clay content generally is less than 35 percent. Runoff potential for most of the basin is moderately high. Alluvial material with medium erodibility and moderately low to moderately high runoff potential is found along the Belle Fourche River.

Vegetation in the area is classified by Young and Singleton $(1977$, p. 2) as being the type that typically occurs in the 10- to 14-in. precipitation zone. The woodland and grassland species comprising the natural vegetation in the basin are listed in table 4. Agricultural use of the land is principally for livestock grazing; little land is tilled. Hay fields are located in valleys where they can be irrigated from nearby streams.

Table 4.--Natural vegetation in study area

[Data from Young and Singleton, 1977]

\begin{tabular}{|c|c|}
\hline \multicolumn{2}{|c|}{$\begin{array}{l}\text { Precipitation } \\
\end{array}$} \\
\hline 15 to 17 inches per yea & 10 to 14 inches per year \\
\hline \multicolumn{2}{|c|}{ Woodland species } \\
\hline $\begin{array}{l}\text { Cottonwood } \\
\text { Juniper } \\
\text { Ponderosa pine }\end{array}$ & Cottonwood on lowland sites \\
\hline \multicolumn{2}{|c|}{ Grassland species } \\
\hline $\begin{array}{l}\text { Western wheatgrass } \\
\text { Prairie sandreed grass } \\
\text { Needleandthread grass } \\
\text { Big sagebrush } \\
\text { Greasewood } \\
\text { Green needlegrass } \\
\text { Little bluestem } \\
\text { Low rabbitbrush }\end{array}$ & $\begin{array}{l}\text { Western wheatgrass } \\
\text { Prairie sandreed grass } \\
\text { Needleandthread grass } \\
\text { Big sagebrush } \\
\text { Greasewood } \\
\text { Blue grama grass }\end{array}$ \\
\hline
\end{tabular}

\section{Streamflow}

Continuous streamflow records have been collected at eight sites in the Belle Fourche River basin (fig. 4). The longest record available is for the Belle Fourche River below Moorcroft (34 water years); all other stations have records of 10 water years or less. Short-term records need to be used with caution because any extreme discharge data, high or low, may cause statistical analysis of the data to be misleading. 


\section{Average Annual Discharge}

Average annual discharge at stations with four or more water years of record are listed in table 5. An analogy of how representative the shorter term records are of a longer term record is illustrated by data shown for the Belle Fourche River below Moorcroft (station 06426500). Average annual discharge for the period of record (water years 1943-70, 1975-82) is $23.1 \mathrm{ft}^{3} / \mathrm{s}$ compared to $31.1 \mathrm{ft}^{3} / \mathrm{s}$ for water years 1975-82. This comparison indicates that streamflow for stations with records for water years 1975-82 may be greater than what normally might be expected. The shorter period includes the 1978 water year, which has been documented as a year when streamflows were considerably greater than normal (Druse and others, 1981). The early 1920's also had many historic floods in the area, which may account for the large average annual discharge for the period of record at Belle Fourche River near Moorcroft (station 0642600).

Keyhole Reservoir, which is about $12 \mathrm{mi}$ northeast of Moorcroft, is the only major reservoir in the area. The reservoir, which is operated by the U.S. Bureau of Reclamation, provides flood control and water for irrigation in Wyoming and South Dakota. Also upstream from Moorcroft are numerous small stock-water and soil-conservation reservoirs.

\section{Flow Duration}

A comparison of flow-duration curves indicates that unit discharge (discharge per square mile) at Donkey Creek is slightly greater than unit discharges at other stations in the Belle Fourche River basin. Flow in Donkey Creek might be affected by discharge from the sewage-treatment plant at Gillette. Flow-duration curves, which were modified to show discharge per square mile, are presented in figure 5 for drainage areas smaller than $500 \mathrm{mi}^{2}$ and in figure 6 for drainage areas larger than $500 \mathrm{mi}^{2}$. The arbitrary division of drainage areas and use of unit discharge provides a basis for comparison of runoff characteristics. Flow-duration curves for the station on the Belle Fourche River below Moorcroft presented for the entire period of record as well as for water years 1975-82, provides a comparison between longer and shorter term records. The duration curves for the Donkey Creek station has a slight flattening in slope at the smaller unit-runoff values. Such flattening indicates the presence of minor surface-water storage or ground-water discharge. However, the overall steep slopes of all curves indicate that flow is mainly from direct runoff of precipitation.

\section{Floodflow}

Peak discharges versus drainage areas for flood peaks in the Belle Fourche River basin are shown in figure 7. The plot includes all peak discharges listed in table 5, miscellaneous peak-discharge measurements listed in Lowham (1976, p. 52, 53, 79), and peak discharges determined at partial-record sites (U.S. Geological Survey, 1977-82). 


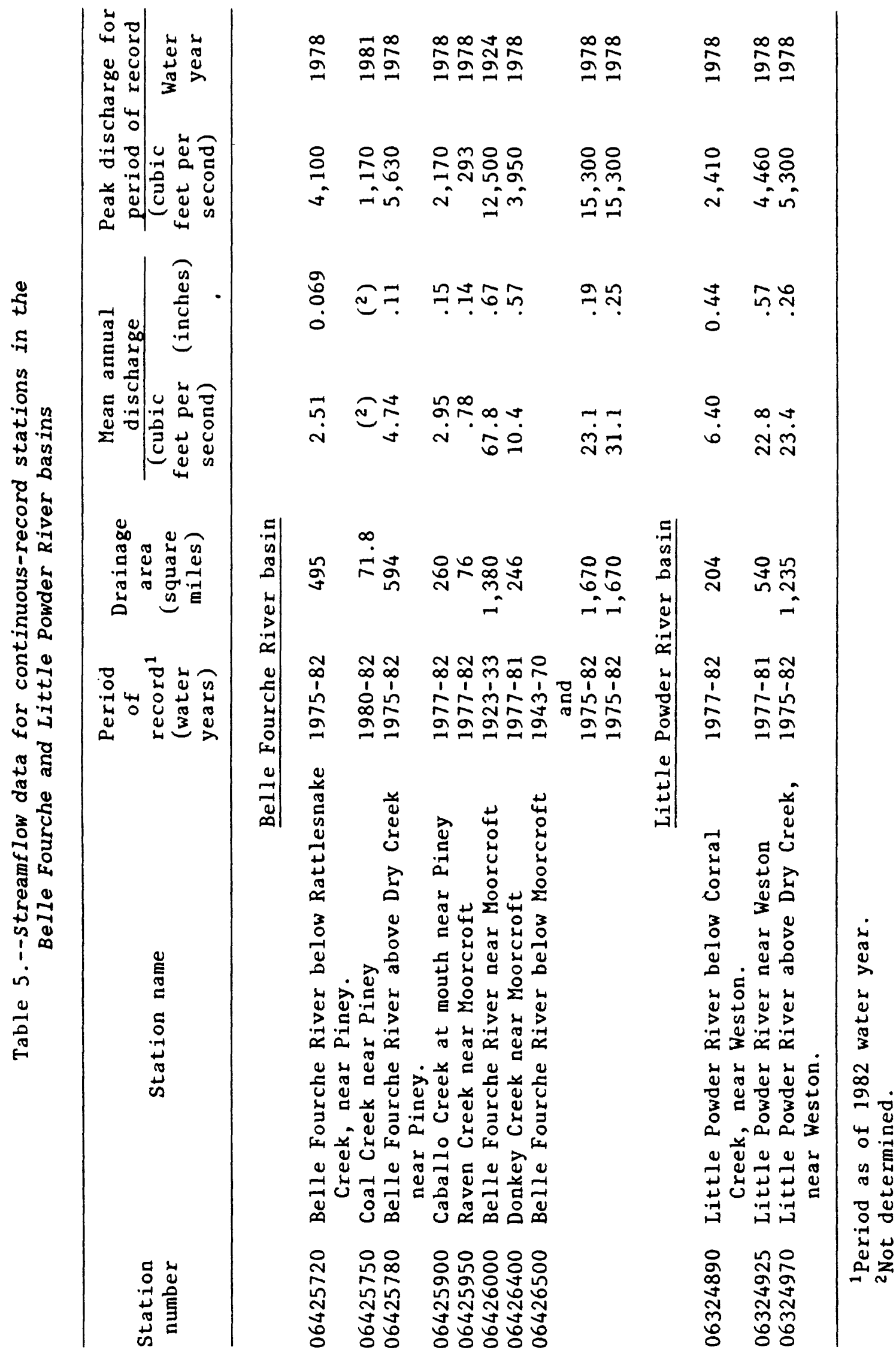




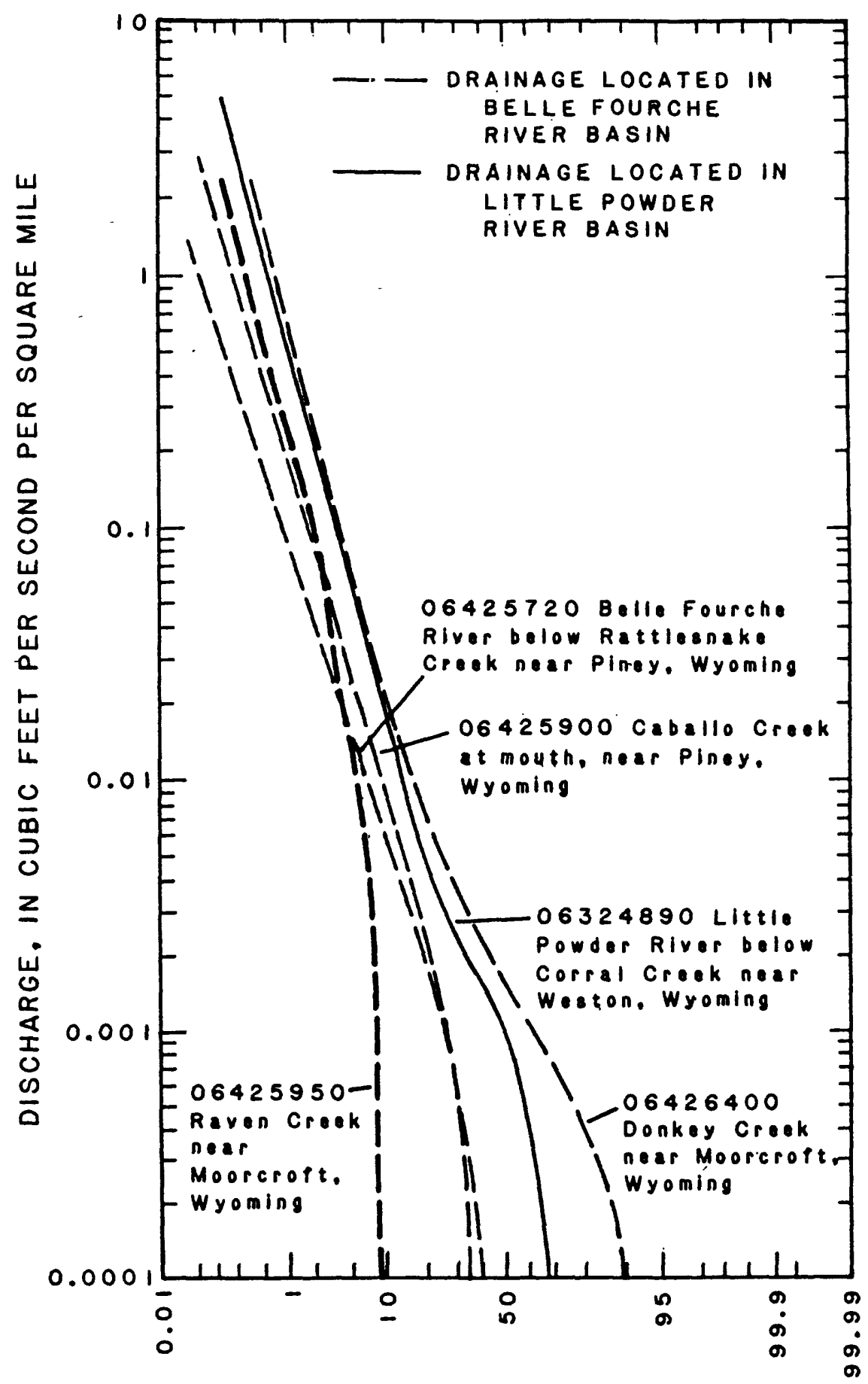

PERCENTAGE OF TIME STREAMFLOW

WAS EQUALED OR EXCEEDED

Figure 5.--Flow-duration curves of unit discharge for drainage areas smaller than 500 square miles. 


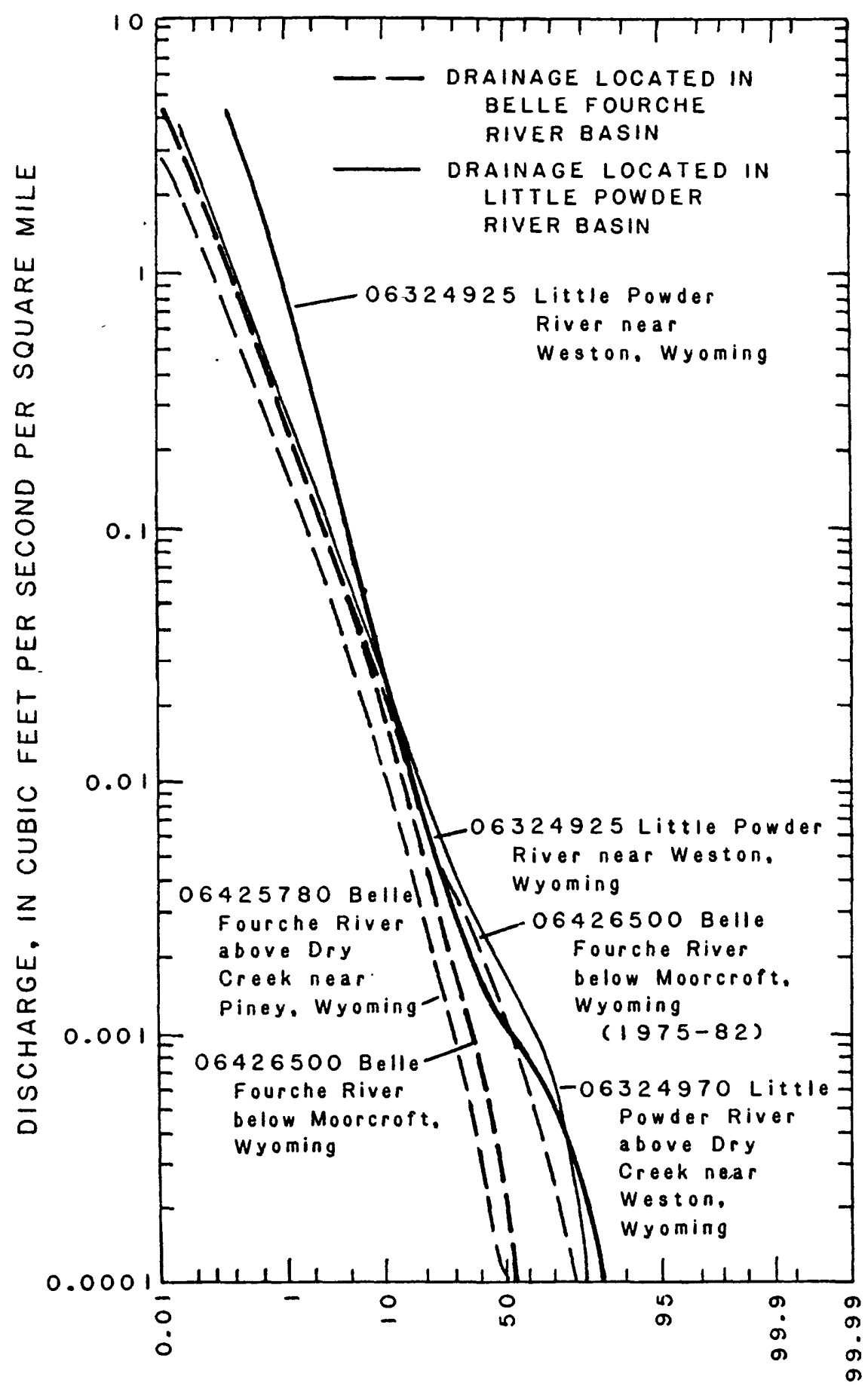

PERCENTAGE OF TIME STREAMFLOW WAS EQUALED OR EXCEEDED

Figure 6.--Flow-duration curves of unit discharge for drainage areas larger than 500 square miles. 

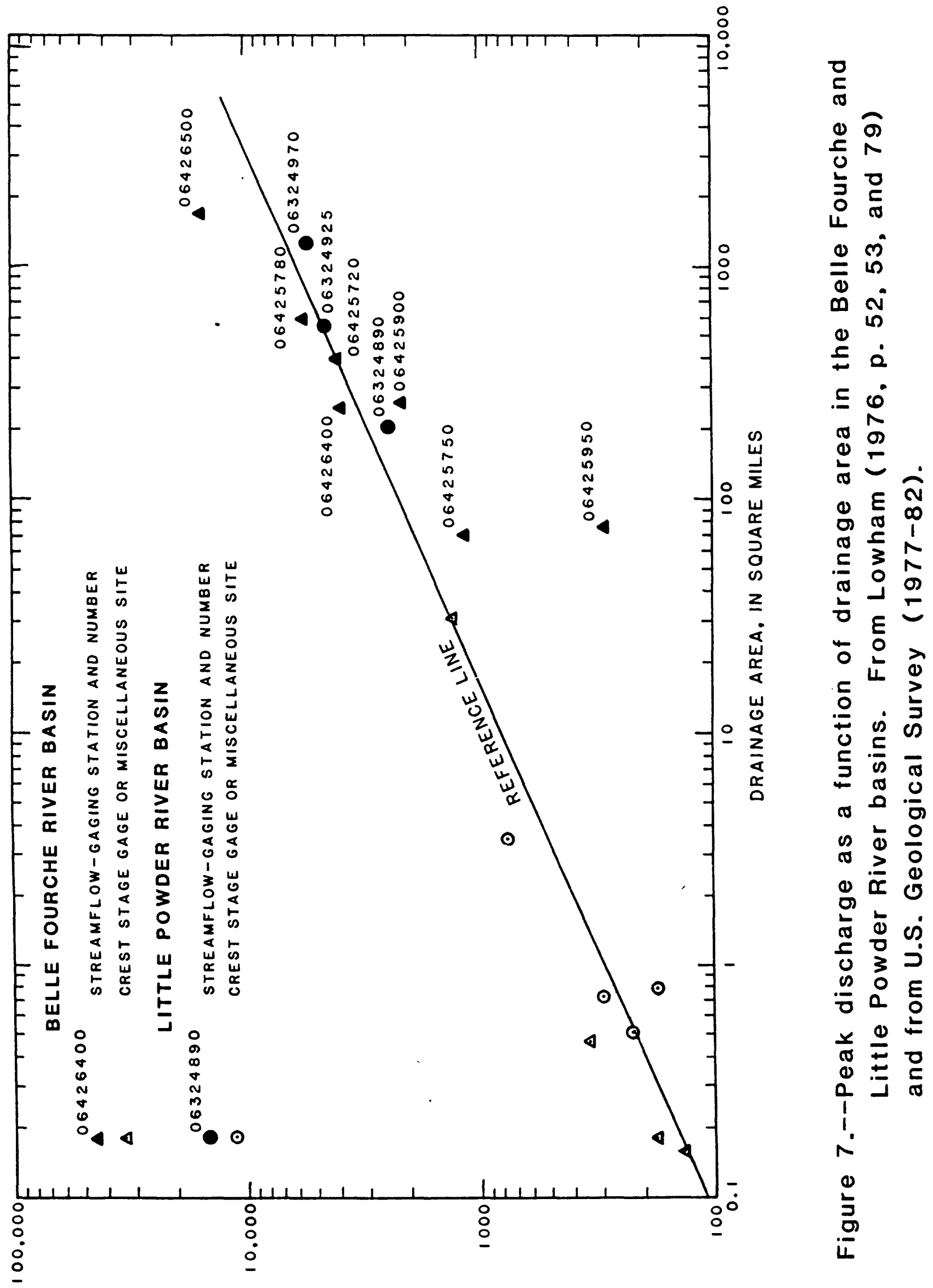

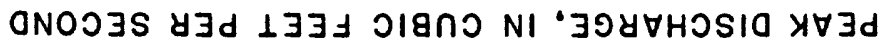




\section{COMPUTER MODEL OF THE SURFACE-WATER HYDROLOGY}

IN THE BELLE FOURCHE RIVER BASIN

In order to determine the effects of mining on the surface-water hydrology in the Powder River structural basin, a computer model of the Belle Fourche River basin was developed. The transferability of the results of the model to the Little Powder River basin will be evaluated. In addition, a better understanding of the surface-water hydrology of a small drainage basin can be gained from the development and application of the model.

Changes in streamflow, dissolved-solids concentration, and sulfate concentration in the Belle Fourche River downstream from all anticipated mining as a result of the cumulative effects of mining and reclamation were addressed. The process used to simulate the hydrology in the Belle Fourche River basin includes the following steps:

1. Identify the problems to be addressed.

2. Select an appropriate model to address the identified problems.

3. Collect and assemble the appropriate data.

4. Calibrate the model for a historical period for which appropriate data were available.

5. Study the sensitivity of the calibrated model to changes in parameter values.

6. Verify the applicability of the calibrated model by applying it to a historical period other than the calibration period.

7. Determine the changes to be made in the land surface by surface coal mining and reclamation and translate those changes into appropriate changes of hydrologic characteristics used in the model.

8. Use the calibrated model to simulate two historical periods for which appropriate data were available to simulate and compare results for the three drainage-basin conditions associated with the following phases of mining operations: (a) Premining, (b) duringmining and reclamation, and (c) postmining and post-reclamation.

The effect of mining on streamflow and selected water-quality characteristics in the Belle Fourche River basin can be predicted using a deterministic distributed-parameter model (rather than a statistical model). The deterministic model uses mathematical formulations of physical processes. The distributed-parameter type is needed for areal variations in hydrologic characteristics used in the model or if only the land surface in part of a basin is altered, both of which are needed for the Belle Fourche River basin.

The Hydrological Simulation Program-Fortran (HSPF) model (Johanson and Kittle, 1983) was used in this study. It is the product of lengthy development, testing and application, beginning with the Stanford Watershed Model (Crawford and Linsley, 1966). Use of the HSPF model is supported and guided by a comprehensive manual (Johanson, Imhoff, and Davis, 1981). The model is versatile and includes numerous options for the display of results.

The HSPF model simulates the water budget of a drainage basin. Beginning with precipitation, it simulates the processes of infiltration, soil-moisture storage, evapotranspiration, surface runoff, and interflow (subsurface lateral flow through soil). Recharge to active and inactive ground-water units is 
simulated by a simplified calculation. Flow is routed through the main stream channel, accounting for in-channel storage and travel time. Flow also can be routed through reservoirs or ponds having single or multiple outlets. The model can simulate snow accumulation and snowmelt if the required additional data for use in the model are available. Sediment erosion and transportation can be simulated, by the processes of detachment from soil by raindrop impact; transportation by surface runoff; erosion by surface runoff; and transportation, deposition, and erosion in main channels.

The concentrations of conservative chemical-quality constituents in streamflow are composed of surface-runoff, interflow, and baseflow components. Surface-runoff contributions can be simulated through the same processes as for sediment, and by the process of accumulation and washoff from the land surface. The contributions from the interflow and baseflow components of streamflow can be simulated in the model by a constant value for each.

\section{Data Preparation}

The Belle Fourche River drainage area, upstream from the inlet to Keyhole Reservoir at U.S. Highway $14\left(1,720 \mathrm{mi}^{2}\right)$, initially was divided into 12 land segments (fig. 8). The division into land segments was done to account for areal variations in precipitation, land and channel characteristics, and locations of streamflow-gaging stations used in calibration of the model. Generally, divisions were made along drainage boundaries. Between parts of land segments 1,2 , and 3 , and between segments 6 and 7 , artificial boundaries were used to better apply precipitation data. Stream reaches of the Belle Fourche River, Caballo Creek, and Donkey Creek were selected for routing of main-channel flow. Land segments 4, 5, 7, and 11 were divided into nonpermit and mine-permit areas. The mine-permit areas were further subdivided into unmined, disturbed, and reclaimed areas (not detailed on fig. 8) to coincide with each time period modeled. Simulated sedimentation ponds were included for the disturbed and reclaimed areas.

The location of streamflow-gaging stations and climatological stations also are shown in figure 8. Data from the National Weather Service evaporation pan at Gillette $2 \mathrm{E}$ were used for estimating potential evapotranspiration for the entire basin. Where precipitation data were missing, the data were estimated from data at nearby stations. Data from the Upton and Upton $13 \mathrm{SW}$ stations were not used directly in the model, but were used for estimating missing data at the Moorcroft station.

Because runoff and streamflow are greatly affected by precipitation intensity, a time step of 1 hour was chosen for the surface-water model. Hourly rainfall data were available at Belle Ayr Mine station Belle Ayr-3 and National Weather Service stations Pine Tree $9 \mathrm{NE}$, Gillette $18 \mathrm{SW}$, and for some periods at Moorcroft. To provide better coverage of rainfall for the model, the daily rainfall at Gillette $2 \mathrm{E}$ and Dillinger were distributed hourly based on the hourly data at Gillette $18 \mathrm{SW}$, Belle Ayr-3, and Moorcroft (when available). When hourly data were not available for Moorcroft, the measured or estimated daily rainfall was distributed hourly based on the hourly data at Belle Ayr-3 and Osage (about $14 \mathrm{mi}$ southeast of Upton). 


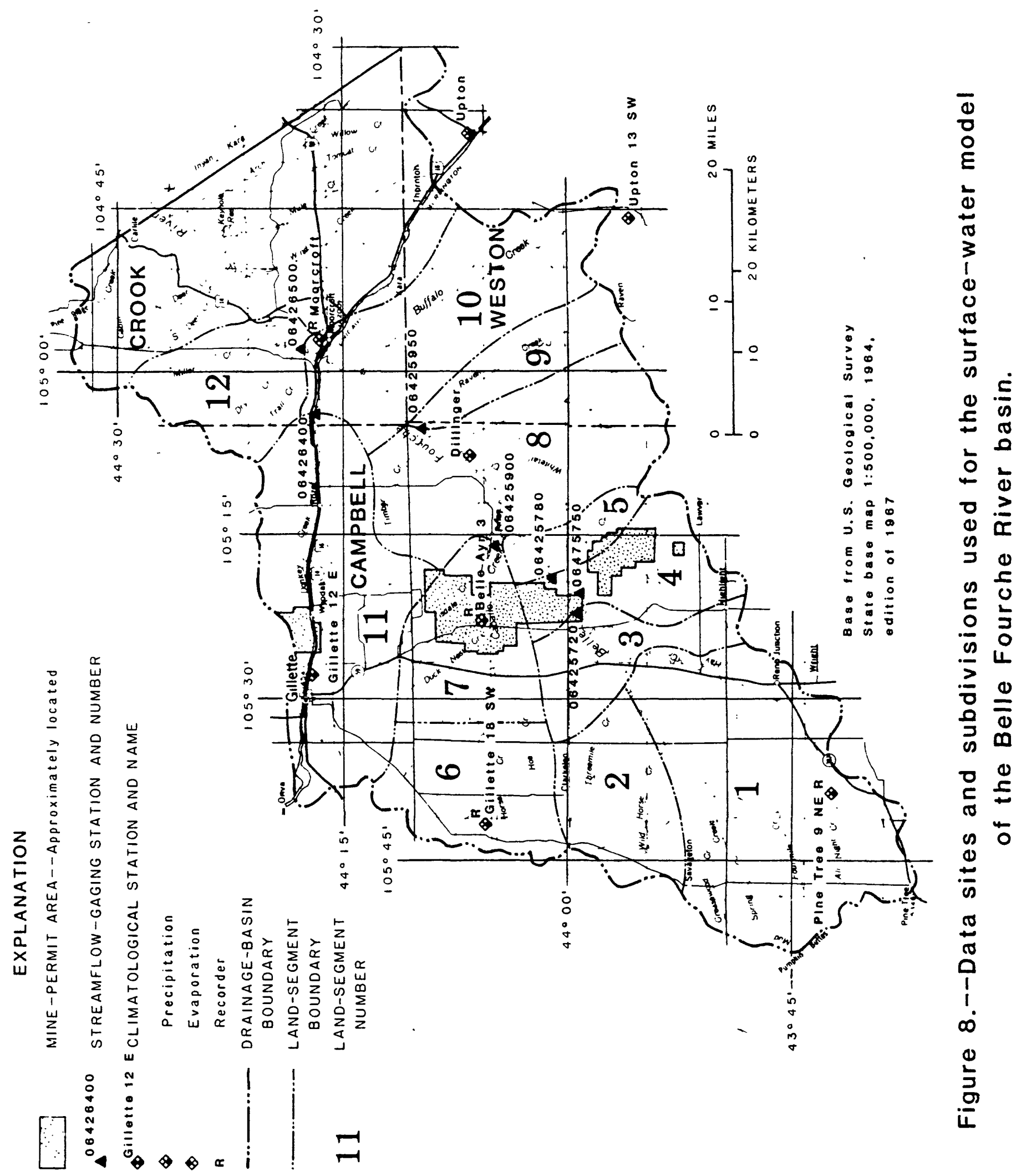


Topographic characteristics used in the model are the area of each land segment, the average length of overland-flow path, and the average slope of overland-flow path for each land segment. For unmined areas and the premining condition in mine areas, these characteristics were measured from U.S. Geological Survey topographic maps (scale 1:24,000). For the during-mining condition in mined areas, average length and slope were roughly estimated from the combination of nearly level pit-floor areas and the indeterminate topography of spoil piles. For the postmining condition in mined areas, the average length and slope, measured from five postmining topography maps from the Wyoming Department of Environmental Quality mine permits, were assumed to be representative of mines in all the land segments.

\section{Calibration}

Calibration of a surface-water model ideally should be based on at least 3 years of simulation to evaluate the hydrologic characteristics used in the model under a variety of climatic, soil-moisture, and water-quality conditions (A.S. Donigan, Jr., J.C. Imhoff, B.R. Bicknell, and J.L. Kittle, AndersonNichols Co., written commun., 1982). However, data for a 3-year calibration period in the study area were not readily available.

May and June of 1978, 1980, and 1982 were chosen for calibration, verification, and prediction. Sufficient precipitation and streamflow data were available for these periods for the application of the model. Also, the precipitation during these periods was generally widespread and relatively uniform areally, so errors associated with nonrepresentative measured precipitation were minimal. Precipitation and streamflow values for the selected time periods are listed in table 6 .

May and June 1978, which had the greatest range of hydrologic conditions, was most useful for determining representative values for hydrologic characteristics used in the model. Even though the early May precipitation included about 20 percent snow, it melted rapidly, and thus the effect on the volume of runoff was not significantly different from that which would have been produced from 100 percent rainfall. Data for April 1978 also included snow, but were used only to decrease the effect of the initial values for moisture storage during the calibration runs. However, only the May and June simulation results were compared with measured data in the calibration process.

The time period selected for calibration of the model represents the premining condition; although mining had started by 1978 , less than 0.2 percent of the drainage basin had been disturbed. As discussed in the data-preparation section, the premining values of area, average length of overland-flow path and average slope of overland-flow path for each land segment were determined from topographic maps. Although these values may contain some error, they were not adjusted during the calibration process.

Initial estimates of infiltration capacity were based on information in Young and Singleton (1977), in Rank1 (1982) for undisturbed areas, and in Gifford (1981) for reclaimed areas. Initial estimates of the water-storage capacity of the upper soil zone and the lower soil zone were based on descriptions of the soils by Young and Singleton (1977) and results of the earlier 


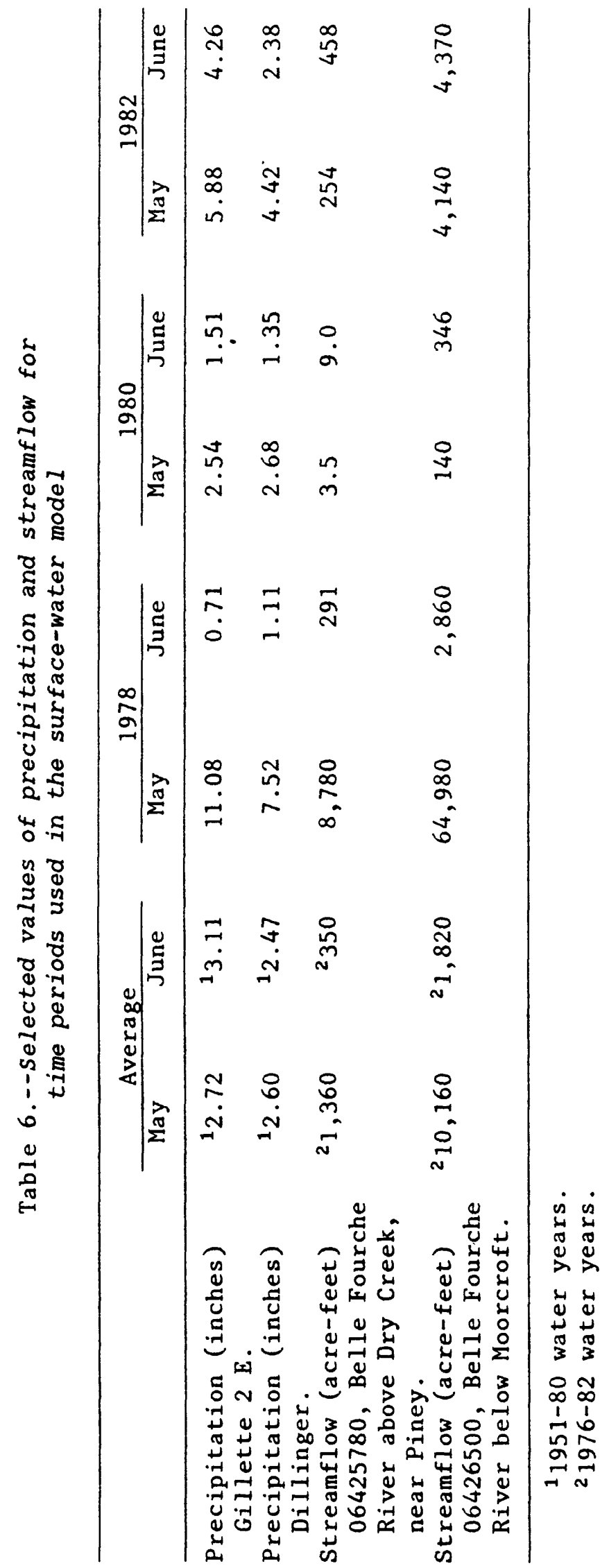


Caballo Creek model. Estimates of deep-aquifer recharge, the fraction of recharge from the lower soil zone that percolates to a deep aquifer, also were based on results of the Caballo Creek model. The base-flow recession constant represents the rate of decrease in outflow from ground-water storage. Estimates were based on hydrographs of base-flow recessions.

Initial estimates of the chemical-quality constituents were based on water-quality data in the files of the U.S. Geological Survey. The dissolvedsolids and sulfate concentrations in the ground-water contribution were estimated from samples collected during low flow when ground water was the only source of streamflow. The dissolved-solids and sulfate concentrations in the interflow contribution were estimated from samples collected during medium flow. Many samples collected during high flow had small concentrations of dissolved solids and sulfate. Because difficulties resulted when small concentrations of dissolved-solids and sulfate were entered into the model, the model initially was set to omit calculations of dissolved-solids and sulfate concentrations in surface runoff.

The initial estimates of hydrologic characteristics used in the model resulted in simulated flows and concentrations that differed considerably from those measured. Adjustment of the hydrologic characteristics during calibration of the model was guided by the effect each characteristic has on the simulated flow volume, shape of different parts of the hydrograph, or dissolved-solids or sulfate concentration. For example, in working with the model it became obvious that the base-flow recession constant determines the slope of the recession of the simulated hydrograph and also has some effect on the flow volume. Also, deep-aquifer recharge has a large effect on the flow volume and also on the dissolved-solids and sulfate concentrations.

The measured dissolved-solids and sulfate data were particularly helpful in the calibration process. The model calculations of flow based on the initial estimates of hydrologic characteristics resulted in very little calculated surface runoff or interflow and nearly constant concentrations of dissolved solids and sulfate. Adjustments were made, particularly a decrease of infiltration capacity, to calculate more surface runoff and interflow and, therefore, a greater, more realistic range of dissolyed-solids and sulfate concentrations.

The values for hydrologic characteristics which resulted after adjustment in the calibration process are listed in table 7 . The results of the model calculations using the adjusted characteristics are compared with measured values in table 8 . Simulated streamflow volume for the calibration period at the downstream station, Belle Fourche River below Moorcroft, is about 6 percent less than the measured flow. The simulated and measured daily values of concentrations of dissolved solids and sulfate differed by 18 and 35 percent, respectively. The differences for dissolved-solids and sulfate concentrations probably result from inadequate calibration of variables that affect the contribution of ground-water discharge and overland runoff to total streamflow and the short-term data base used for calibration. Some indications of the effects of calibration errors on evaluation of effects of mining on hydrology are given in the section on model applications and results. Typical hydrographs of simulated and measured streamflow are shown in figures 9 and 10 . 


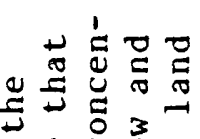

- 웡 3

$\because 0$ 皮

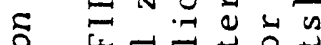

- 2 之.

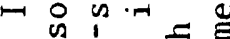

$\therefore$ ज $\frac{1}{0}$ ह

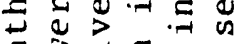

¿ 070 잉

$3 \rightarrow$ un

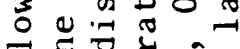

H

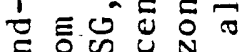

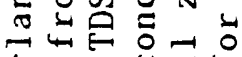

(1) 0.7 $>\infty$ 0 茴 แथ U ᄂ $E$ is 3 合范

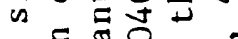
๑.

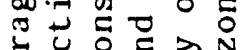
\& 0 U 0 ये $=-\overrightarrow{4}=$

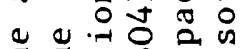
$\equiv \equiv$ in o 0

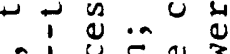
× $\supset$ o

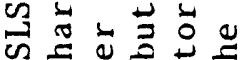
范 Е山

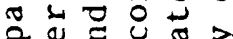
24

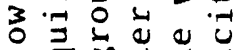
च $\sigma^{\circ} \underset{\pi}{\pi}$ 1 $103-0$

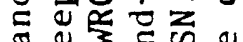
웜 (1)

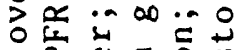

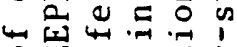

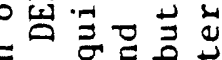

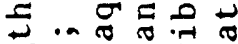
公州牙

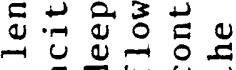
ช อ 車

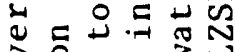
300 थ ع $\pm 0 .-100$

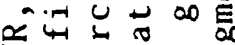
号望焉

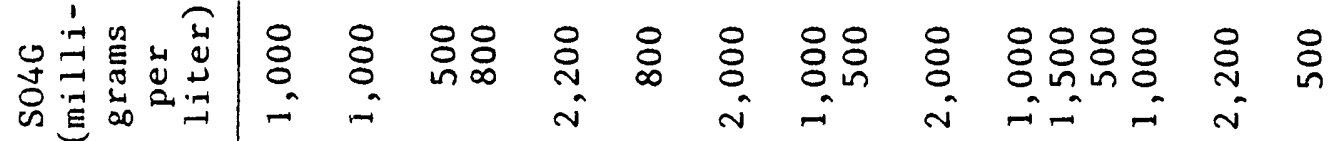
$-\stackrel{1}{=} \cong$

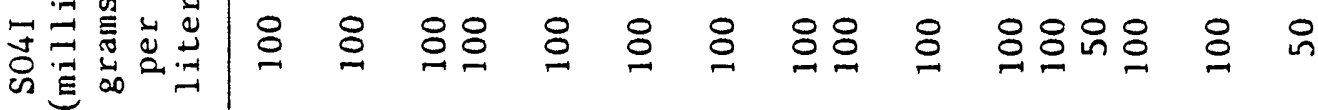

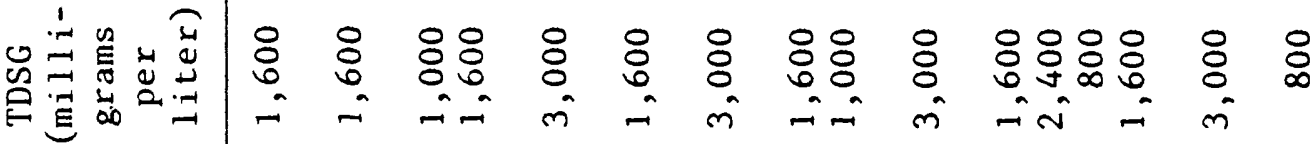

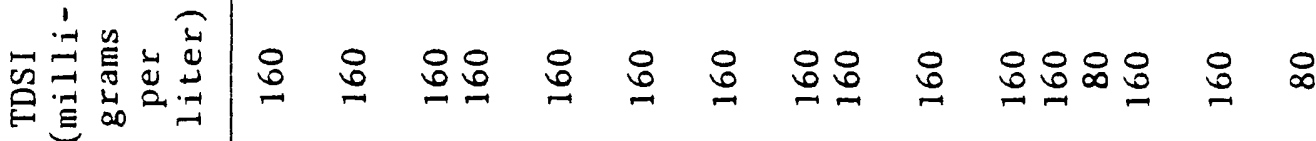

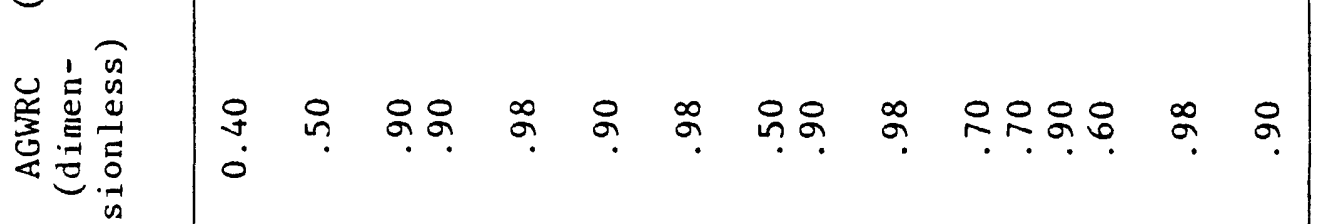

a, is 댐 ज 幽罢 멤 式

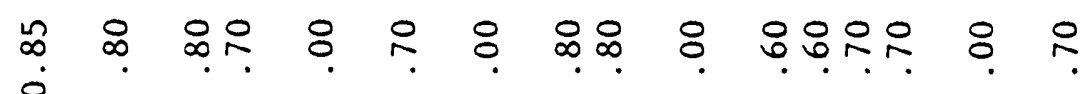
0.

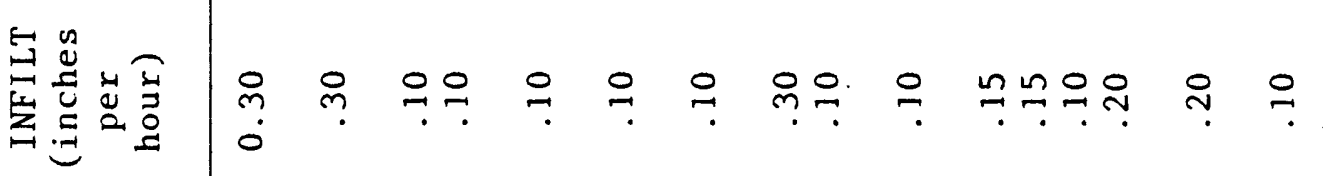

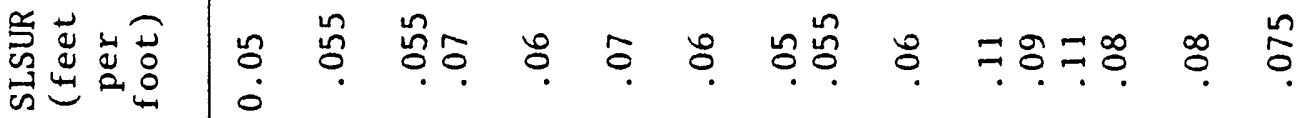

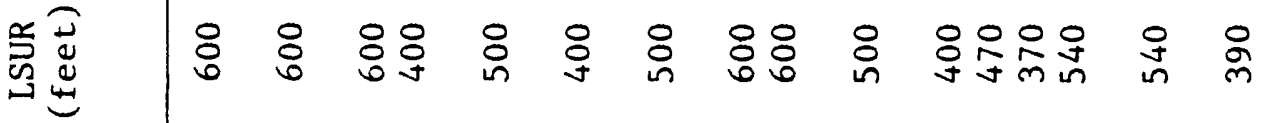

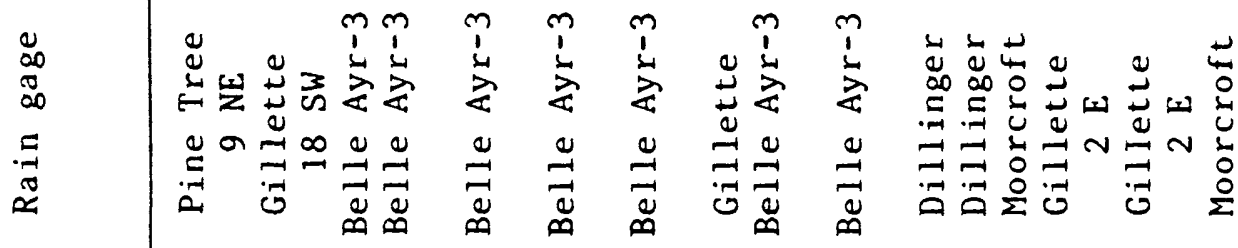

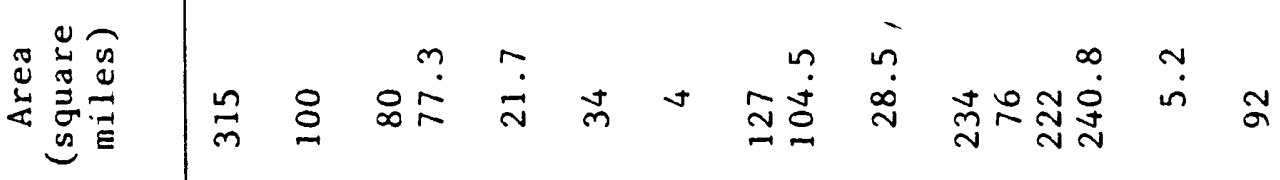
in $-N$ m 


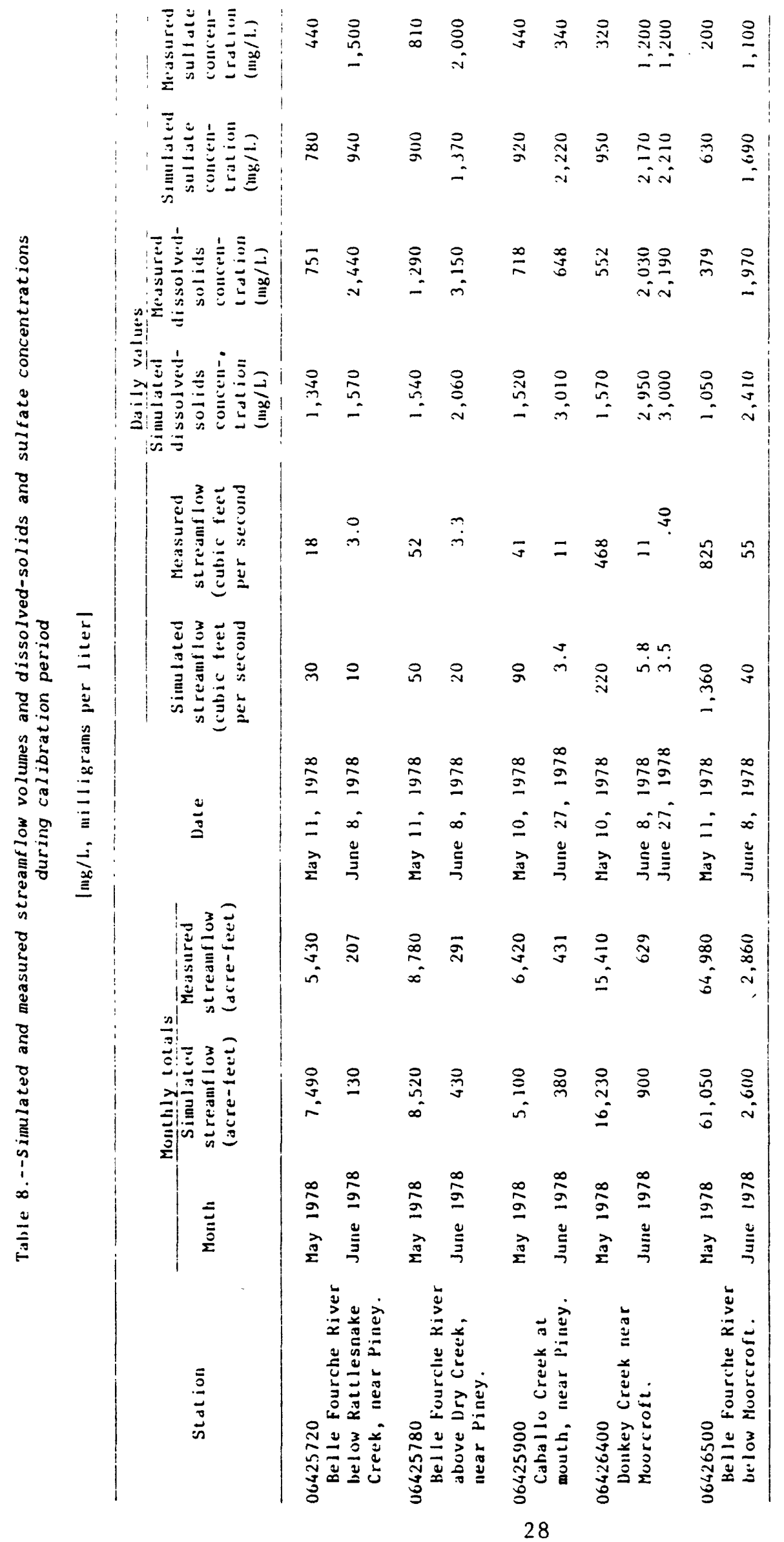




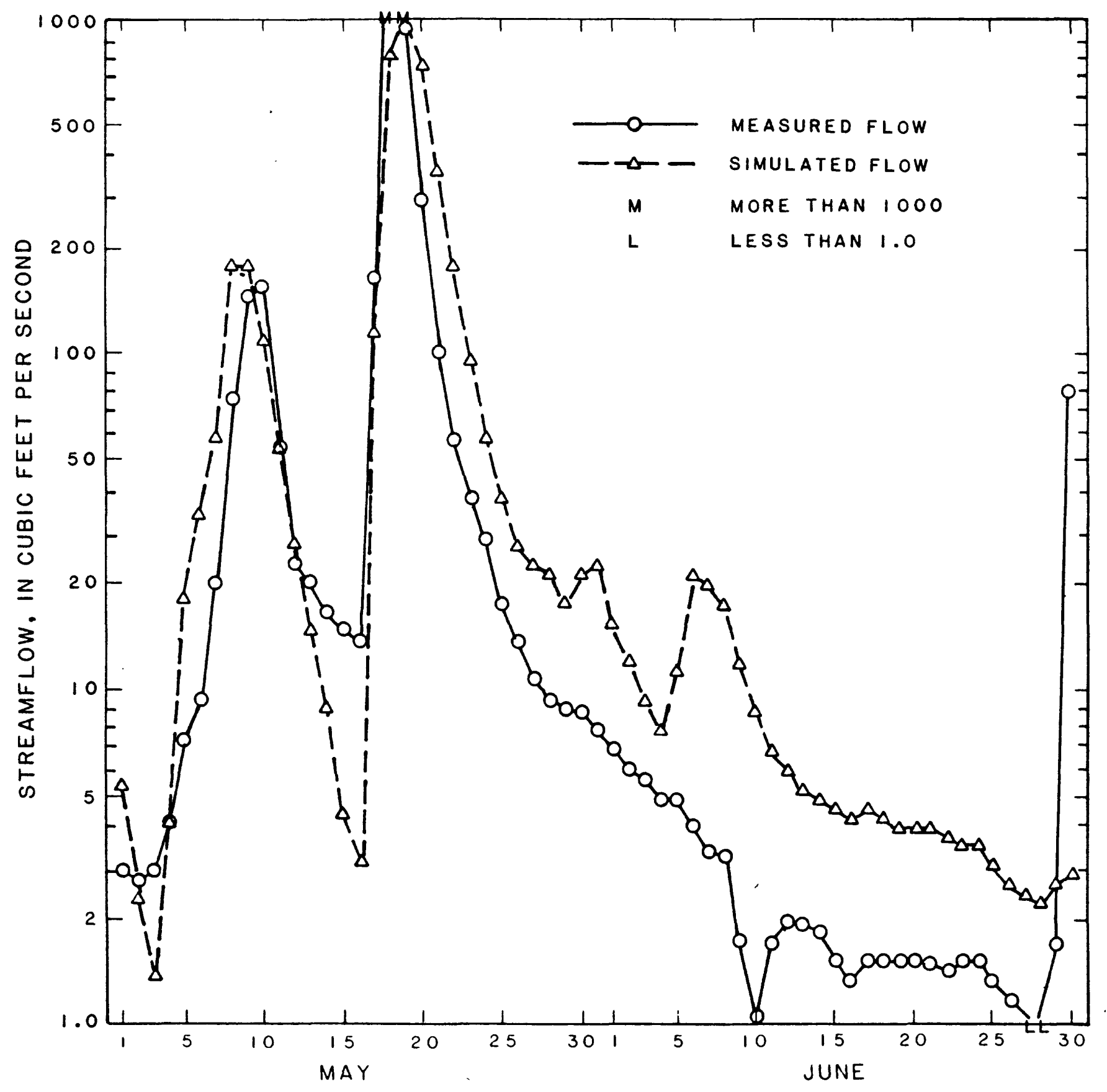

Figure 9.--Measured and simulated streamflow at station 06425780 Belle Fourche River above Dry Creek, near Piney, Wyoming, May-June 1978. 


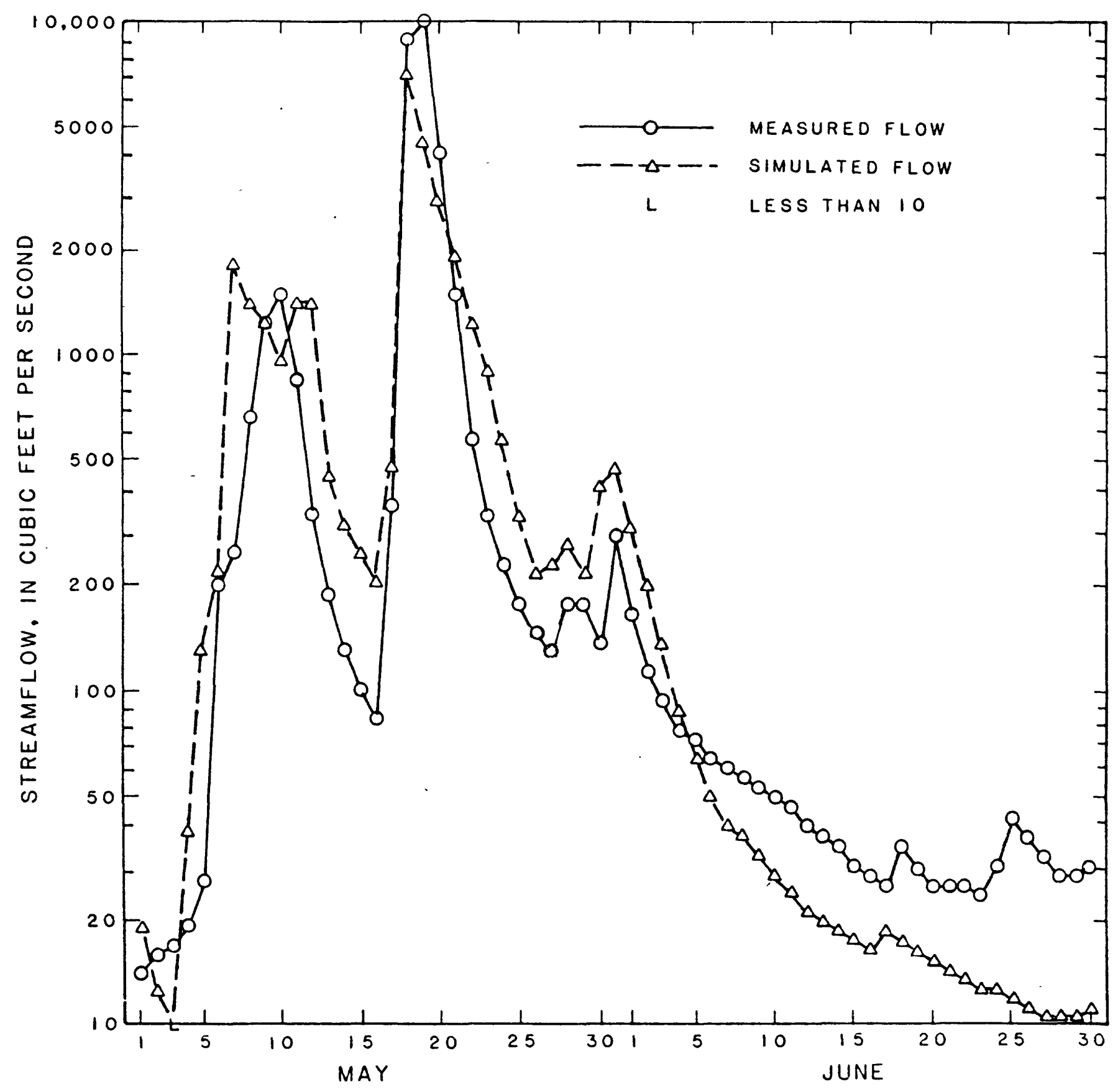

Figure 10.--Measured and simulated streamflow at station 06426500 Belle Fourche River below Moorcroft, Wyoming, May-June 1982. 


\section{Verification}

Verification of a calibrated model is desirable to provide a better indication of the reliability of results. The desirable situation would be to have 3 or more years of measured data representing a range of conditions for calibration and a period of equal length available for verification. The results for a short period of verification could be misleading by falsely indicating a biased calibration or by indicating better accuracy than actually achieved. In the present case, only three 2-month periods were available; the period having the greatest range of conditions was used for calibration and one of the other periods was used for verification. May and June 1982 was chosen for model verification. Typical results are shown in figure 11.

The simulated peak flows were similar to the measured peak flows for the verification period, but the simulated daily flow values were larger than the measured flow values for almost all days of the simulation period (fig. 11). Some of the lack of agreement could be the result of inaccurate estimation of missing rainfall data during 1982 for some of the stations and the result of using only 1 month to establish initial soil-moisture conditions. The agreement between simulated dissolved-solids and sulfate concentrations for the verification period was similar to that for the calibration period. Information about the effects of model bias on the evaluation of the effects of mining is provided later.

\section{Sensitivity Analysis}

Although a thorough sensitivity analysis was beyond the scope of this study, additional simulations were made to indicate model sensitivity to variations in hydrologic characteristics used in the model. If large changes in a particular hydrologic characteristic result in relatively large changes in model-calculated values, the model is said to be sensitive to that hydrologic characteristic. Conversely, if large changes in a hydrologic characteristic result in relatively little change in model-calculated values, the model is not sensitive to that characteristic.

As a partial determination of model sensitivity, 18 'simulations were made for a hypothetical, typical, undisturbed land segment and stream reach. The typical values of nine hydrologic characteristics are listed in table 9 . In the first of the 18 simulations, the typical value of average length of overland-flow path (LSUR) was increased by 50 percent, and other hydrologiccharacteristic values were held constant at the typical values. In the second simulation, average length of overland-path flow (LSUR) was decreased by 33 percent and other hydrologic-characteristic values were held constant at the typical values. In subsequent simulations, the remaining hydrologic characteristics were increased and decreased by the percentages indicated in table 9 while the other hydrologic-characteristic values were held constant at typical values. Results of the 18 simulations are listed in table 9. Calculated streamflow was most sensitive to changes in water-storage capacity of the lower soil zone (LZSN), deep-aquifer recharge (DEEPFR), and the groundwater recession constant (AGWRC). Calculated concentration of dissolved solids in streamflow was most sensitive to the concentration of dissolved solids in the ground-water contribution (TDSG). 


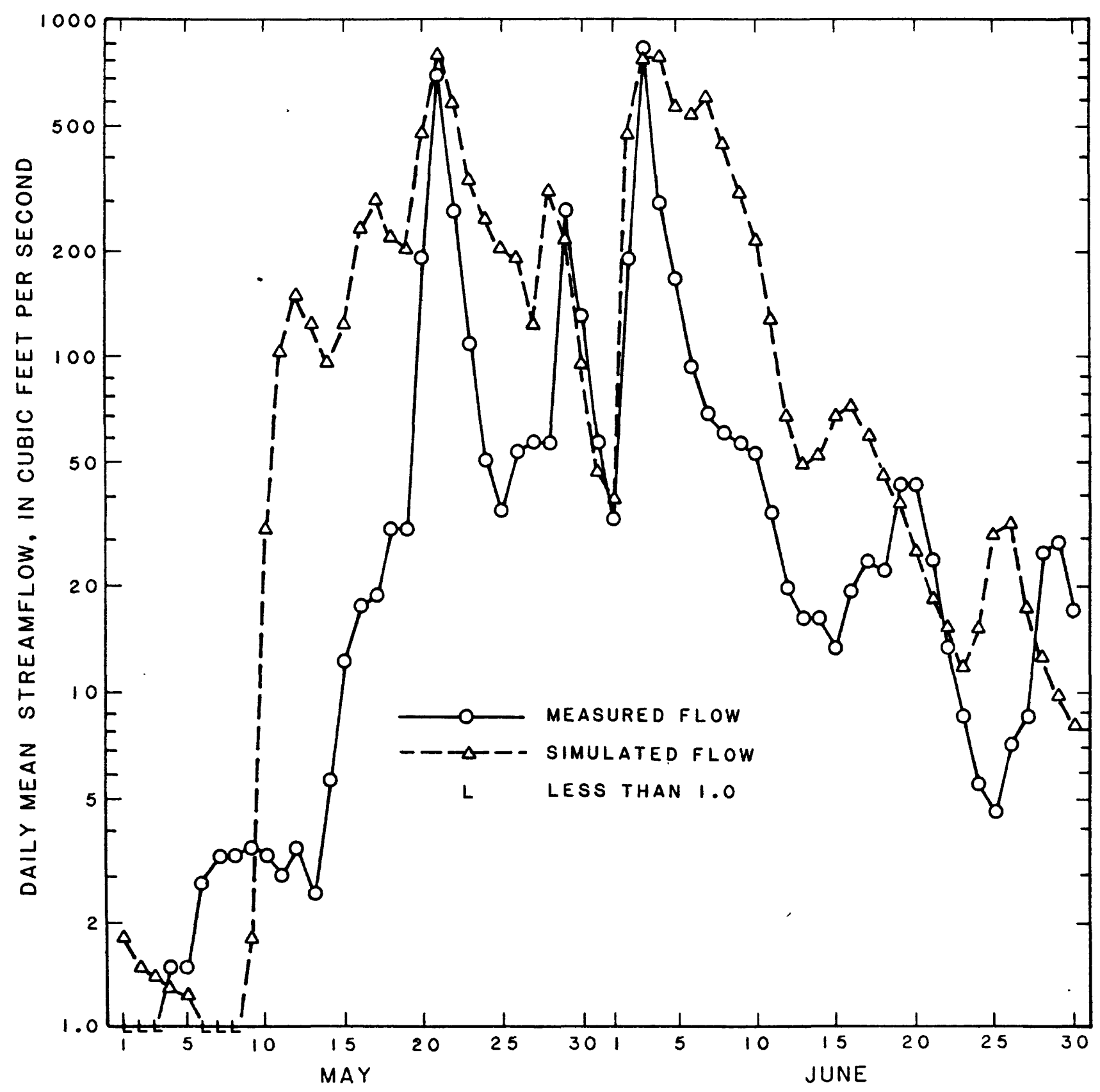

Figure 11.--Measured and simulated streamflow at station 06426500 Belle Fourche River below Moorcroft, Wyoming, during verification period May-June 1982. 
Table 9.--Effects of changes in values for hydrologic characteristics on minimum, mean, and maximum streamflow and dissolved-solids concentrations during a 2-month simulation period on a hypothetical land segment and stream reach

[LSUR, average length of overland-flow path, in feet; SLSUR, average slope of overland-flow path, in feet per foot; INFILT, infiltration capacity, in inches per hour; UZSN, water-storage capacity of the upper soil zone, in inches; LZSN, water-storage capacity of the lower soil zone, in inches; DEEPFR, deep aquifer recharge--the fraction of recharge from the lower soil zone that percolates to a deep aquifer; AGWRC, ground-water recession constant, dimensionless; TDSI and TDSG, dissolved-solids concentration in interflow and ground-water contributions, in milligrams per liter; $\mathrm{SO}_{4} \mathrm{I}$ and $\mathrm{SO}_{4} \mathrm{G}$, sulfate concentration in interflow and in ground-water contribution, in milligrams per liter; <, less than]

\begin{tabular}{|c|c|c|c|c|c|c|c|c|}
\hline \multirow{3}{*}{$\begin{array}{l}\text { Hydro- } \\
\text { logic } \\
\text { charac- } \\
\text { teristic }\end{array}$} & \multirow{3}{*}{$\begin{array}{c}\text { Typical } \\
\text { value }\end{array}$} & \multirow{3}{*}{$\begin{array}{l}\text { Change } \\
\text { in value } \\
\text { (percent) }\end{array}$} & \multicolumn{6}{|c|}{$\begin{array}{l}\text { Effect on calculated streamflow and dissolved- } \\
\text { solids concentration (percent) } \\
\end{array}$} \\
\hline & & & \multicolumn{3}{|c|}{ Streamflow } & \multicolumn{3}{|c|}{$\begin{array}{c}\text { Dissolved-solids } \\
\text { concentration }\end{array}$} \\
\hline & & & Minimum & Mean & Maximum & Minimum & Mean & Maximum \\
\hline \multirow[t]{2}{*}{ LSUR } & 600 & +50 & $<1$ & 0 & 0 & 0 & 0 & 0 \\
\hline & & -33 & $<1$ & 0 & 0 & 0 & 0 & 0 \\
\hline \multirow[t]{2}{*}{ SLSUR } & .06 & +50 & $<1$ & 0 & 0 & 0 & 0 & 0 \\
\hline & & -33 & $<1$ & 0 & 0 & 0 & 0 & 0 \\
\hline \multirow[t]{2}{*}{ INF ILT } & .15 & +50 & $<1$ & +7 & +9 & -6 & 0 & 0 \\
\hline & & -33 & $<1$ & -10 & -13 & 0 & 0 & 0 \\
\hline \multirow[t]{2}{*}{ UZSN } & .3 & +50 & $<1$ & 0 & 0 & 0 & 0 & 0 \\
\hline & & -33 & $<1$ & 0 & 0 & 0 & 0 & 0 \\
\hline \multirow[t]{2}{*}{ LZSN } & 4.0 & +50 & $<1$ & -45 & -37 & -34 & -1 & 0 \\
\hline & & -33 & $<1$ & +51 & +19 & 0 & 0 & 0 \\
\hline \multirow[t]{2}{*}{ DEEPFR } & .70 & $1+14$ & $<1$ & -37 & -37 & 0 & -1 & 0 \\
\hline & & -14 & $<1$ & +39 & +35 & 0 & 0 & 0 \\
\hline \multirow[t]{2}{*}{ AGWRC } & .70 & $1+21$ & $<1$ & -13 & -37 & +6 & +2 & -1 \\
\hline & & -21 & $<1$ & +8 & +29 & +5 & 0 & 0 \\
\hline \multirow[t]{2}{*}{ TDSI } & 160 & +50 & $<1$ & 0 & 0 & 0 & 0 & 0 \\
\hline & & -33 & $<1$ & 0 & 0 & 0 & 0 & 0 \\
\hline \multirow[t]{2}{*}{ TDSG } & 1,600 & +50 & $<1$ & 0 & 0 & +50 & +50 & +50 \\
\hline & & -33 & $<1$ & 0 & 0 & -33 & -33 & -33 \\
\hline
\end{tabular}

${ }^{1}$ These values could not be changed by the same percentage as the other characteristics because their upper limit is 1.0 .

\section{Effects of Mining}

After calibration and verification, the model was used to calculate changes in streamflow and changes in dissolved-solids and sulfate concentrations that result from mining. Three conditions were considered: Premining, during-mining, and postmining. The calibrated model was assumed to adequately represent the hydrologic system in the premining condition using the values for hydrologic characteristics listed in table 7 . Although the mines have 
varying areas of disturbed land at any one time during mining, the duringmining condition assumed the maximum disturbed area for all mines at the same time. The maximum disturbed area was assumed to equal the area mined during a 5-year period at each mine, a total of $9.6 \mathrm{mi}^{2}$, because reclamation commonly is completed within 5 years after mining ceases. The remainder of the permit areas, $49.8 \mathrm{mi}^{2}$, was assumed to have been mined and reclaimed. The postmining condition assumed the combined permit areas $\left(59.4 \mathrm{mi}^{2}\right.$ ) were reclaimed, and the sediment and flood-storage ponds remained in place as they would for 10 years after completion of reclamation.

For these applications of the model, measured and estimated rainfall and evaporation data for May and June 1980 and May and June 1982 were used. As the data in table 6 indicate, the precipitation for May and June 1980 was slightly less than the long-term average for May and June, and the precipitation for May and June 1982 was more than average. Thus, the periods used represent a range, but not the extremes, of climatic conditions for a spring season. The rainfall was assumed to be uniformly distributed over the land segments. For clarification, the period with less than average rainfall, May and June 1980, is identified as the period of "rainfall A", and the period with greater than average rainfall, May and June 1982, is identified as the period of "rainfall B." Also, changes in simulated flow and changes in concentrations of dissolved solids and sulfate are given in percentages rather than in physical units. The periods remain identified as May and June to make clear that the simulations do not represent winter (snowmelt) or midsummer (isolated thunderstorm) conditions.

Sediment and flood-storage ponds were assumed to be large enough to store the runoff from a 24-hour rainfall having an average recurrence interval of 10 years (a 2.8-in. rainfall with a maximum hourly rate of 1.18 in., from which the model calculated runoff of $0.76 \mathrm{in.}$ from a typical mine area during mining). The ponds were assumed to be empty at the beginning of each simulation.

The assumed concentrations for chemical-quality constituents were for worst-case conditions. For during-mining and postmining applications, the largest dissolved-solids and sulfate concentrations for coal and spoil were used. Premining concentrations vary considerably. The changes indicated by the simulations are extremely unlikely but indicate an upper limit.

Values of the hydrologic characteristics that were changed to represent the disturbed and reclaimed areas are listed in the following table (see table 7 for definitions and premining values):

\begin{tabular}{lcc}
\hline \multicolumn{1}{c}{$\begin{array}{c}\text { Hydrologic } \\
\text { characteristic }\end{array}$} & $\begin{array}{c}\text { Disturbed, } \\
\text { unreclaimed }\end{array}$ & $\begin{array}{c}\text { Disturbed, } \\
\text { reclaimed }\end{array}$ \\
\hline LSUR (feet) & 400 & 2,000 \\
SLSUR (foot per foot) & .04 & .03 \\
INFILT (inches per hour) & not changed & 12.0 \\
TDSG (milligrams per liter) & 6,500 & 6,500 \\
SO4G (milligrams per liter) & 3,000 & 3,000 \\
Sediment/flood storage & Yes & Yes \\
\hline
\end{tabular}

${ }^{1}$ Based on information in Gifford (1981) 
Simulated streamflows resulting from rainfall $\mathrm{A}$ were small and changes in flow from premining to during-mining and postmining conditions were less than 2.5 percent. Flows simulated using rainfall B were larger than flows simulated using rainfall A. A hydrograph showing simulated streamflow resulting from rainfall $B$ at the downstream site for premining, during-mining, and postmining conditions is in figure 12. Changes in selected streamflow characteristics at four sites downstream from mining are summarized in table 10 .

Simulated dissolved-solids and sulfate concentrations from rainfall A had some decreases from premining conditions to postmining worst-case conditions. Worst-case changes in dissolved-solids concentrations for rainfall A are summarized in table 11; percentage changes in sulfate concentrations were nearly identical to those for dissolved-solids concentrations.

The 2 months of rainfall $B$ resulted in simulated runoff from the mine areas about equal to the storage capacity of the ponds. For some areas, the model calculated minute quantities of outflow from the ponds in the last few days of the simulation period. Dissolved-solids and sulfate concentrations had been increased by evaporation from the ponds and were further increased by evaporation from the stream channels. In reality, mine operators would pump water from the ponds to use for dust control and thereby prevent the occurrence of outflow resulting from moderate inflows accumulating during a period of several weeks. Therefore, in this summary the large concentrations of dissolved solids and sulfate were ignored for streamflows less than $1.0 \mathrm{ft}^{3} / \mathrm{s}$.

Simulated dissolved-solids and sulfate concentrations for flows exceeding $1.0 \mathrm{ft}^{3} / \mathrm{s}$ were decreased as much as 49 percent from premining to during-mining conditions by rainfall B. Changes in dissolved-solids concentrations for rainfall B are summarized in table 12; percentage changes in sulfate concentrations were nearly the same as those for dissolved-solids concentrations.

Although sediment was not included in the model, the decreases in simulated streamflows would indicate decreases in suspended-sediment concentration. The flat slopes and small quantities of surface runoff from reclaimed areas should produce a cumulative result of equal to or less than premining suspended-sediment concentrations downstream if: (1) The sedimentation ponds continue to perform as designed for as long as they are in existence, and (2) the vegetation established on the reclaimed land controls erosion as well or better than the original vegetation.

Because the 2-month verification period indicated the possibility of bias in the hydrologic characteristics used in the model, limited additional study was done to investigate the effects of biased values for hydrologic characteristics on evaluation of the effects of mining. Bias in a hydrologic model sometimes has only a small effect on the validity of conclusions concerning differences or changes in certain calculated values. For example, imagine that a reservoir was surveyed during a period when outflow was żero. Sediment deposition since the time the reservoir was surveyed may have decreased the capacity so that the stage-capacity curve is now biased, but all the deposition may have been at lower stages than those involved in the current use of the curve. In that case the bias is equal at the two stages used in calculating the inflow, and the calculated inflow is accurate. Although use of the HSPF model to evaluate effects of mining is not claimed to be exactly parallel to the example just presented, a similar principle may be applicable. 


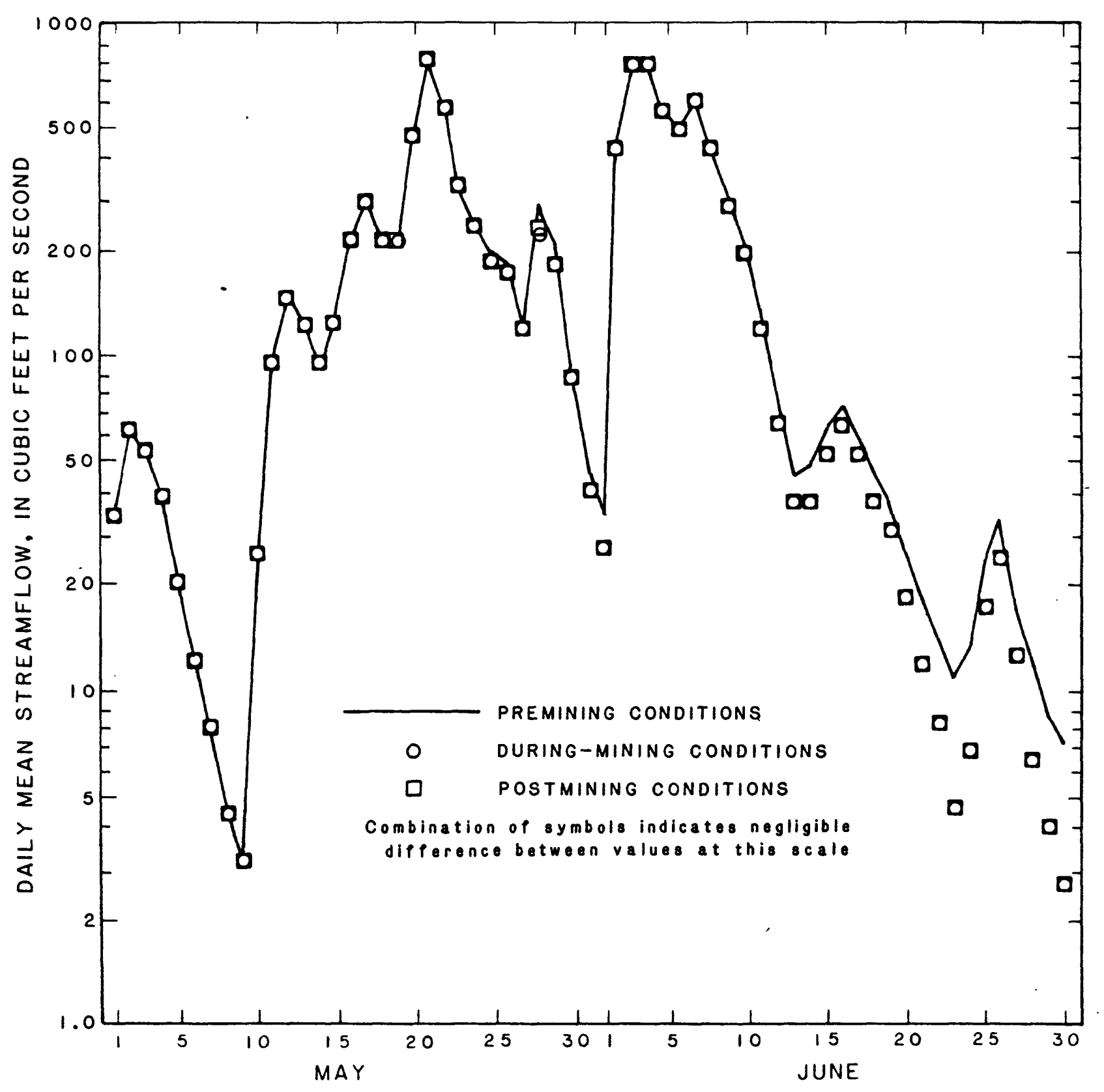

Figure 12.--Simulated streamflow of Belle Fourche River at inlet of Keyhole Reservoir, using rainfall B for premining, during-mining, and postmining conditions. 
Table 10.--Changes in simulated streamflow from premining to during-mining and postmining conditions using rainfall $B$

\begin{tabular}{|c|c|c|c|c|}
\hline \multirow[b]{2}{*}{ Station or site } & \multirow[b]{2}{*}{ Condition } & \multicolumn{3}{|c|}{$\begin{array}{c}\text { Change from premining value } \\
\text { (percent) }\end{array}$} \\
\hline & & $\begin{array}{l}\text { Minimum } \\
\text { stream- } \\
\text { flow }\end{array}$ & $\begin{array}{l}\text { Median } \\
\text { stream- } \\
\text { flow }\end{array}$ & $\begin{array}{l}\text { Maximum } \\
\text { stream- } \\
\text { flow }\end{array}$ \\
\hline $\begin{array}{l}06425780 \\
\text { Belle Fourche River above }\end{array}$ & During mining & 0 & -9 & -31 \\
\hline Dry Creek, near Piney. & Postmining & 0 & -9 & -22 \\
\hline $\begin{array}{l}06425900 \\
\text { Caballo Creek at mouth, } \\
\text { near Piney. }\end{array}$ & $\begin{array}{l}\text { During mining } \\
\text { Postmining }\end{array}$ & 0 & $\begin{array}{l}-22 \\
-22\end{array}$ & $\begin{array}{l}-30 \\
-30\end{array}$ \\
\hline $\begin{array}{l}06426400 \\
\text { Donkey Creek near } \\
\text { Moorcroft. }\end{array}$ & During mining & 0 & -7 & -1 \\
\hline $\begin{array}{l}\text { Belle Fourche River } \\
\text { at inlet of } \\
\text { Keyhole Reservoir. }\end{array}$ & During mining & 0 & -4 & -2 \\
\hline
\end{tabular}

Table 11.--Changes in simulated dissolved-solids concentrations from premining to during-mining and postmining conditions using worst-case conditions with rainfall $A$

\begin{tabular}{|c|c|c|c|c|}
\hline \multirow[b]{2}{*}{ Station or site } & \multirow[b]{2}{*}{ Condition } & \multicolumn{3}{|c|}{$\begin{array}{c}\text { Change from premining value } \\
\text { (percent) }\end{array}$} \\
\hline & & $\begin{array}{l}\text { Minimum } \\
\text { dissolved- } \\
\text { solids } \\
\text { concen- } \\
\text { tration }\end{array}$ & $\begin{array}{c}\text { Median } \\
\text { dissolved- } \\
\text { solids } \\
\text { concen- } \\
\text { tration }\end{array}$ & $\begin{array}{l}\text { Maximum } \\
\text { dissolved } \\
\text { solids } \\
\text { concen- } \\
\text { tration }\end{array}$ \\
\hline $\begin{array}{l}06425780 \\
\text { Belle Fourche River above }\end{array}$ & During mining & 0 & 0 & 0 \\
\hline Dry Creek, near Piney. & Postmining & 0 & 0 & 0 \\
\hline $\begin{array}{l}06425900 \\
\text { Caballo Creek at mouth, } \\
\text { near Piney. }\end{array}$ & $\begin{array}{l}\text { During mining } \\
\text { Postmining }\end{array}$ & $\begin{array}{l}-7 \\
-7\end{array}$ & -4 & 0 \\
\hline $\begin{array}{l}06426400 \\
\text { Donkey Creek near } \\
\text { Moorcroft. }\end{array}$ & During mining & $\begin{array}{l}+1 \\
+1\end{array}$ & -7 & 0 \\
\hline $\begin{array}{l}\text { Belle Fourche River } \\
\text { at inlet of } \\
\text { Keyhole Reservoir. }\end{array}$ & During mining & 0 & -1 & 0 \\
\hline
\end{tabular}


Table 12.--Changes in simulated dissolved-solids concentrations from premining to during-mining and postmining conditions using worst-case conditions with rainfall $B$

\begin{tabular}{|c|c|c|c|c|}
\hline \multirow[b]{2}{*}{ Station or site } & \multirow[b]{2}{*}{ Condition } & \multicolumn{3}{|c|}{$\begin{array}{c}\text { Change from premining value } \\
\text { (percent) }\end{array}$} \\
\hline & & $\begin{array}{l}\text { Minimum } \\
\text { dissolved- } \\
\text { solids } \\
\text { concen- } \\
\text { tration }\end{array}$ & $\begin{array}{l}\text { Median } \\
\text { dissolved- } \\
\text { solids } \\
\text { concen- } \\
\text { tration }\end{array}$ & $\begin{array}{l}\text { Maximum } \\
\text { dissolved- } \\
\text { solids } \\
\text { concen- } \\
\text { tration }{ }^{1}\end{array}$ \\
\hline $\begin{array}{l}06425780 \\
\text { Belle Fourche River above }\end{array}$ & During mining & -13 & -5 & -36 \\
\hline Dry Creek, near Piney. & Postmining & -21 & -5 & -36 \\
\hline $\begin{array}{l}06425900 \\
\text { Caballo Creek at mouth, } \\
\text { near Piney. }\end{array}$ & $\begin{array}{l}\text { During mining } \\
\text { Postmining }\end{array}$ & $\begin{array}{l}-42 \\
-42\end{array}$ & $\begin{array}{l}-13 \\
-13\end{array}$ & $\begin{array}{l}-49 \\
-49\end{array}$ \\
\hline $\begin{array}{l}06426400 \\
\text { Donkey Creek near } \\
\text { Moorcroft. }\end{array}$ & During mining & -12 & -4 & 0 \\
\hline $\begin{array}{l}\text { Belle Fourche River } \\
\text { at inlet of }\end{array}$ & During mining & -2 & -3 & -4 \\
\hline Keyhole Reservoir. & Postmining & -8 & -3 & -3 \\
\hline
\end{tabular}

${ }^{1}$ For streamflows less than 1.0 cubic foot per second.

Three pairs of simulations were run to investigate effects of bias in the hydrologic characteristics. The first pair of simulations indicated the change in streamflow or dissolved-solids concentration if the correct values of infiltration capacity for the unmined areas (unmined INFILT) were five times as large as the values arrived at by calibration (table 13). The second pair indicated the changes when a value of $1.0 \mathrm{in}$. rather than 0.3 in. was used for the water-storage capacity of the upper soil zone (UZSN) for all areas (all other hydrologic-characteristic values unchanged from their calibrated values) (table 13). The third pair of simulations indicated the change in streamflow or dissolved-solids concentration if the value of infiltration capacity for reclaimed areas (reclaimed INFILT) was changed from 2.0 to 0.3 in. (table 13). This study did not investigate the effects of concurrent changes in two or more parameters. 
The results in table 13 are expressed as percentage changes from premining to postmining conditions. The "unchanged" percentages are from tables 10 and 12. The results were obtained using the calibrated values for hydrologic characteristics for the unmined areas and INFILT $=2.0 \mathrm{in} . / \mathrm{hr}$ for reclaimed areas. The results in table 13 indicate, for example, at station 06425780 if the correct value of INFILT for unmined areas was 5 times the calibrated value but the calibrated values were correct for the other values of hydrologic characteristics, the change in median streamflow from premining to postmining conditions would be -14 percent instead of the -9 percent shown in table 10 . Changes in sulfate concentrations are not shown, but are nearly the same percentage as changes in dissolved-solids concentrations.

The results shown in table 13 indicate little effect of biased values for hydrologic characteristics on the evaluation of cumulative effects of mining on surface water. Probably because of the sediment and flood-storage ponds more than any other factor, simulations using varied parameter values consistently indicated decreases in flow, dissolved solids, and sulfate between premining to during-mining and postmining conditions. Because of the large disturbed area, decreases were small at the site farthest downstream (the inlet to Keyhole Reservoir).

Table 13.--Sensitivity of predicted changes in streamflow and dissolved solids to bias in INFILT or UZSN for postmining conditions and rainfall $B$

(INFILT, infiltration capacity, in inches per hour; UZSN, water-storage capacity of the upper soil zone, in inches; $\mathrm{ft}^{3} / \mathrm{s}$, cubic foot per second

\begin{tabular}{|c|c|c|c|c|c|c|c|}
\hline \multirow{2}{*}{ Station or site } & \multirow{2}{*}{ Description } & \multicolumn{6}{|c|}{$\begin{array}{cc}\text { Change from premining to postmaning value (percent) } \\
\text { Streamflow } & \text { Dissolved-solids concentration } \\
\end{array}$} \\
\hline & & $\begin{array}{c}\text { Mini- } \\
\text { mum }\end{array}$ & Median & $\begin{array}{c}\text { Maxi- } \\
\text { mum }\end{array}$ & $\begin{array}{c}\text { Mini- } \\
\text { mum }\end{array}$ & Median & $\begin{array}{l}\text { Maximum for } \mathrm{flows} \\
\text { exceeding } 1.0 \mathrm{ft}^{3} / \mathrm{s}\end{array}$ \\
\hline $\begin{array}{l}0625780 \\
\text { Belle Fourche } \\
\text { River above } \\
\text { Dry Creek near } \\
\text { Piney. }\end{array}$ & $\begin{array}{l}\text { Percentages listed in tables } 10 \\
\text { and } 12 \text {. } \\
\text { Unmined INFILT changed } \\
\text { UZSN changed }{ }^{2} \\
\text { Reclaimed INFILT changed }{ }^{3}\end{array}$ & $\begin{array}{l}0 \\
0 \\
0\end{array}$ & $\begin{array}{r}-9 \\
-14 \\
-8 \\
-9\end{array}$ & $\begin{array}{r}-1 \\
-1 \\
-22\end{array}$ & $\begin{array}{r}-4 \\
-21 \\
-21\end{array}$ & $\begin{array}{l}-6 \\
-5 \\
-5\end{array}$ & $\begin{array}{l}-37 \\
-36 \\
-36\end{array}$ \\
\hline $\begin{array}{l}06425900 \\
\text { Caballo Creek } \\
\text { at mouth near } \\
\text { Piney. }\end{array}$ & $\begin{array}{l}\text { Percentages listed in tables } 10 \\
\text { and } 12 \text {. } \\
\text { Unmined INFILT changed } \\
\text { UZSN changed } \\
\text { Reclaimed INFILT changed }{ }^{3}\end{array}$ & $\begin{array}{l}0 \\
0 \\
0\end{array}$ & $\begin{array}{l}-32 \\
-21 \\
-21\end{array}$ & $\begin{array}{r}-2 \\
-30 \\
-30\end{array}$ & $\begin{array}{l}-42 \\
-45 \\
-42 \\
-42\end{array}$ & $\begin{array}{l}-13 \\
-18 \\
-13 \\
-13\end{array}$ & $\begin{array}{l}-49 \\
-49 \\
-48 \\
-49\end{array}$ \\
\hline $\begin{array}{l}\text { Belle Fourche } \\
\text { River at inlet } \\
\text { to Keyhole } \\
\text { Reservoir. }\end{array}$ & $\begin{array}{l}\text { Percentages listed in tables } 10 \\
\text { and } 12 \text {. } \\
\text { Unmined INFILT changed }{ }^{l} \\
\text { UZSN changed }{ }^{2} \\
\text { Reclaimed INFILT changed }{ }^{3}\end{array}$ & $\begin{array}{l}0 \\
0 \\
0 \\
0\end{array}$ & $\begin{array}{l}-4 \\
-14 \\
-11 \\
-4\end{array}$ & $\begin{array}{l}-2 \\
-1 \\
-1 \\
-2\end{array}$ & $\begin{array}{r}0 \\
0 \\
-9\end{array}$ & $\begin{array}{l}=3 \\
-4 \\
-3 \\
-3\end{array}$ & $\begin{array}{l}-5 \\
-2 \\
-6\end{array}$ \\
\hline
\end{tabular}
hour.

'Range of INFILT for unmined areas changed from 0.1 to 0.3 inches per hour to 0.5 to 1.5 inches per

2UZSN for all areas changed from 0.3 to 1.0 inches.

${ }^{3}$ INFILT for reclaimed areas changed from 2.0 to 0.3 inches per hour. 
Transferability to Little Powder River basin

To increase the usefulness of the surface-water model for assessing coalmining effects in the Powder River structural basin, a comparative analysis of the Belle Fourche and Little Powder River basins was made to determine if the results for the Belle Fourche model have transfer value to studies of the Little Powder River basin. Although many of the hydrologic characteristics are similar in the two basins, the differences may preclude accurate prediction in the Little Powder River using the Belle Fourche River basin model. A summary of the comparisons between the two basins follows.

The Belle Fourche River basin and the Little Powder River basin have similar climates. Both have comparable weather patterns and have no land features that produce any significant orographic effects. The National Weather Service collects climatological data at several sites in both areas; however, long-term data (30-year averages) are only available for the Belle Fourche River basin.

There are minor differences in average annual precipitation in the two areas. Average annual precipitation in the Little Powder River basin ranges from 14 to 16 in/yr, whereas in the Belle Fourche River basin, it ranges from 12 to $14 \mathrm{in} / \mathrm{yr}$ (fig. 4). Precipitation averages during 1975-82 for two centrally located climatological stations in each basin--Weston $1 \mathrm{E}$, in the Little Powder River basin, and Dillinger, in the Belle Fourche River basin are listed in table 2. Weston $1 \mathrm{E}$ does not have 30-year averages as does Dillinger. The shorter period (1975-82) also corresponds with the length of records at many streamflow-gaging stations in both basins.

Average temperature, temperature extremes, and seasonal variability of temperature are similar in both basins. Monthly averages for the long-term stations in the Belle Fourche River basin and comparisons of monthly average temperature between Weston $1 \mathrm{E}$, in the Little Powder River basin, and Dillinger, in the Belle Fourche River basin, for 1975-82, are listed in table 3 .

The principal geologic units in the two basins are the same. However, the Belle Fourche River flows across the outcrop areas of bedrock units in the basin, flowing mostly on the Wasatch Formation; the Little Powder River flows more nearly along the strike of beds with the main channel flowing mostly on the Fort Union Formation. Alluvium in both basins is derived locally and is predominantly fine grained; however, the maximum thickness of the alluvium of the Belle Fourche River is 33 feet and that of the Little Powder River is 60 feet (W.G. Hodson, written commun., 1975).

Soil characteristics are moderately different within the basins and between the basins (Young and Singleton, 1977). The erodibility of soils in each basin is classified as moderate with the exception of the eastern one-third of the Belle Fourche River basin, which is classified low to moderate. The soils generally are fine grained, contain little organic matter, and are alkaline. Clay content generally is less than 35 percent. Runoff potential for most of each basin is moderately high. Alluvial material with medium erodibility and moderately low to moderately high runoff potential is present along the main-stem streams. 
Vegetation in the two basins is classified by Young and Singleton (1977, p. 2) as being in two different vegetation zones of the Northern Plains (both based on annual precipitation). The Little Powder River basin is in the 15to 17-in. precipitation zone and most of the Belle Fourche River basin is in the 10- to 14-in. precipitation zone. The woodland and grassland species comprising the natural vegetation in each precipitation zone is listed in table 4 .

The variability in streamflow between the two basins is similar to the areal variability in average annual precipitation. Mean annual discharge at Little Powder River streamflow-gaging stations appears to be moderately larger than at Belle Fourche River stations; however, the difference in periods of record for stations in the two basins is likely to distort this comparison. Differences in mean annual flow between the basins also was determined by Lowham (1976, p. 4, 5, 32, 33) in a regional study done to provide a method for computing mean annual flow and peak flow (for selected frequencies) for natural streams in Wyoming. Lowham (1976) shows two different hydrologic regions for this part of Wyoming. Approximately the downstream two-thirds of the Belle Fourche basin and the upstream one-fifth of the Little Powder River basin are in the same hydrologic region with smaller estimated mean annual discharge than the remainder of each basin. The Belle Fourche River basin contains only one major reservoir and numerous smaller reservoirs; the Little Powder River basin contains only small irrigation-diversion reservoirs.

A comparison of flow-duration curves for the two basins indicates that unit discharges (discharge per square mile) at the Little Powder River streamflow-gaging stations are slightly greater than those for the Belle Fourche River stations with the exception of Donkey Creek near Moorcroft, which is nearly the same as the Little Powder River basin. However, the overall steep slopes of all flow-duration curves indicate that flow is mainly from direct runoff. (See figs. 5 and 6. )

Flood characteristics appear similar, with only moderate differences discernible. The flow-duration curves (figs. 5 and 6 ) show some convergence at the higher flow end of the curves; however the curves for the Belle Fourche River streamflow-gaging stations remain to the left of those for the Little Powder River stations. Lowham (1976, p. 5) shows the 'same hydrologic regions for flood-frequency relations as were previously discussed for mean annual discharge. The hydrologic region, comprising the downstream part of the Belle Fourche and the upstream part of the Little Powder River basins, is estimated to produce smaller discharges for identical drainage areas and frequency of occurrence.

A comparison of peak discharges versus drainage areas for flood peaks in the two basins is shown in figure 7. A reference lines was manually fitted to help visually determine if there was a trend for floodflows in one basin to be on one side of the line, which would indicate a difference in the floodproducing characteristics of the two basins. The scatter about the line indicates no major differences between flood-producing characteristics of the two basins based on peak discharge. 


\section{LANDSCAPE STABILITY}

Surface coal mining disturbs substantial areas of land surface, and, therefore, affects stream channels and drainage networks. The disturbance may affect natural channel stability some distance upstream or downstream from mining as well as locally. An undesirable modification of the drainage network, may result in an increase in sedimentation and erosion.

The design of stable drainage networks for surface-mined areas is critical to the type and. degree of use the land may support after reclamation. Undesirable rates of erosion and sedimentation can be detrimental to reclaimed areas, adjacent areas, and downstream water quality. Generally, the better postmining topography can be restored and fitted to surrounding natural conditions, the greater the likelihood of stable drainage networks and successful reclamation (Bishop, 1980).

The Wyoming Environmental Quality Act (Wyoming State Legislature, 1973) requires that surface coal-mining operations provide a plan to minimize disturbances to the prevailing hydrologic balance at the mine site and in adjacent areas, and to protect the quality and quantity of water in surface- and ground-water systems during and after mining. Guidelines prepared by the Wyoming Department of Environmental Quality (1980) recommend that various basin and channel characteristics be measured by the mining companies to aid in the reclamation of surface-drainage systems.

\section{Description of Drainage Networks}

The channel network of a drainage basin is the number and form of its tributaries and main streams. When surface geology is fairly uniform, the network of channels that develops is dendritic, as shown by the example basin in figure 13. Drainage networks of the study area generally are dendritic, although erosion-resistant outcrops, different lithologies, and geologic structures such as joints or faults may affect the orientation of the streams.

A quantitative description of drainage networks in the study area was made using a method commonly referred to as the Horton analysis (Horton, 1945). The fundamental aspect of the Horton analysis is the relation of certain physical characteristics, such as drainage area, stream number, and stream length, to stream order. Stream order is defined as the position of a stream within a drainage network (fig. 13). The smallest channels of the network are unbranched tributaries, which are designated as first-order streams. When two first-order streams join, the resulting channel is a second-order stream. Third-order streams receive one or more tributaries of the second order, but may also receive first-order streams, and so on. In this system, the main stream has the highest order. The order of the main stream describes the order of the basin.

Stream order generally is determined by examining the drainage network of a basin on topographic maps. The map scale limits the size of the smallest stream that may be recognized. To include the smallest rills evident in the basin in stream ordering, as many as four orders of streams would have to be added to the smallest streams shown on $1: 24,000-\mathrm{scale}$ maps (Leopold and Miller, 1956). However, the network shown by $1: 24,000-s c a l e$ maps is considered adequate to define the important aspects of landscape stability. 


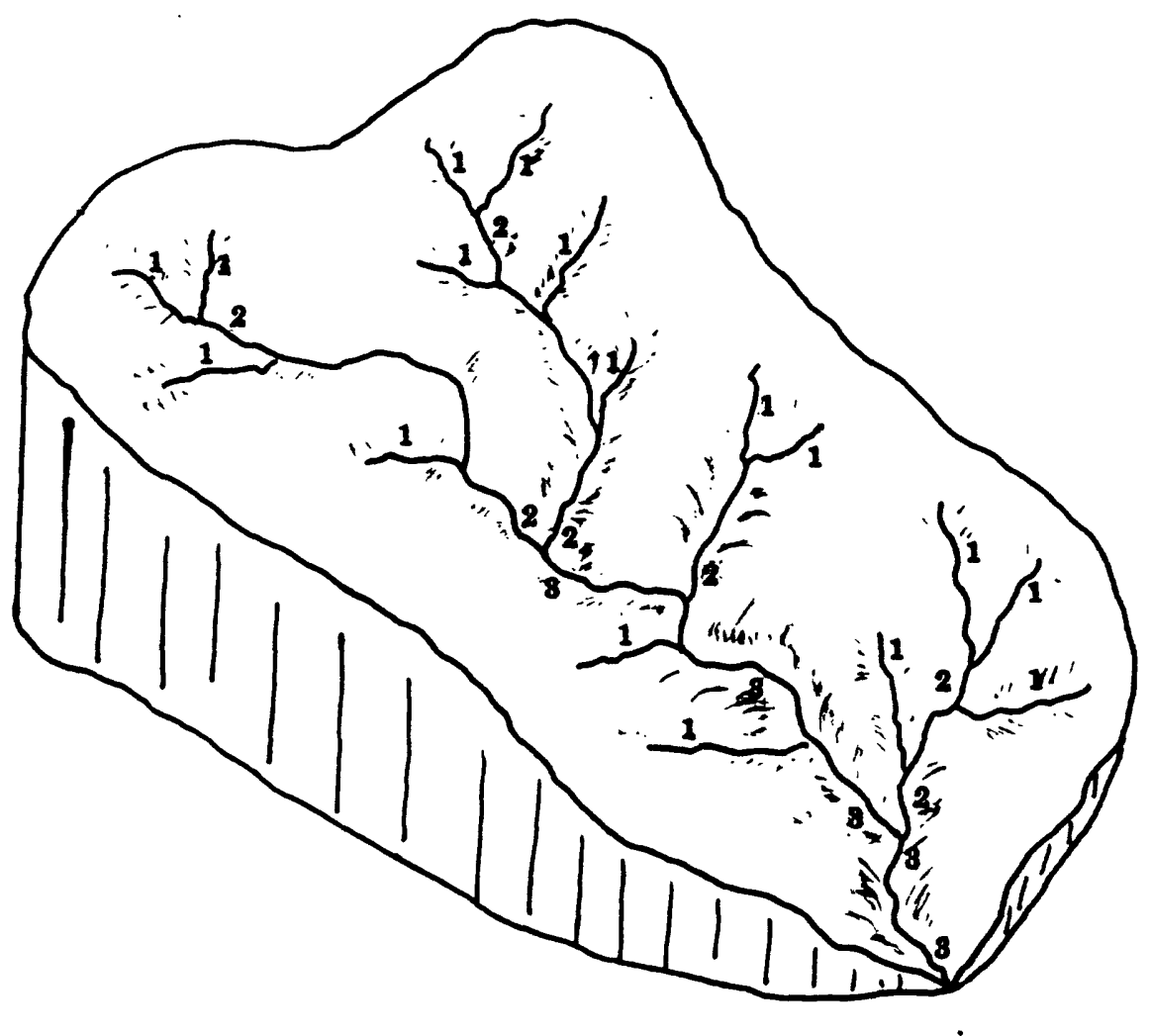

Figure 13.--Sketch of third-order basin showing first-, second-, and third-order streams. 
A sample of 102 drainage basins was selected for determining the physical characteristics of drainage networks in the study area. The selected basins are natural, with insignificant controls or effects occurring from manmade developments. All of the basins are located within $15 \mathrm{mi}$ of a coal-permit area.

The basins were selected using the following procedure. The coal-permit areas were plotted on 25 U.S. Geological Survey 1:24,000-scale topographic maps. An overlay grid, exactly the size of one map, was divided into 150 rectangles of equal area. A mathematical procedure was used to generate a random grid number, and 51 drainage basins (fig. 14) located in the randomly selected grids on the 25 maps were delineated for analysis. Due to the size of the grid, only second- or higher order basins were selected through this process. A subset of 51 first-order basins was then selected from the larger basins, using a random process to select 1 first-order basin from each of the larger basins.

\section{Use of the Data}

Twenty-two physical characteristics were measured for each of the secondor higher order basins using a computerized digitizer. A description of each of the characteristics is given in table 14, and the values measured for each of the 51 basins are given in table 15 .

Due to limitations of the map scale, some of the characteristics measured for the second- or higher order basins could not be accurately measured for the smaller first-order basins. The characteristics measured for the firstorder basins are identified in table 14; the values are listed in table 16.

A statistical summary of the values of the physical characteristics is given in tables 17-20 for each of the basin orders. The tables list the minimum and maximum values measured, the arithmetic mean, the geometric mean, and the standard deviation of the sample. The arithmetic and geometric mean values for each of the characteristics indicate the expected average magnitudes. The geometric mean, which is computed using logarithms of the values, generally is considered a better description of distributions in hydrology than the arithmetic mean, because the distributions usually are asymmetrical.

The physical characteristics of drainage networks commonly are interrelated. For example, as drainage area increases, the number of channels and the order of the main channel also increase. To determine those variables for which significant interrelations might exist, a correlation analysis was made. Results of this analysis are given in table 21.

Using these correlations as a guide, graphs (figs. 15-21) and regression relations (table 22) were developed for the physical characteristics that are significantly related and that are considered important to landscape stability. These relations can be used as aids in designing the reconstruction of drainage networks. 


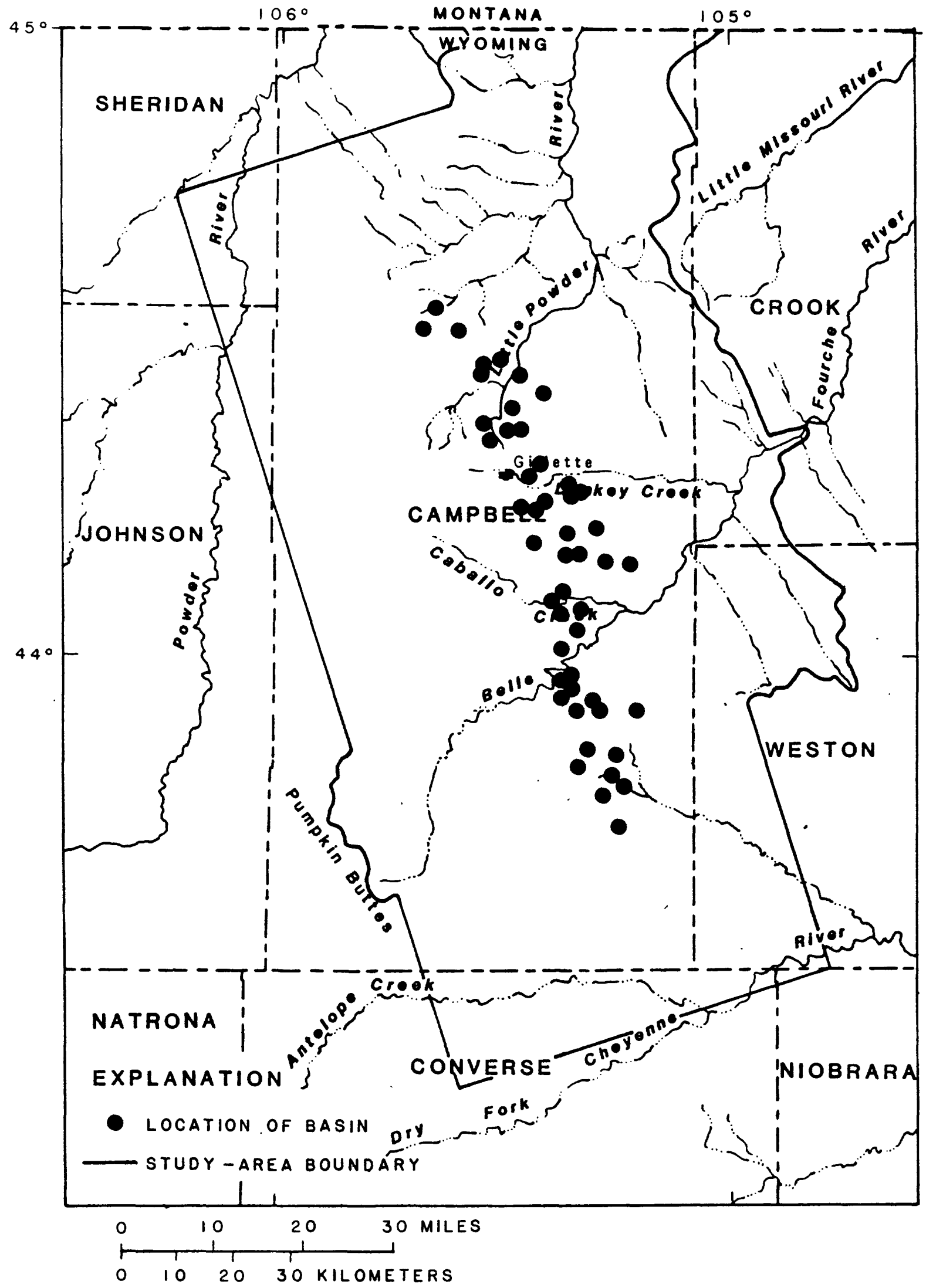

Figure 14.--Location of basins used to determine physical characteristics. 
Table 14.--Characteristics measured in landscape-stability analysis

[* indicates characteristics measured for first-order basins]

Characteristic
*Drainage area
Number of first-
order channels
Number of
second-order
channels
Number of
third-order
channels
Number of
fourth-order
channels
Length of first-
order channels
Length of second-
order channels
Length of third-
order channels
Length of fourth-
order channels
*Basin length
ord

Total number of channels in the drainage basin that are classified as third order.

Total number of channels in the drainage basin that are classified as fourth order.

Summation of lengths of all channels classified as first order, in miles.

Summation of lengths of all channels classified as second order, in miles.

Summation of lengths of all channels classified as third order, in miles.

Summation of lengths of all channels classified as fourth order, in miles.

Straight line distance across the drainage basin from drainage divide above the dominant channel to the basin mouth, in miles.

* Basin perimeter Perimeter of drainage basin, in miles.

Basin width Representative width of the drainage basin, in miles.

*Valley length Length of the valley along the dominant channel, in miles.

$*$ Channel length Length of the dominant channel measured on the blue streamline as shown on a $1: 24,000$-scale map, in miles.

*Basin relief Difference in altitude between the drainage divide at the head of the dominant channel and the basin mouth, in feet. 
Table 14.--Characteristics measured in landscape-stability analysis--Continued

\begin{tabular}{|c|c|}
\hline Characteristic & Explanation of characteristic \\
\hline Used relief & $\begin{array}{l}\text { Difference in altitude between two points on the channel, } \\
\text { in feet. For the first-order basins, the points were } \\
\text { selected at each end of the blue streamline. For the } \\
\text { second- and higher order basins, the points were selected } \\
\text { a.t } 15 \text { and } 85 \text { percent of the channel length. }\end{array}$ \\
\hline Channel slope & $\begin{array}{l}\text { Used relief divided by the length of channel between the } \\
\text { points identified in used relief, in feet per foot. This } \\
\text { depicts an average channel slope, which should not be } \\
\text { confused or compared with values that are measured at } \\
\text { particular locations along channels. }\end{array}$ \\
\hline Basin order & Order of the channel at the drainage basin mouth. \\
\hline$*$ Sinuosity ratio & $\begin{array}{l}\text { Channel length divided by valley length. This depicts an } \\
\text { average sinuosity for the stream, which should not be } \\
\text { confused with values that are measured at particular } \\
\text { locations along channels. }\end{array}$ \\
\hline$*$ Relief ratio & Drainage basin relief divided by basin length. \\
\hline $\begin{array}{l}\text { *Total channel } \\
\text { length. }\end{array}$ & $\begin{array}{l}\text { Summation of lengths of all channels of all orders in the } \\
\text { drainage basin, in miles. }\end{array}$ \\
\hline$*$ Drainage density & $\begin{array}{l}\text { Total channel length divided by the drainage area, in miles } \\
\text { per square mile. }\end{array}$ \\
\hline $\begin{array}{l}* \text { Circularity } \\
\quad \text { ratio }\end{array}$ & $\begin{array}{l}\text { Area of the drainage basin divided by the area of a circle } \\
\text { having the same perimeter as the drainage basin. }\end{array}$ \\
\hline Stream frequency & $\begin{array}{l}\text { Total number of channels of all orders divided by the } \\
\text { drainage area, in streams per square mile. }\end{array}$ \\
\hline $\begin{array}{l}\text { Maximum side- } \\
\text { slope relief }\end{array}$ & $\begin{array}{l}\text { Difference in altitude between the hilltop and the channel } \\
\text { on the valley side slope at the point of maximum differ- } \\
\text { ence, in feet. }\end{array}$ \\
\hline $\begin{array}{l}\text { Sideslope } \\
\text { distance }\end{array}$ & $\begin{array}{l}\text { Straight-line distance measured in a horizontal plain } \\
\text { between the hilltop and the channel at the same point as } \\
\text { the maximum sideslope relief was measured, in miles. }\end{array}$ \\
\hline $\begin{array}{l}\text { *Maximum value } \\
\text { sideslope }\end{array}$ & $\begin{array}{l}\text { Maximum value of sideslope relief divided by the sideslope } \\
\text { distance, in feet per foot. }\end{array}$ \\
\hline
\end{tabular}




\begin{tabular}{|c|c|c|c|c|c|c|c|c|c|c|c|c|c|c|c|c|c|}
\hline \multirow{3}{*}{\multicolumn{3}{|c|}{$\underset{\text { name }}{\operatorname{Map}}$}} & \multirow{3}{*}{$\begin{array}{l}\text { Basin } \\
\text { sequence } \\
\text { number }\end{array}$} & \multirow{3}{*}{$\begin{array}{c}\text { Drainage } \\
\text { area } \\
\text { (square } \\
\text { miles) }\end{array}$} & \multicolumn{9}{|c|}{ For indicated order number of channel } & \multirow{3}{*}{$\begin{array}{l}\text { Basin } \\
\text { length } \\
\text { (miles) }\end{array}$} & \multirow{3}{*}{$\begin{array}{c}\text { Basin } \\
\text { perim- } \\
\text { eter } \\
\text { (miles) }\end{array}$} & \multirow{3}{*}{$\begin{array}{c}\text { Basin } \\
\text { width } \\
\text { (miles) }\end{array}$} & \multirow{3}{*}{$\begin{array}{l}\text { Valley } \\
\text { length } \\
\text { (miles) }\end{array}$} \\
\hline & & & & & \multicolumn{5}{|c|}{ Number of channels } & \multicolumn{4}{|c|}{$\begin{array}{c}\text { Total length of channels, } \\
\text { in miles }\end{array}$} & & & & \\
\hline & & & & & 1st & & & & $4 \mathrm{th}$ & lst & $2 d$ & $3 d$ & $4 \mathrm{th}$ & & & & \\
\hline Calf & Creek & & D59 & 0.74 & 5 & 2 & & 1 & 0 & 1.42 & 1.28 & 0.62 & 0.00 & 1.66 & 4.28 & 0.47 & 1.50 \\
\hline Calf & Creek & & D58 & 7.73 & 34 & 11 & & 2 & 1 & 12.01 & 7.60 & 3.31 & 4.14 & 5.29 & 13.03 & 1.97 & 4.97 \\
\hline $\mathrm{Ca} \perp \mathrm{f}$ & Creek & & D57 & .91 & 3 & 1 & & 0 & 0 & 2.51 & .48 & .00 & .00 & 1.42 & 3.88 & .84 & 1.25 \\
\hline Calf & Creek & & D56 & .71 & 5 & 1 & & 0 & 0 & 1.06 & 1.64 & .00 & .00 & 1.67 & 4.05 & .52 & 1.50 \\
\hline Fort & in Draw & & D55 & .51 & 3 & 1 & & 0 & 0 & 1.55 & .95 & .00 & .00 & 1.57 & 3.64 & .42 & 1.38 \\
\hline Rawh & iide School & & D54 & 3.22 & 16 & 6 & & 2 & 1 & 5.79 & 2.98 & .70 & 1.35 & 2.95 & 7.68 & 1.55 & 2.92 \\
\hline Moye & r Springs & & D53 & 2.12 & 11 & 5 & & 1 & 0 & 5.95 & 2.03 & 1.86 & .00 & 2.37 & 6.94 & .98 & 1.99 \\
\hline Rawh & iide School & & D52 & .88 & 4 & 1 & & 0 & 0 & 1.36 & 1.69 & .00 & .00 & 1.85 & 5.09 & .47 & 1.85 \\
\hline Rawh & ide School & & D5 1 & $3: 24$ & 10 & 3 & & 1 & 0 & 4.81 & 3.93 & .96 & .00 & 2.78 & 9.02 & 1.10 & 2.42 \\
\hline Rawh & ide School & & D50 & 1.88 & 6 & 2 & & 1 & 0 & 3.34 & 2.23 & .36 & .00 & 2.21 & 5.89 & 1.09 & 1.89 \\
\hline Gill & ette West & & D49 & 3.41 & 8 & 2 & & 1 & 0 & 5.20 & 1.57 & 2.30 & .00 & 3.16 & 8.35 & 1.35 & 3.03 \\
\hline Gill & ette East & & D48 & .93 & 4 & 1 & & 0 & 0 & 2.69 & 1.32 & .00 & .00 & 2.37 & 5.10 & .51 & 2.29 \\
\hline Gill & ette West & & D47 & 1.38 & 5 & 1 & & 0 & 0 & 2.34 & .36 & .00 & .00 & 1.71 & 5.10 & 1.02 & 1.68 \\
\hline Gill & ette East & & D46B & 8.18 & 13 & 4 & & 2 & 1 & 7.51 & 5.02 & 6.87 & .80 & 6.32 & 14.69 & 1.91 & 6.00 \\
\hline Gill & ette East & & D46 & 2.78 & 6 & 2 & & 1 & 0 & 4.71 & 2.03 & 2.40 & .00 & 3.32 & 8.32 & 1.06 & 3.20 \\
\hline Gill & ette East & & D45 & 1.55 & 5 & 2 & & 0 & 0 & 2.98 & 1.51 & .00 & .00 & 1.26 & 5.92 & .81 & 1.20 \\
\hline Gill & ette East & & D44 & .40 & 2 & 1 & & 0 & 0 & .98 & .55 & .00 & .00 & 1.10 & 2.80 & .41 & 1.05 \\
\hline Gill & ette East & & D43 & 3.33 & 16 & 4 & & 1 & 0 & 7.32 & 4.62 & 2.18 & .00 & 3.89 & 9.52 & 1.20 & 3.76 \\
\hline Gill & ette East & & D42 & 2.13 & 5 & 2 & & 1 & 0 & 1.89 & 1.61 & .67 & .00 & 2.48 & 8.01 & .70 & 2.16 \\
\hline Coyo & te Draw & & D41 & 2.15 & 8 & 2 & & 1 & 0 & 4.31 & 2.83 & .90 & .00 & 2.86 & 6.97 & .87 & 2.58 \\
\hline The & Gap & & D40 & 4.16 & 10 & 3 & & 1 & 0 & 6.55 & 3.25 & 2.28 & .00 & 3.80 & 10.13 & 1.61 & 3.77 \\
\hline Coyo & te Draw & & D39 & 4.45 & 15 & 4 & & 2 & 1 & 8.88 & 2.94 & 1.40 & 1.14 & 4.43 & 12.58 & 1.31 & 3.64 \\
\hline The & Gap & & D38 & 1.04 & 3 & 1 & & 0 & 0 & 1.52 & 1.96 & .00 & .00 & 2.12 & 4.96 & .74 & 2.12 \\
\hline Coyo & te Draw & & D37 & 1.24 & 8 & 3 & & 1 & 0 & 3.56 & 1.04 & 1.38 & .00 & 2.21 & 6.28 & .56 & 2.17 \\
\hline Coyo & te Draw & & D36 & 2.62 & 15 & 4 & & 1 & 0 & 6.91 & 1.75 & 3.21 & .00 & 3.58 & 8.72 & .87 & 3.58 \\
\hline Coyo & te Draw & & D35 & 1.36 & 3 & 1 & & 0 & 0 & 1.81 & 1.59 & .00 & .00 & 2.27 & 5.36 & .77 & 1.55 \\
\hline The & Gap & & D34 & .96 & 2 & 1 & & 0 & 0 & 1.26 & .95 & .00 & .00 & 1.63 & 4.28 & .67 & 1.63 \\
\hline The & Gap & & D33 & 1.08 & 4 & 1 & & 0 & 0 & 2.29 & 1.25 & .00 & .00 & 2.19 & 5.19 & .58 & 2.07 \\
\hline Coyo & te Draw & & D32 & 1.24 & 3 & 1 & & 0 & 0 & 2.50 & .80 & .00 & .00 & 2.04 & 5.00 & .72 & 1.74 \\
\hline Coyo & te Draw & & D31 & 2.50 & 11 & 2 & & 1 & 0 & 6.15 & 1.93 & 2.08 & .00 & 3.34 & 7.77 & .82 & 3.27 \\
\hline Sadd & le Horse B & Butte & D30 & 0.70 & 5 & 2 & & 1 & 0 & 1.64 & 1.04 & .55 & .00 & 1.50 & 3.82 & .67 & 1.34 \\
\hline Sadd & le Horse B & Butte & D29 & 0.40 & 3 & 1 & & 0 & 0 & 1.25 & .60 & .00 & .00 & 1.37 & 3.13 & .44 & 1.03 \\
\hline Sadd & le Horse $B$ & Butte & D28 & 1.37 & 4 & 1 & & 0 & 0 & 2.42 & 2.41 & .00 & .00 & 2.83 & 6.35 & .70 & 2.59 \\
\hline Neil & Butte & & D27 & 3.52 & 3 & 1 & & 0 & 0 & 1.64 & 1.12 & .00 & .00 & 1.54 & 9.44 & 1.51 & .96 \\
\hline Neil & Butte & & D26 & 3.70 & 8 & 1 & & 0 & 0 & 5.86 & 2.35 & .00 & .00 & 2.72 & 10.06 & 1.70 & 2.46 \\
\hline Eagl & e Rode & & D25 & 2.26 & 8 & 2 & & 1 & 0 & 3.25 & 3.99 & .92 & .00 & 3.29 & 7.94 & .81 & 3.01 \\
\hline Neil & Butte & & D24 & 2.14 & 10 & 2 & & 1 & 0 & 3.22 & 1.48 & 2.61 & .00 & 3.56 & 8.31 & .83 & 3.25 \\
\hline Neil & Butte & & D23 & .80 & 7 & 1 & & 0 & 0 & 1.53 & 1.05 & .00 & .00 & 1.37 & 4.28 & .58 & 1.18 \\
\hline Neil & Butte & & D22 & .80 & 3 & 1 & & 0 & 0 & .71 & 1.80 & .00 & .00 & 2.02 & 4.66 & .54 & 2.02 \\
\hline Neil & Butte & & D21 & 1.78 & 9 & 2 & & 1 & 0 & 3.54 & 1.98 & .75 & .00 & 2.32 & 6.05 & 1.32 & 2.10 \\
\hline Neil & Butte & & D20 & .82 & 4 & 1 & & 0 & 0 & .84 & 1.92 & .00 & .00 & 1.97 & 4.31 & .52 & 1.84 \\
\hline Reno & Reservoir & & D19 & 8.84 & 41 & 10 & & 3 & 1 & 15.70 & 6.56 & 6.50 & 5.17 & 6.84 & 14.57 & 1.78 & 6.40 \\
\hline Hili & ght & & D18 & 1.98 & 6 & 2 & & 1 & 0 & 2.27 & 2.43 & .50 & .00 & 2.29 & 6.66 & 1.27 & 2.21 \\
\hline Hili & ght & & D17 & 3.72 & 8 & 2 & & 1 & 0 & 3.37 & .66 & 4.14 & .00 & 4.20 & 9.97 & 1.39 & 3.87 \\
\hline Hili & ght & & D16 & 1.14 & 6 & 1 & & 0 & 0 & 1.92 & 2.28 & .00 & .00 & 2.15 & 5.08 & .72 & 2.05 \\
\hline Hili & ght & & D15 & 1.14 & 6 & 2 & & 1 & 0 & 2.31 & .72 & 1.70 & .00 & 2.18 & 5.97 & .65 & 2.05 \\
\hline Hili & ght & & D14 & 3.26 & 14 & 3 & & 1 & 0 & 5.21 & 3.24 & 1.74 & .00 & 3.30 & 9.84 & 1.10 & 2.86 \\
\hline Open & A Ranch & & D13 & 1.60 & 6 & 2 & & 1 & 0 & 3.04 & 1.78 & .68 & .00 & 2.51 & 6.75 & .76 & 2.46 \\
\hline The & Gap SW & & D11 & 1.65 & 6 & 2 & & 1 & 0 & 2.63 & 1.83 & 1.12 & .00 & 2.58 & 6.49 & .99 & 2.58 \\
\hline Sadd & lle Horse B & Butte & D05 & 2.86 & 11 & 3 & & 1 & 0 & 5.03 & 2.15 & 2.65 & .00 & 4.19 & 8.27 & 1.09 & 3.11 \\
\hline The & Gap SW & & D03 & 3.56 & 3 & 1 & & 0 & 0 & 2.05 & 3.08 & .00 & .00 & 4.40 & 10.17 & 1.13 & 2.85 \\
\hline
\end{tabular}

${ }^{1}$ Name of U.S. Geological Survey $1: 24,000$ topographic map. 


\begin{tabular}{|c|c|c|c|c|c|c|c|c|c|c|c|c|c|}
\hline $\begin{array}{l}\text { Channel } \\
\text { length } \\
\text { (miles) }\end{array}$ & $\begin{array}{r}\text { Basin } \\
\text { relief } \\
\text { (feet) }\end{array}$ & $\begin{array}{l}\text { Used } \\
\text { relief } \\
\text { (feet) }\end{array}$ & $\begin{array}{l}\text { Channel } \\
\text { s lope } \\
\text { (feet } \\
\text { per } \\
\text { foot) }\end{array}$ & $\begin{array}{l}\text { Basin } \\
\text { order }\end{array}$ & $\begin{array}{c}\text { Sinuosity } \\
\text { ratio }\end{array}$ & $\begin{array}{l}\text { Relief } \\
\text { ratio }\end{array}$ & $\begin{array}{l}\text { Total } \\
\text { channel } \\
\text { length } \\
\text { (miles) }\end{array}$ & $\begin{array}{c}\text { Drainage } \\
\text { density } \\
\text { (miles } \\
\text { per } \\
\text { square } \\
\text { mile) }\end{array}$ & $\begin{array}{l}\text { Circu- } \\
\text { larity } \\
\text { ratio }\end{array}$ & $\begin{array}{l}\text { Stream } \\
\text { fre- } \\
\text { quency } \\
\text { (streams } \\
\text { per } \\
\text { square } \\
\text { mile) }\end{array}$ & $\begin{array}{c}\text { Maxi- } \\
\text { mum } \\
\text { side- } \\
\text { slope } \\
\text { relief } \\
\text { (feet) }\end{array}$ & $\begin{array}{c}\text { Side- } \\
\text { slope } \\
\text { dis- } \\
\text { stance } \\
\text { (miles) }\end{array}$ & $\begin{array}{l}\text { Maximum } \\
\text { value } \\
\text { side- } \\
\text { slope } \\
\text { (feet } \\
\text { per } \\
\text { foot) }\end{array}$ \\
\hline 1.66 & 314 & 180 & 0.030 & 3 & 1.10 & 189 & 3.32 & 4.49 & 0.506 & 10.8 & 180 & 0.120 & 0.284 \\
\hline 7.09 & 331 & 132 & .012 & 4 & 1.42 & 62.6 & 27.06 & 3.50 & .571 & 6.2 & 120 & .092 & .247 \\
\hline 1.42 & 184 & 92 & .017 & 2 & 1.13 & 130 & 2.99 & 3.29 & .757 & 4.4 & 60 & .187 & .060 \\
\hline 1.72 & 410 & 122 & .019 & 2 & 1.14 & 246 & 2.70 & 3.81 & .541 & 8.4 & 180 & .137 & .248 \\
\hline 1.66 & 375 & 221 & .036 & 2 & 1.20 & 239 & 2.50 & 4.92 & .481 & 7.8 & 120 & .054 & .420 \\
\hline 3.20 & 403 & 220 & .018 & 4 & 1.09 & 137 & 10.82 & 3.36 & .685 & 7.7 & 120 & .120 & .189 \\
\hline 2.68 & 433 & 119 & .012 & 3 & 1.34 & 183 & 9.84 & 4.65 & .551 & 8.0 & 90 & .096 & .177 \\
\hline 2.01 & 284 & 135 & .018 & 2 & 1.08 & 154 & 3.05 & 3.48 & .424 & 5.7 & 130 & .486 & .050 \\
\hline 2.60 & 276 & 120 & .023 & 3 & 1.07 & 99.3 & 9.70 & 2.99 & .500 & 4.3 & 140 & .403 & .065 \\
\hline 2.21 & 461 & 139 & .017 & 3 & 1.16 & 209 & 5.93 & 3.15 & .680 & 4.7 & 300 & .520 & .109 \\
\hline 3.87 & 441 & 130 & .009 & 3 & 1.27 & 140 & 9.07 & 2.65 & .614 & 3.2 & 140 & .300 & .088 \\
\hline 2.58 & 232 & 120 & .012 & 2 & 1.12 & 97.9 & 4.01 & 4.33 & .447 & 5.3 & 180 & .428 & .079 \\
\hline 1.98 & 194 & 124 & .016 & 2 & 1.17 & 113 & 2.70 & 1.95 & .666 & 4.3 & 100 & .454 & .041 \\
\hline 8.44 & 405 & 148 & .004 & 4 & 1.40 & 64.1 & 20.20 & 2.46 & .476 & 2.4 & 300 & 1.07 & .063 \\
\hline 4.42 & 205 & 85 & .005 & 3 & 1.38 & 61.7 & 9.14 & 3.28 & .504 & 3.2 & 100 & 2.31 & .008 \\
\hline 1.28 & 205 & 152 & .032 & 2 & 1.06 & 163 & 4.49 & 2.89 & .555 & 4.5 & 120 & .320 & .071 \\
\hline 1.12 & 211 & 140 & .033 & 2 & 1.06 & 192 & 1.53 & 3.80 & .644 & 7.4 & 120 & .295 & .077 \\
\hline 4.69 & 312 & 197 & .011 & 3 & 1.24 & 80.2 & 14.12 & 4.24 & .461 & 6.3 & 141 & .340 & .078 \\
\hline 2.35 & 190 & 93 & .010 & 3 & 1.08 & 76.6 & 4.17 & 1.95 & .416 & 3.7 & 170 & .430 & .074 \\
\hline 3.18 & 241 & 135 & .011 & 3 & 1.23 & 84.3 & 8.04 & 3.73 & .555 & 5.1 & 100 & .248 & .076 \\
\hline 4.14 & 443 & 155 & .010 & 3 & 1.09 & 117 & 12.08 & 2.90 & .509 & 3.3 & 100 & .237 & .079 \\
\hline 4.41 & 379 & 152 & .009 & 4 & 1.21 & 85.6 & 14.36 & 3.22 & .353 & 4.9 & 125 & .353 & .067 \\
\hline 2.38 & 289 & 98 & .011 & 2 & 1.12 & 136 & 3.48 & 3.34 & .530 & 3.8 & 160 & .542 & .059 \\
\hline 2.45 & 283 & 136 & .015 & 3 & 1.12 & 128 & 5.98 & 4.82 & .394 & 9.6 & 80 & .302 & .050 \\
\hline 4.70 & 241 & 106 & .006 & 3 & 1.31 & 67 & 11.87 & 4.53 & .432 & 7.6 & 202 & .697 & .054 \\
\hline 2.33 & 176 & 58 & .006 & 2 & 1.50 & 77.5 & 3.40 & 2.50 & .594 & 2.9 & 80 & .349 & .043 \\
\hline 1.79 & 231 & 85 & .012 & 2 & 1.09 & 142 & 2.21 & 2.30 & .657 & 3.1 & 140 & .358 & .074 \\
\hline 2.18 & 252 & 78 & .009 & 2 & 1.05 & 115 & 3.54 & 3.27 & .503 & 4.6 & 192 & .406 & .089 \\
\hline 2.03 & 329 & 113 & .015 & 2 & 1.16 & 162 & 3.30 & 2.66 & .622 & 3.2 & 100 & .423 & .044 \\
\hline 4.01 & 320 & 164 & .011 & 3 & 1.22 & 95.8 & 10.16 & 4.06 & .520 & 5.6 & 160 & .484 & .062 \\
\hline 1.40 & 222 & 116 & .022 & 3 & 1.04 & 148 & 3.23 & 4.61 & .602 & 11.4 & 80 & .178 & .085 \\
\hline 1.10 & 200 & 74 & .018 & 2 & 1.06 & 146 & 1.85 & 4.56 & .519 & 9.8 & 100 & .196 & .099 \\
\hline 3.10 & 240 & 135 & .011 & 2 & 1.19 & 84.8 & 4.83 & 3.52 & .426 & 3.6 & 60 & .199 & .057 \\
\hline 1.38 & 379 & 95 & .018 & 2 & 1.43 & 246 & 2.76 & .78 & .496 & 1.1 & 207 & .396 & .099 \\
\hline 2.92 & 432 & 67 & .006 & 2 & 1.18 & 159 & 8.21 & 2.21 & .459 & 2.4 & 145 & .393 & .069 \\
\hline 3.70 & 429 & 176 & .012 & 3 & 1.22 & 130 & 8.16 & 3.61 & .450 & 1.8 & 252 & .353 & .135 \\
\hline 4.01 & 393 & 130 & .008 & 3 & 1.23 & 110 & 7.31 & 3.41 & .389 & 6.0 & 283 & .540 & 199 \\
\hline 1.31 & 223 & 92 & .019 & 2 & 1.11 & 163 & 2.58 & 3.21 & .550 & 9.9 & 80 & .190 & .079 \\
\hline 2.04 & 134 & 50 & .006 & 2 & 1.00 & 66.3 & 2.51 & 3.15 & .459 & 5.0 & 80 & .230 & .065 \\
\hline 3.03 & 254 & 70 & .006 & 3 & 1.44 & 109 & 6.27 & 3.52 & 610 & 6.7 & 80 & .232 & .065 \\
\hline 2.13 & 204 & 92 & .009 & 2 & 1.15 & 104 & 2.76 & 3.36 & .555 & 6.0 & 90 & .310 & .054 \\
\hline 9.67 & 274 & 100 & .002 & 4 & 1.51 & 40.1 & 33.93 & 3.83 & .523 & 6.2 & 120 & .530 & .042 \\
\hline 2.60 & 191 & 107 & .011 & 3 & 1.17 & 83.4 & 5.20 & 2.62 & .560 & 4.5 & 100 & .234 & .080 \\
\hline 5.00 & 390 & 210 & .011 & 3 & 1.29 & 92.9 & 8.17 & 2.19 & .470 & 2.9 & 217 & .619 & .066 \\
\hline 2.43 & 276 & 172 & .019 & 2 & 1.18 & 128 & 4.20 & 3.68 & .554 & 6.1 & 110 & .509 & .040 \\
\hline 2.53 & 165 & 89 & .009 & 3 & 1.23 & 75.7 & 4.73 & 4.14 & .401 & 7.8 & 190 & .267 & .134 \\
\hline 3.65 & 232 & 156 & .011 & 3 & 1.27 & 70.3 & 10.19 & 3.12 & .422 & 5.5 & 110 & .425 & .049 \\
\hline 2.76 & 259 & 125 & .012 & 3 & 1.12 & 103 & 5.50 & 3.43 & .441 & 5.6 & 200 & .283 & .133 \\
\hline 2.96 & 296 & 160 & .014 & 3 & 1.14 & 115 & 5.58 & 3.38 & .492 & 5.45 & 150 & .280 & .101 \\
\hline 4.19 & 342 & 132 & .008 & 3 & 1.34 & 81.6 & 9.88 & 3.45 & .525 & 5.24 & 110 & .065 & .320 \\
\hline 3.17 & 402 & 112 & .009 & 2 & 1.11 & 91.4 & 5.13 & 1.44 & .432 & 1.12 & 230 & .820 & .053 \\
\hline
\end{tabular}




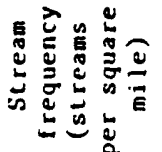

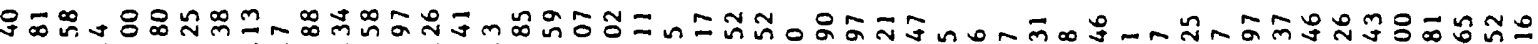

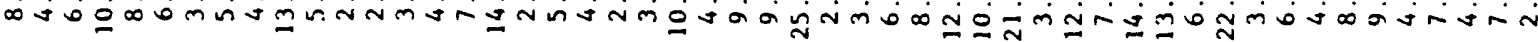

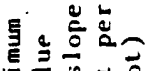

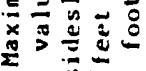

主是:

品范

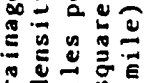
苛它

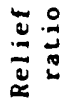

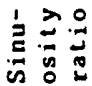

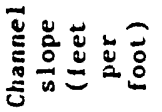

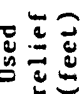

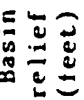

范

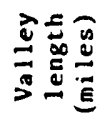

도옹

造总

昰高

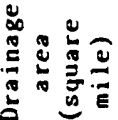

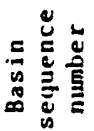

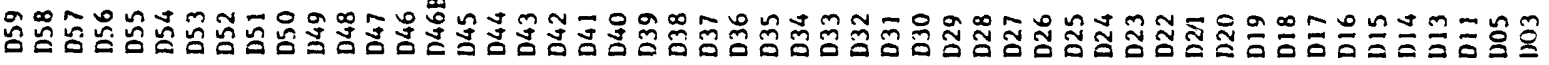

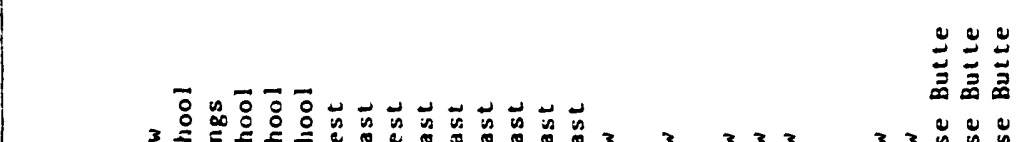

के

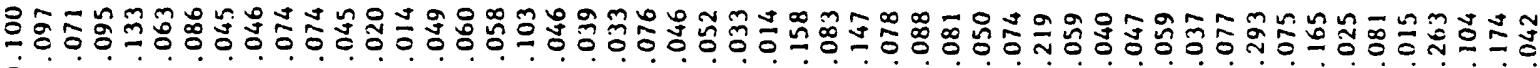

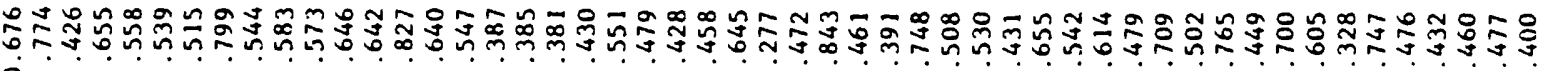

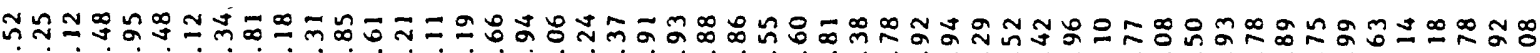

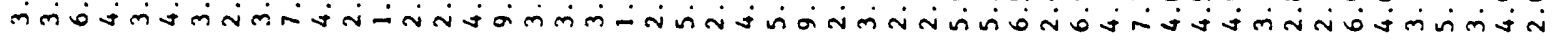

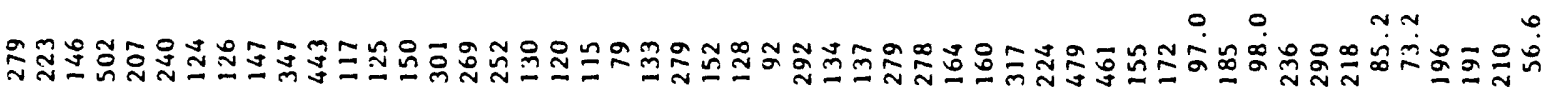

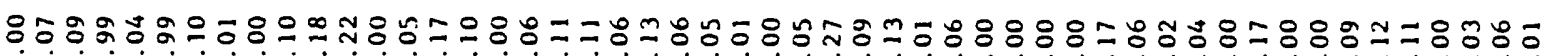

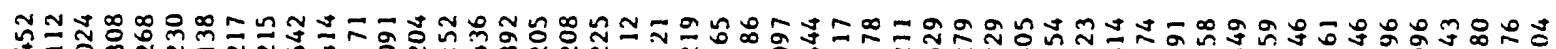

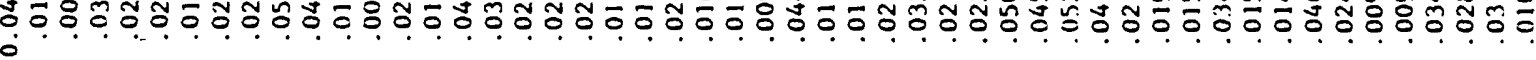

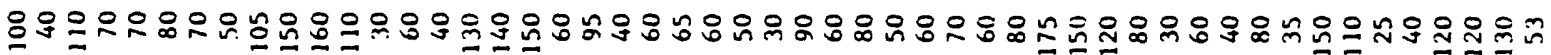

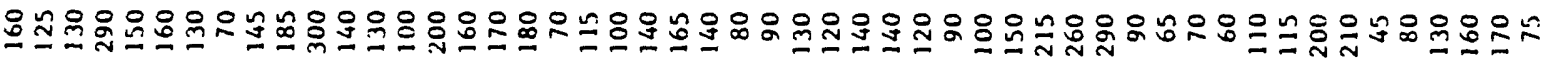

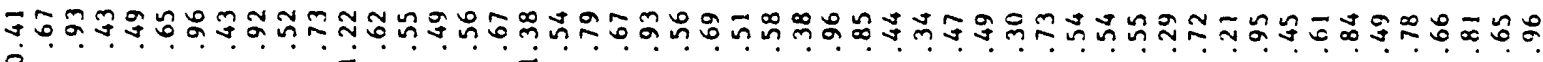
0

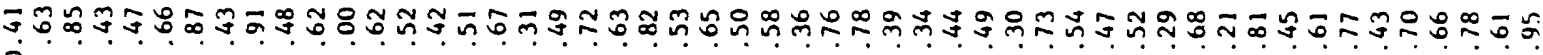

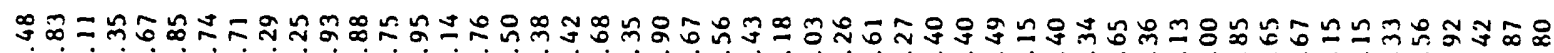

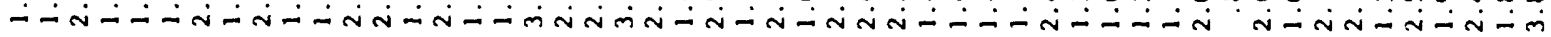

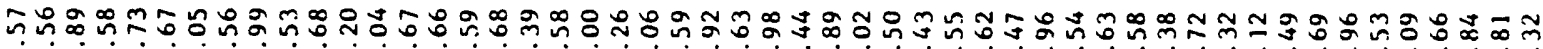
(

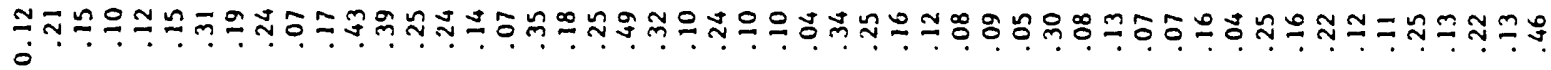
$\circ$

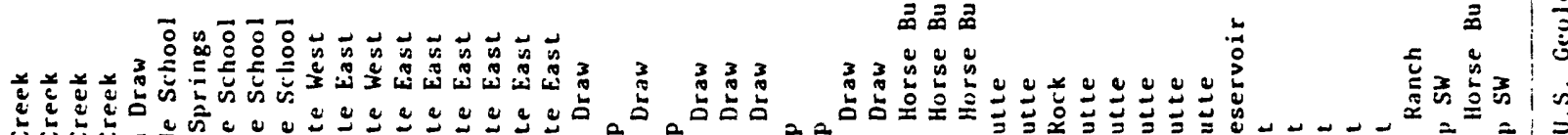

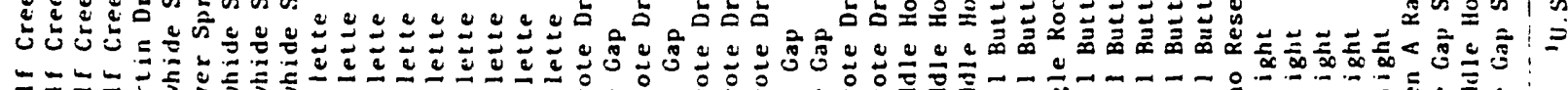

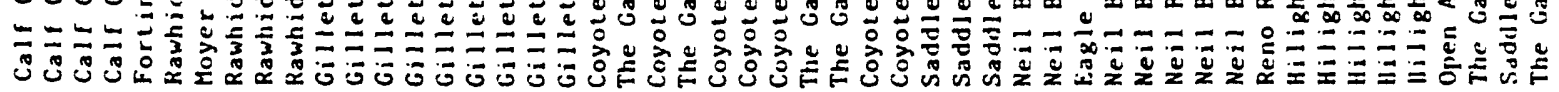


Table 17.--statistical properties for first-order basins

[Number of basins in sample $=51$ ]

\begin{tabular}{|c|c|c|c|c|c|c|}
\hline \multirow[t]{2}{*}{ Characteristic } & \multirow[t]{2}{*}{ Minimum } & \multirow[t]{2}{*}{ Maximum } & \multirow[t]{2}{*}{$\begin{array}{l}\text { Arith- } \\
\text { metic } \\
\text { mean }\end{array}$} & \multirow[t]{2}{*}{$\begin{array}{l}\text { Geo- } \\
\text { metric } \\
\text { mean }\end{array}$} & \multicolumn{2}{|c|}{$\begin{array}{c}\text { Standard } \\
\text { deviation of } \\
\text { geometric mean, } \\
\text { in percent }\end{array}$} \\
\hline & & & & & Minus & Plus \\
\hline Drainage area (square miles) & 0.04 & 0.49 & 0.19 & 0.16 & 46.7 & 87.7 \\
\hline Basin length (miles) & .32 & 1.39 & .76 & .72 & 28.8 & 40.5 \\
\hline Basin perimeter (miles) & .85 & 3.81 & 2.02 & 1.92 & 27.8 & 38.6 \\
\hline Valley length (miles) & .22 & 1.31 & .61 & .58 & 29.1 & 41.1 \\
\hline Channel length (miles) & .22 & 1.38 & .65 & .61 & 30.6 & 44.0 \\
\hline Basin relief (feet) & 45.0 & 300 & 140 & 129 & 34.3 & 51.9 \\
\hline Used relief (feet) & 25.0 & 175 & 82.2 & 72.8 & 39.8 & 66.2 \\
\hline $\begin{array}{l}\text { Channel slope (feet } \\
\text { per foot) }\end{array}$ & .009 & .054 & .026 & .023 & 50.6 & 102 \\
\hline Sinuosity ratio & 1.00 & 1.28 & 1.06 & 1.06 & 5.9 & 6.26 \\
\hline Relief ratio & 56.6 & 502 & 204 & 180 & 39.6 & 66.0 \\
\hline $\begin{array}{l}\text { Total channel length } \\
\text { (miles) }\end{array}$ & .217 & 1.38 & .650 & .610 & 30.6 & 44.0 \\
\hline $\begin{array}{l}\text { Drainage density } \\
\text { (miles per square miles) }\end{array}$ & 1.37 & 9.66 & 4.26 & 3.90 & 34.7 & 52.9 \\
\hline Circularity ratio & .277 & .843 & .551 & .535 & 21.2 & 28.5 \\
\hline $\begin{array}{l}\text { Maximum value sideslope } \\
\text { (feet per foot) }\end{array}$ & .014 & .293 & .081 & .065 & 49.1 & 96.6 \\
\hline
\end{tabular}


Table 18.--Statistical properties for second-order basins

[Number of basins in sample $=22$ ]

\begin{tabular}{|c|c|c|c|c|c|c|}
\hline \multirow[t]{2}{*}{ Characteristic } & \multirow[t]{2}{*}{ Minimum } & \multirow[t]{2}{*}{ Maximum } & \multirow[t]{2}{*}{$\begin{array}{l}\text { Arith- } \\
\text { metic } \\
\text { mean }\end{array}$} & \multirow[t]{2}{*}{$\begin{array}{l}\text { Geo- } \\
\text { metric } \\
\text { mean }\end{array}$} & \multicolumn{2}{|c|}{$\begin{array}{l}\text { Standard } \\
\text { deviation of } \\
\text { geometric mean, } \\
\text { in percent } \\
\end{array}$} \\
\hline & & & & & Minus & Plus \\
\hline $\begin{array}{l}\text { Drainage area (square miles) } \\
\text { Basin length (miles) } \\
\text { Basin perimeter (miles) } \\
\text { Basin width (miles) } \\
\text { Valley length (miles) }\end{array}$ & $\begin{array}{r}0.40 \\
1.10 \\
2.80 \\
.41 \\
.96\end{array}$ & $\begin{aligned} 3.70 \\
4.40 \\
10.2 \\
1.70 \\
2.85\end{aligned}$ & $\begin{array}{r}1.32 \\
1.98 \\
5.36 \\
.74 \\
1.74\end{array}$ & $\begin{array}{r}1.09 \\
1.89 \\
5.06 \\
.69 \\
1.66\end{array}$ & $\begin{array}{l}45.5 \\
26.7 \\
28.3 \\
32.1 \\
26.9\end{array}$ & $\begin{array}{l}83.3 \\
36.4 \\
39.5 \\
47.3 \\
36.7\end{array}$ \\
\hline $\begin{array}{l}\text { Channel length (miles) } \\
\text { Basin relief (feet) } \\
\text { Used relief (feet) } \\
\text { Channel slope (feet } \\
\text { per foot) }\end{array}$ & $\begin{array}{l}1.10 \\
134 \\
50.0 \\
.006\end{array}$ & $\begin{array}{l}3.17 \\
432 \\
124 \\
.037\end{array}$ & $\begin{array}{l}2.00 \\
266 \\
116 \\
\quad .016\end{array}$ & $\begin{array}{l}1.91 \\
254 \\
107 \\
.015\end{array}$ & $\begin{array}{l}26.9 \\
27.0 \\
33.1 \\
39.3\end{array}$ & $\begin{array}{l}36.9 \\
37.0 \\
49.4 \\
64.7\end{array}$ \\
\hline $\begin{array}{l}\text { Sinuosity ratio } \\
\text { Relief ratio } \\
\text { Total channel length (miles) } \\
\text { Drainage density } \\
\quad \text { (miles per square mile) }\end{array}$ & $\begin{array}{c}1.01 \\
66.3 \\
1.53 \\
.784\end{array}$ & $\begin{array}{r}1.50 \\
246 \\
8.21 \\
4.92\end{array}$ & $\begin{array}{l}1.16 \\
143 \\
3.40 \\
3.12\end{array}$ & $\begin{array}{r}1.15 \\
135 \\
3.17 \\
2.92\end{array}$ & $\begin{array}{l}8.81 \\
30.3 \\
30.6 \\
33.5\end{array}$ & $\begin{array}{l}9.65 \\
43.5 \\
44.2 \\
50.6\end{array}$ \\
\hline $\begin{array}{l}\text { Circularity ratio } \\
\text { Stream frequency } \\
\text { (streams per square mile) }\end{array}$ & $\begin{array}{l}.424 \\
1.12\end{array}$ & $\begin{array}{l}.757 \\
9.96\end{array}$ & $\begin{array}{l}.540 \\
5.06\end{array}$ & $\begin{array}{l}.533 \\
4.41\end{array}$ & $\begin{array}{l}14.8 \\
44.3\end{array}$ & $\begin{array}{l}17.3 \\
79.6\end{array}$ \\
\hline $\begin{array}{l}\text { Maximum sideslope relief } \\
\text { (feet) } \\
\text { Sideslope distance (miles) }\end{array}$ & 60.0 & 230 & 127 & 118 & 31.7 & 46.5 \\
\hline $\begin{array}{l}\text { Maximum value sideslope } \\
\text { (feet per foot) }\end{array}$ & .041 & .421 & .090 & .073 & 42.5 & 74.0 \\
\hline $\begin{array}{l}\text { Average channel length for } \\
\text { first-order basins } \\
\text { (miles) }\end{array}$ & .210 & 8.37 & .511 & .471 & 35.6 & 55.4 \\
\hline $\begin{array}{l}\text { Average channel length for } \\
\text { second-order basins } \\
\text { (miles) }\end{array}$ & .360 & 3.08 & 1.40 & 1.21 & 44.0 & 78.5 \\
\hline
\end{tabular}


Table 19.--Statistical properties for third-order basins

[Number of basins in sample $=24$ ]

\begin{tabular}{|c|c|c|c|c|c|c|}
\hline \multirow[t]{2}{*}{ Characteristic } & \multirow[t]{2}{*}{ Minimum } & \multirow[t]{2}{*}{ Maximum } & \multirow[t]{2}{*}{$\begin{array}{l}\text { Arith- } \\
\text { metic } \\
\text { mean }\end{array}$} & \multirow[t]{2}{*}{$\begin{array}{l}\text { Geo- } \\
\text { metric } \\
\text { mean }\end{array}$} & \multicolumn{2}{|c|}{$\begin{array}{l}\text { Standard } \\
\text { deviation of } \\
\text { geometric mean, } \\
\text { in percent } \\
\end{array}$} \\
\hline & & & & & Minus & Plus \\
\hline Drainage area (square miles) & 0.70 & 4.16 & 2.31 & 2.11 & 37.3 & 59.4 \\
\hline Basin length (mịles) & 1.50 & 4.20 & 2.90 & 2.80 & 24.1 & 31.8 \\
\hline Basin perimeter (miles) & 3.82 & 10.1 & 7.51 & 7.31 & 21.9 & 28.1 \\
\hline Basin width (miles) & .47 & 1.61 & .98 & .94 & 26.3 & 35.8 \\
\hline Valley length (miles) & 1.34 & 3.87 & 2.67 & 2.58 & 24.9 & 33.1 \\
\hline Channel length (miles) & 1.40 & 5.00 & 3.28 & 3.13 & 28.2 & 39.2 \\
\hline Basin relief (feet) & 165 & 461 & 306 & 292 & 26.2 & 35.5 \\
\hline Used relief (feet) & 70.0 & 210 & 135 & 130 & 23.8 & 31.2 \\
\hline $\begin{array}{l}\text { Channel slope (feet } \\
\text { per foot) }\end{array}$ & .005 & .303 & .012 & .011 & 31.8 & 46.6 \\
\hline Sinuosity ratio & 1.04 & 1.44 & 1.22 & 1.21 & 8.24 & 8.98 \\
\hline Relief ratio & 61.7 & 209 & 110 & 104 & 28.3 & 39.4 \\
\hline Total channel length (miles) & 3.23 & 14.1 & 7.82 & 7.27 & 33.0 & 49.4 \\
\hline $\begin{array}{l}\text { Drainage density } \\
\quad \text { (miles per square mile) }\end{array}$ & 1.96 & 4.82 & 3.54 & 3.45 & 21.0 & 26.6 \\
\hline Circularity ratio & .389 & .681 & .501 & .495 & 13.1 & 16.5 \\
\hline $\begin{array}{l}\text { Stream frequency } \\
\text { (streams per square mile) }\end{array}$ & 2.96 & 11.4 & 5.93 & 5.53 & 31.3 & 45.4 \\
\hline $\begin{array}{l}\text { Maximum sideslope relief } \\
\text { (feet) }\end{array}$ & 80.0 & 300 & 153 & 141 & 33.4 & 50.1 \\
\hline Sideslope distance (miles) & .065 & 2.31 & .415 & .316 & 50.8 & 103 \\
\hline $\begin{array}{l}\text { Maximum value sideslope } \\
\text { (feet per foot) }\end{array}$ & .008 & .320 & .108 & .087 & 51.1 & 104 \\
\hline $\begin{array}{l}\text { Average channel length for } \\
\text { first-order basins } \\
\text { (miles) }\end{array}$ & .284 & .785 & .467 & .453 & 21.5 & 27.3 \\
\hline $\begin{array}{l}\text { Average channel length for } \\
\text { second-order basins } \\
\text { (miles) }\end{array}$ & .330 & 2.00 & .884 & .797 & 38.3 & 62.1 \\
\hline $\begin{array}{l}\text { Average channel length for } \\
\text { third-order basins } \\
\text { (miles) }\end{array}$ & .360 & 4.14 & 1.61 & 1.32 & 48.8 & 95.4 \\
\hline
\end{tabular}


Table 20.--Statistical properties for fourth-order basins

[Number of basins in sample $=5$ ]

\begin{tabular}{|c|c|c|c|c|c|c|}
\hline \multirow[t]{2}{*}{ Characteristic } & \multirow[t]{2}{*}{ Minimum } & \multirow[t]{2}{*}{ Maximum } & \multirow[t]{2}{*}{$\begin{array}{l}\text { Arith- } \\
\text { metic } \\
\text { mean }\end{array}$} & \multirow[t]{2}{*}{$\begin{array}{l}\text { Geo- } \\
\text { metric } \\
\text { mean }\end{array}$} & \multicolumn{2}{|c|}{$\begin{array}{l}\text { Standard } \\
\text { deviation of } \\
\text { geometric mean, } \\
\text { in percent } \\
\end{array}$} \\
\hline & & & & & Minus & Plus \\
\hline Drainage area (square miles) & 3.22 & 8.84 & 6.48 & 6.04 & 35.8 & 55.8 \\
\hline Basin length (miles) & 2.95 & 6.84 & 5.17 & 4.96 & 28.5 & 39.8 \\
\hline Basin perimeter (miles) & 7.68 & 14.7 & 12.5 & 12.2 & 23.4 & 30.6 \\
\hline Basin width (miles) & 1.31 & 1.97 & 1.70 & 1.68 & 15.5 & 18.3 \\
\hline Valley length (miles) & 2.92 & 6.40 & 4.79 & 4.59 & 28.4 & 39.7 \\
\hline Channel length (miles) & 3.20 & 9.67 & 6.56 & 6.06 & 37.1 & 59.1 \\
\hline Basin relief (feet) & 274 & 405 & 358 & 355 & 15.3 & 18.0 \\
\hline Used relief (feet) & 100 & 220 & $150 \quad 1$ & 146 & 24.7 & 32.9 \\
\hline $\begin{array}{l}\text { Channel slope (feet } \\
\text { per foot) }\end{array}$ & .003 & .019 & .010 & .008 & 53.3 & 114 \\
\hline Sinuosity ratio & 1.10 & 1.51 & 1.33 & 1.32 & 12.4 & 14.2 \\
\hline Relief ratio & 40.0 & 137 & 77.8 & 71.6 & 36.4 & 57.1 \\
\hline Total channel length (miles) & 10.8 & 33.9 & 21.3 & 19.6 & 36.9 & 58.5 \\
\hline $\begin{array}{l}\text { Drainage density } \\
\quad(\text { miles per square mile) }\end{array}$ & 2.47 & 3.83 & 3.28 & 3.24 & 15.3 & 18.0 \\
\hline Circularity ratio & .353 & .680 & .522 & .510 & 21.8 & 27.8 \\
\hline $\begin{array}{l}\text { Stream frequency } \\
\text { (streams per square mile) }\end{array}$ & 2.44 & 7.76 & 5.52 & 5.15 & 36.0 & 56.2 \\
\hline $\begin{array}{l}\text { Maximum sideslope relief } \\
(\text { feet })\end{array}$ & 120 & 300 & 157 & 145 & 33.3 & 50.0 \\
\hline Sideslope distance (miles) & .092 & 1.07 & .433 & .294 & 64.1 & 179 \\
\hline $\begin{array}{l}\text { Maximum value sideslope } \\
\text { (feet per foot) }\end{array}$ & .043 & .247 & .121 & .097 & 53.2 & 113 \\
\hline $\begin{array}{l}\text { Average channel length for } \\
\text { first-order basins } \\
\text { (miles) }\end{array}$ & .353 & .592 & .454 & .441 & 22.8 & 29.5 \\
\hline $\begin{array}{l}\text { Average channel length for } \\
\text { second-order basins } \\
\text { (miles) }\end{array}$ & .497 & 1.26 & 7.67 & .730 & 28.7 & 40.2 \\
\hline $\begin{array}{l}\text { Average channel length for } \\
\text { third-order basins } \\
\text { (miles) }\end{array}$ & .350 & 3.44 & 1.66 & 1.25 & 60.0 & 150 \\
\hline $\begin{array}{l}\text { Average channel length for } \\
\text { fourth-order basins } \\
\text { (miles) }\end{array}$ & .800 & 5.17 & 2.52 & 1.92 & 56.3 & 128 \\
\hline
\end{tabular}




\begin{tabular}{|c|c|c|}
\hline & 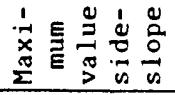 & $\stackrel{8}{8}$ \\
\hline & 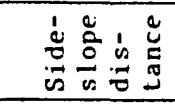 & $\stackrel{8}{\stackrel{\infty}{\sim}} \stackrel{0}{i}$ \\
\hline & 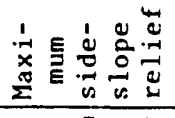 & 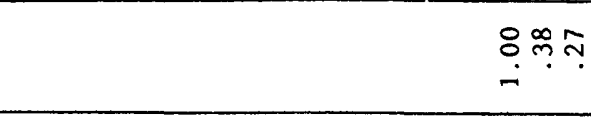 \\
\hline & 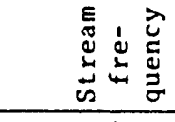 & 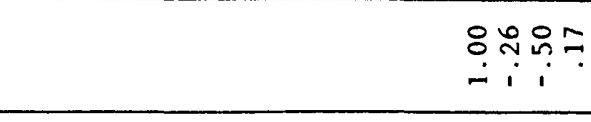 \\
\hline & 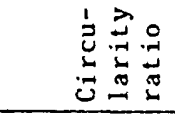 & 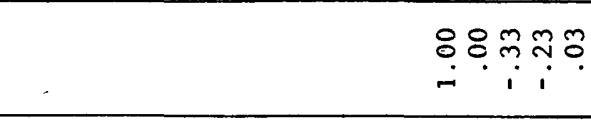 \\
\hline & 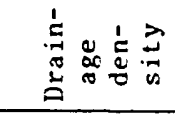 & 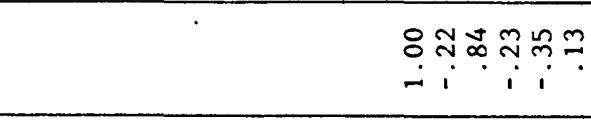 \\
\hline & 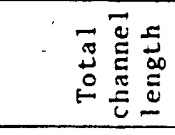 & 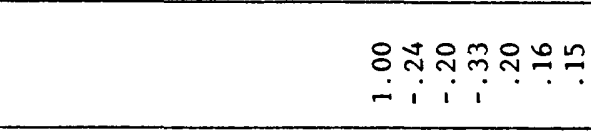 \\
\hline 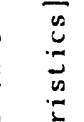 & 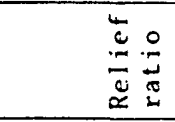 & 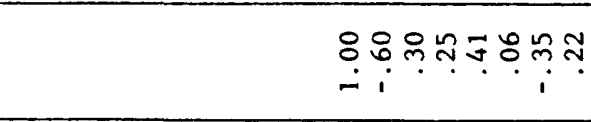 \\
\hline 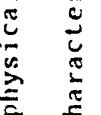 & 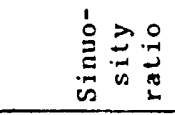 & 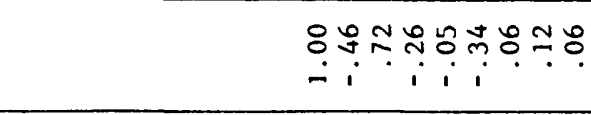 \\
\hline$\check{c}$ & 息 & 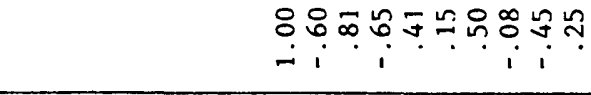 \\
\hline 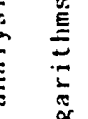 & 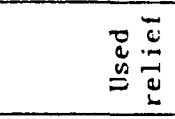 & \&̊ㅇํำ \\
\hline$\stackrel{0}{E}_{\tilde{v}}^{\infty}$ & 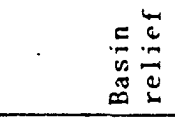 & 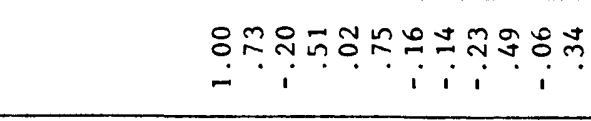 \\
\hline 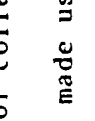 & 至 & 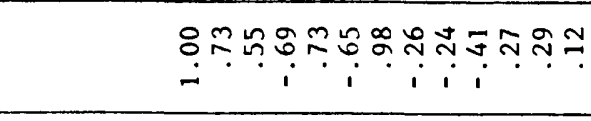 \\
\hline 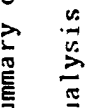 & 党志 & 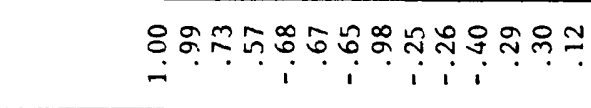 \\
\hline$\underline{\Sigma}$ & 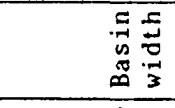 & 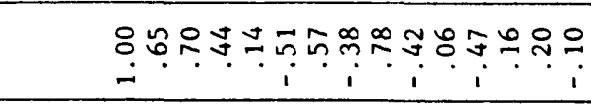 \\
\hline & 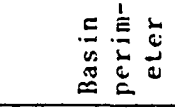 & 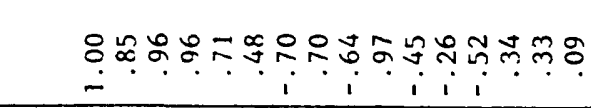 \\
\hline & 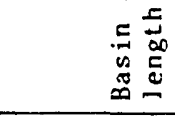 & 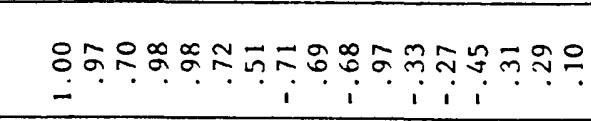 \\
\hline & 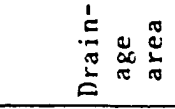 & 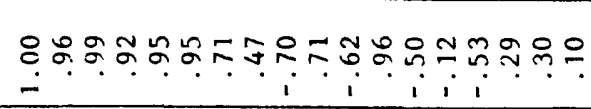 \\
\hline & & $\begin{array}{ll} & \\
& \end{array}$ \\
\hline
\end{tabular}




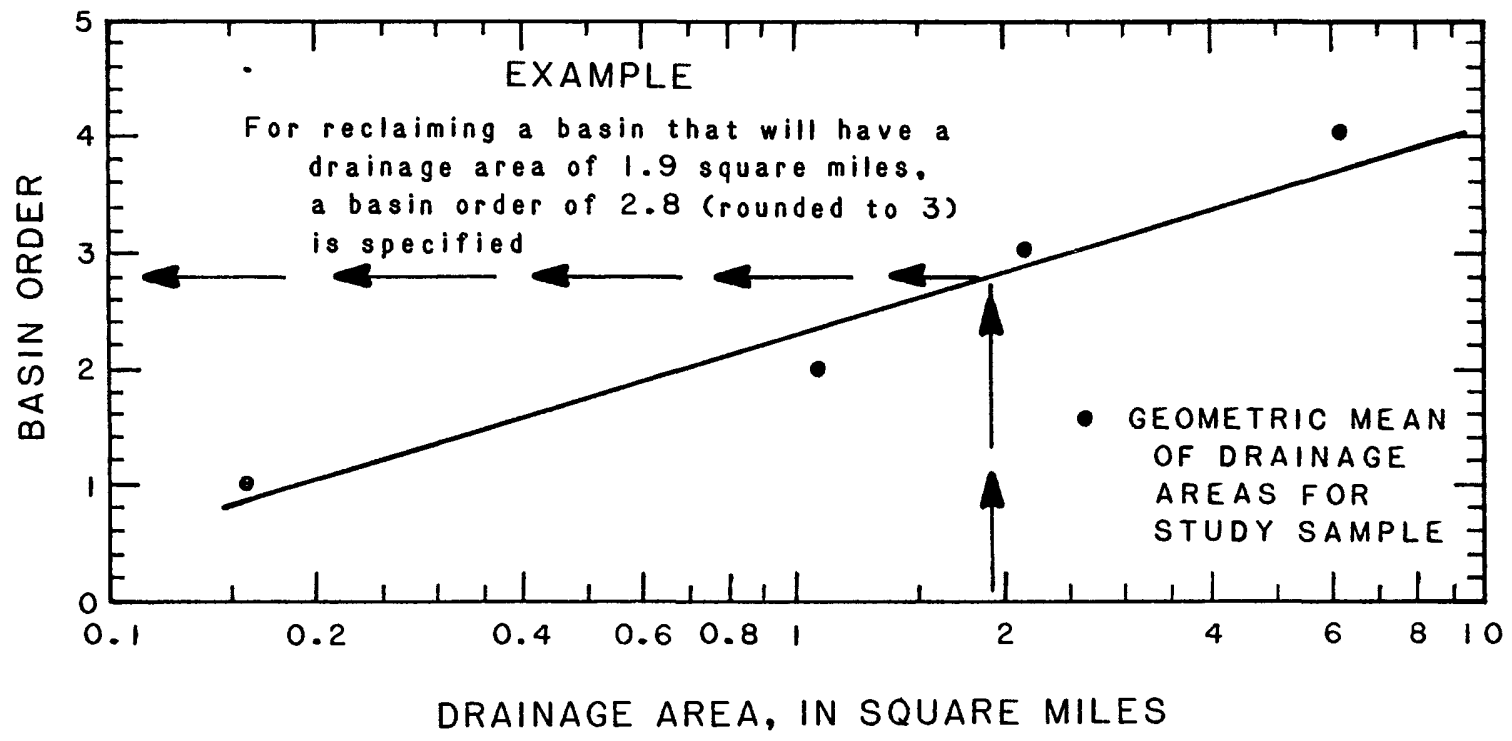

Figure 15.--Relation of basin order to drainage area. 


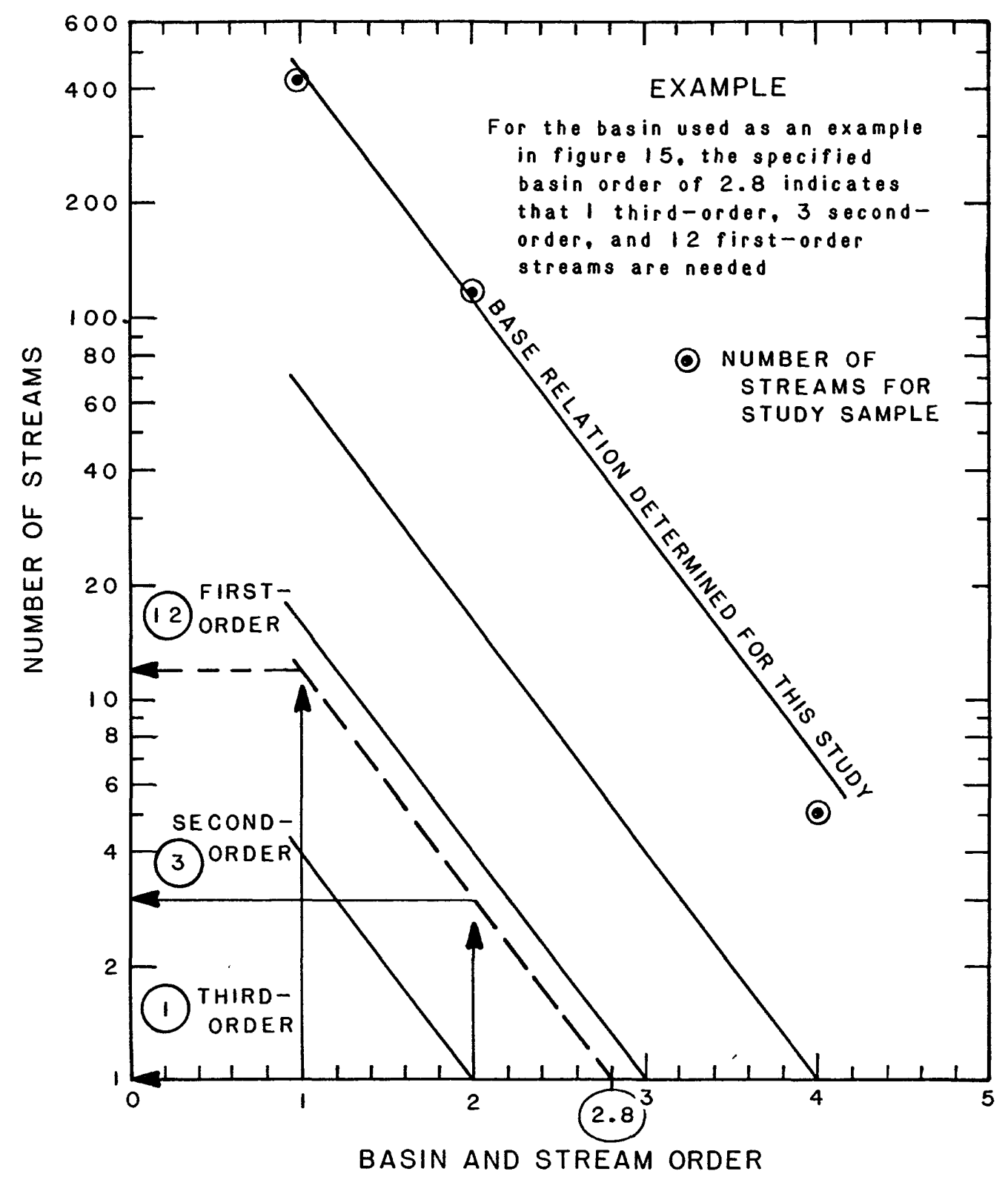

Figure 16.--Relation of number of streams to basin order. 


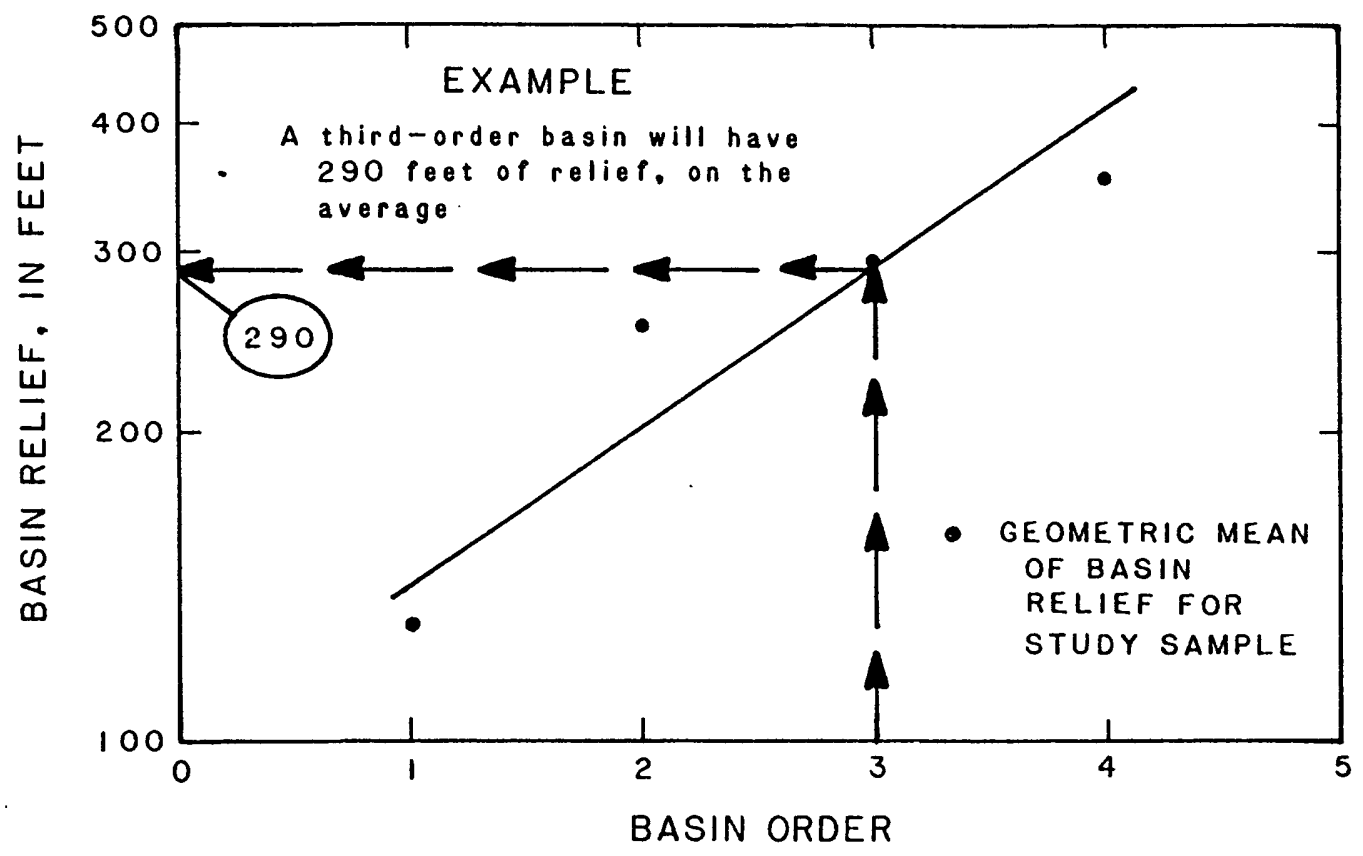

Figure 17.--Relation of basin relief to basin order. 


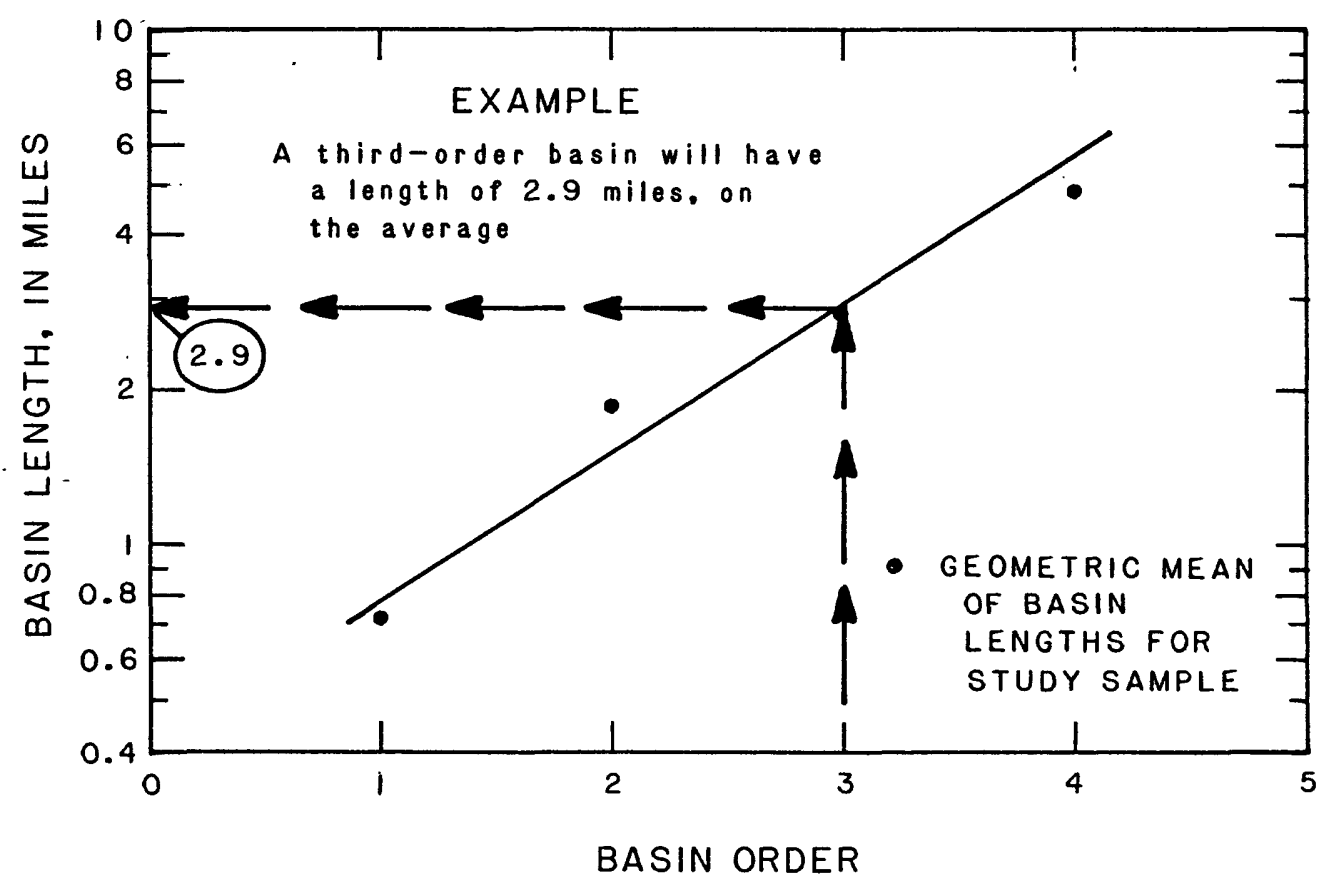

Figure 18.--Relation of basin length to basin order. 


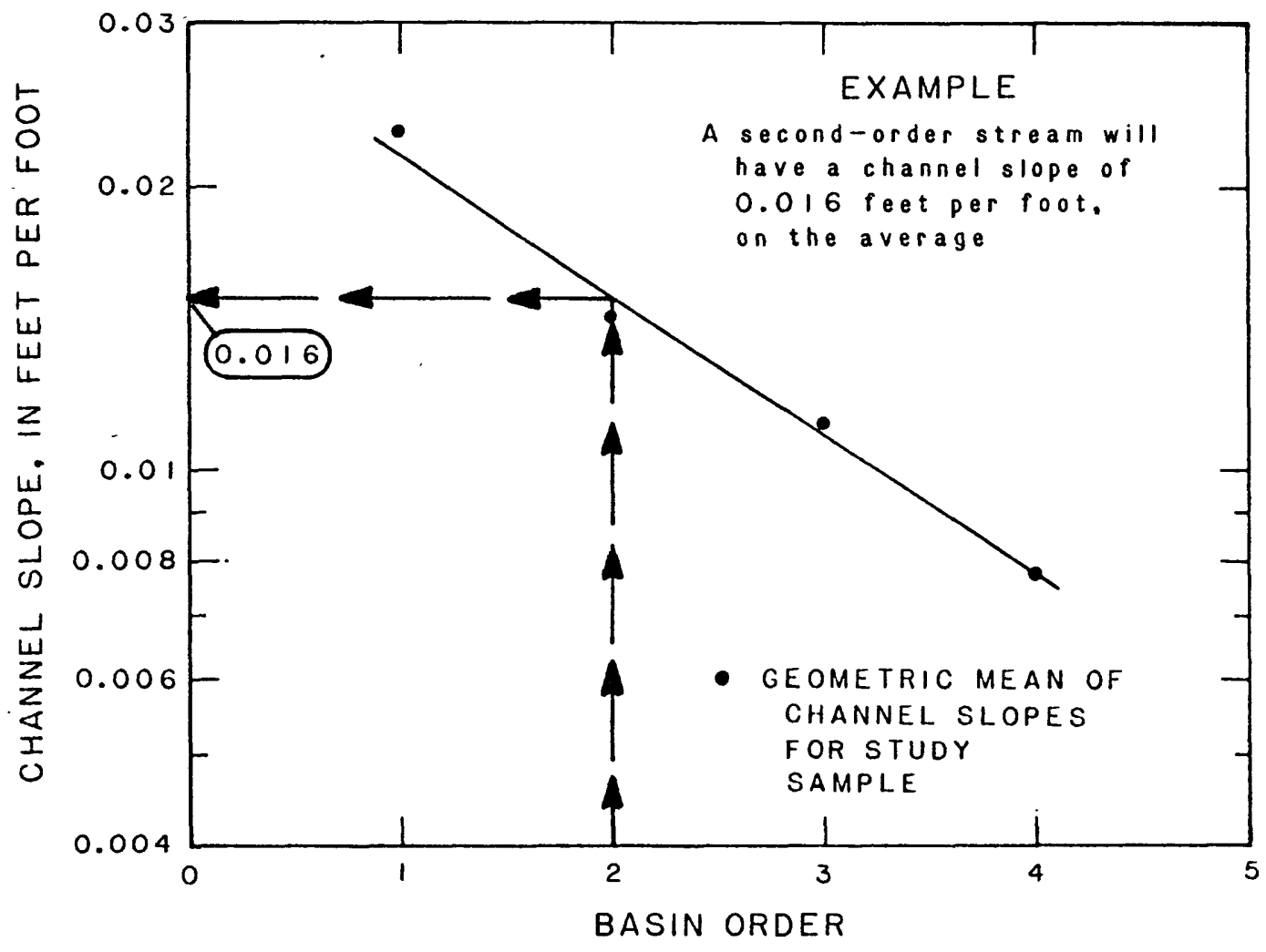

Figure 19.--Relation of channel slope to basin order. 


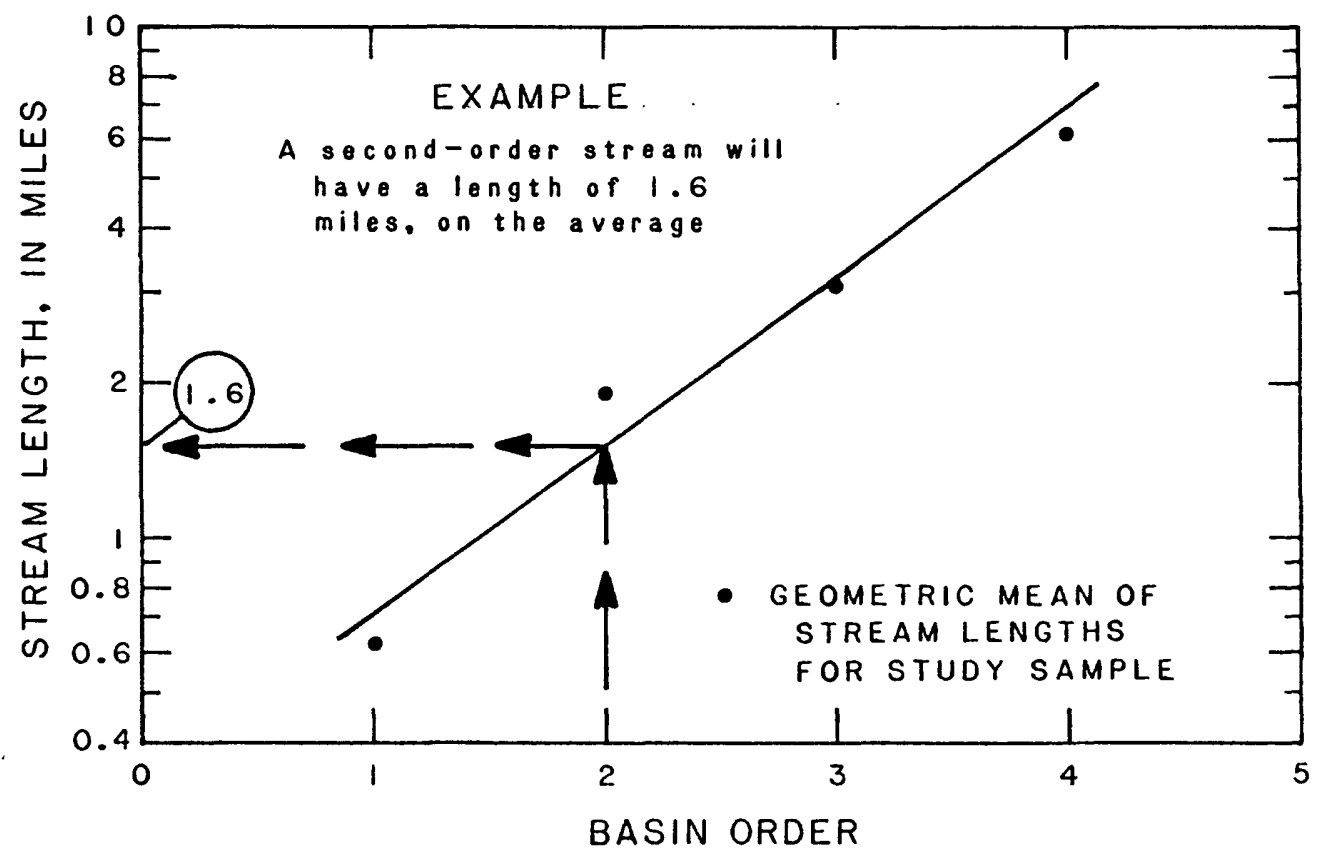

Figure 20.--Relation of stream length to basin order. 


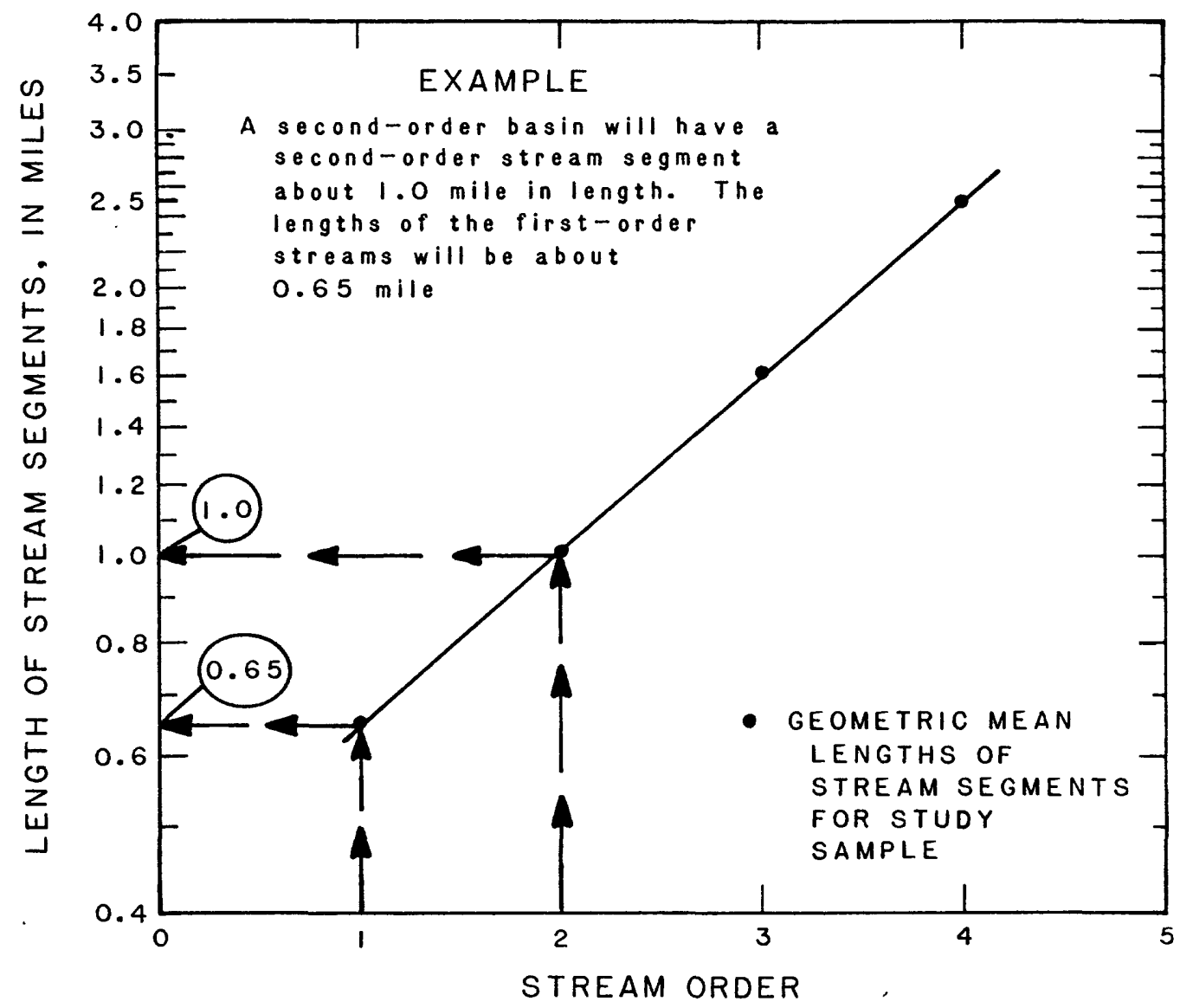

Figure 21.--Relation of stream length of the segments of a given order to stream order. 
Table 22.--Summary of regression analysis

[Abbreviations: $\mathrm{BL}$, basin length in miles; AREA, drainage area, in square miles; RELIEF, basin relief, in feet; CHAN-L, length of main channel, in miles; CHAN-S, average slope of main channel, in feet per foot; and CL-TOTAL, total length of channels in miles]

\begin{tabular}{|c|c|c|c|c|}
\hline \multirow{2}{*}{ Regression equation } & \multirow{2}{*}{$\begin{array}{l}\text { Correlation } \\
\text { coefficient } \\
\text { (R) }\end{array}$} & \multicolumn{3}{|c|}{ Standard error of estimate (SE) } \\
\hline & & Log units & Average & Percent \\
\hline $\mathrm{BL}=1.85 \mathrm{AREA}^{0.51}$ & 0.96 & 0.091 & -18.9 & +23.3 \\
\hline RELIEF $=227 \mathrm{AREA}^{0.28}$ & .71 & .164 & -31.5 & +23.3 \\
\hline RELIEF $=163 \mathrm{BL}^{0.52}$ & .72 & .163 & -31.3 & -45.5 \\
\hline$U R=2.56$ RELIEF 0.69 & .74 & .144 & -28.2 & +39.3 \\
\hline $\mathrm{CHAN}-\mathrm{L}=0.92 \mathrm{BL}^{1} .16$ & .98 & .066 & -14.1 & +16.4 \\
\hline $\mathrm{CHAN}-\mathrm{S}=0.0036 \mathrm{BL}^{-0.89} \mathrm{UR}^{0.90}$ & .96 & .072 & -15.3 & +18.0 \\
\hline CL-TOTAL $=1.15 \mathrm{BL}^{1.64}$ & .97 & .135 & -26.7 & +36.5 \\
\hline CL-TOTAL $=3.22$ AREA $^{0.86}$ & .96 & .147 & -28.7 & +40.3 \\
\hline
\end{tabular}

\section{Illustrative Example}

An example using the previously described graphs and relations considers a basin of $1.9 \mathrm{mi}^{2}$ that has been either partly or wholly mined. The area is a headwater basin, with no major stream flowing from upstream through the mined area. The data in figure 15 indicate that, based on the relation of basin order to drainage area for the study sample, a basin order of 2.8 is necessary to drain the area. The figure 2.8 rounds to the whole number 3 , indicating the main channel flowing from the basin needs to be a third-order stream. Based on the relative numbers of streams in various orders for the study sample, the data in figure 16 indicate that for the basin order of 2.8 indicated by figure 15, 1 third-order, 3 second-order, and 12 first-order streams also are necessary to complete the drainage network. The data in figures 17 through 21 and the relations listed in table 22 can be similarly used to aid in the design of a stable drainage network for a reclaimed basin.

During the design process, certain constraints of the mined area probably will require deviation from the values indicated by the graphs and relations. For example, after designing a tentative network of channels, the actual length or relief of the mined area may be different from the values indicated by figures 17 and 18 . The standard deviations in tables 17 through 20 and the standard errors of estimate in table 22 can be used as guides in determining how much deviation could be made from the values indicated-by the relations. For the purposes of erosional stability, a basin relief somewhat lower than indicated by the relations should cause no problem. However, if a higher relief is desired, limiting the design value to a magnitude within one standard deviation larger than the predicated value seems to be a logical criterion. 


\section{Evaluation of Basin Stability}

The results of a hypsometric analysis evaluating the stability of natural basins can be used to help design reconstructed basins that approximate stable natural basins. Hypsometric analysis provides a quantitative description of the distribution of mass within a basin from the base, or low point of the basin, to the top, or high point of the basin (Strahler, 1952, 1964). A hypsometric analysis was made for second- and higher order basins of the study sample. The average hypsometric curve for the respective basin order is shown in figures 22-24. The curves show the relative area that exists at various heights within the basin from measurements of the area between successive land-surface contours on a topographic map.

The shape of a hypsometric curve provides a representation of the erosional development of a drainage basin in time (Schumm, 1977, p. 68). During erosion of a basin, the shape of the hypsometric curve will change from convex upward to virtually straight and then to concave upward (Schumm, 1977, p. 70). Such changes indicate that with time the zone of maximum erosion migrates toward the head of the basin. The concave-upward shape of the hypsometric curves for all three basin orders indicates the basins have reached a state in their geomorphic development where further development will be relatively slow. Therefore, the basins may be considered to be relatively stable.

The data in figures 22-24 can be used to help design the placement of material within a mined basin to approximate natural landscapes based on the average of the basins studied. If constraints in the reconstruction require a deviation from the average curves, staying within one standard deviation from the predicited value used to construct the curves seems to be a logical criteria. A review of the means and standard deviations of the hypsometric sample data indicates that the variability of mass distribution decreases with increasing stream order. That is, the standard deviation of the data for fourth-order basins is less than that for third-order basins, and so forth. This may be partly due to the smaller sample size used for the increasing basin orders. However, it is largely because the larger basins have the magnitude of streamflow and associated power necessary to reach a base level of equilibrium despite inequalities in surface structure.

\section{Application of Geomorphic Relations}

The analysis of landscape stability used measurements of physical characteristics for a large sample of basins within the eastern Powder River structural basin to develop geomorphic relations. Similar studies and suggestions for design criteria have been made by hydrologist working with the mine companies and State and Federal agencies. (See for example: articles by Bergstrom (1985), Harvey and others (1985), and Kearney (1985), published in proceedings of the "Second Hydrology Symposium on Surface Coal Mining in the Northern Great Plains"; Knutson (1982), Lidstone (1982), and Tarquin and Baeder (1982), published in proceedings of the "Hydrology Symposium on Surface Coal Mines in the Powder River Basin"; and Divis and Tarquin, 1981. 


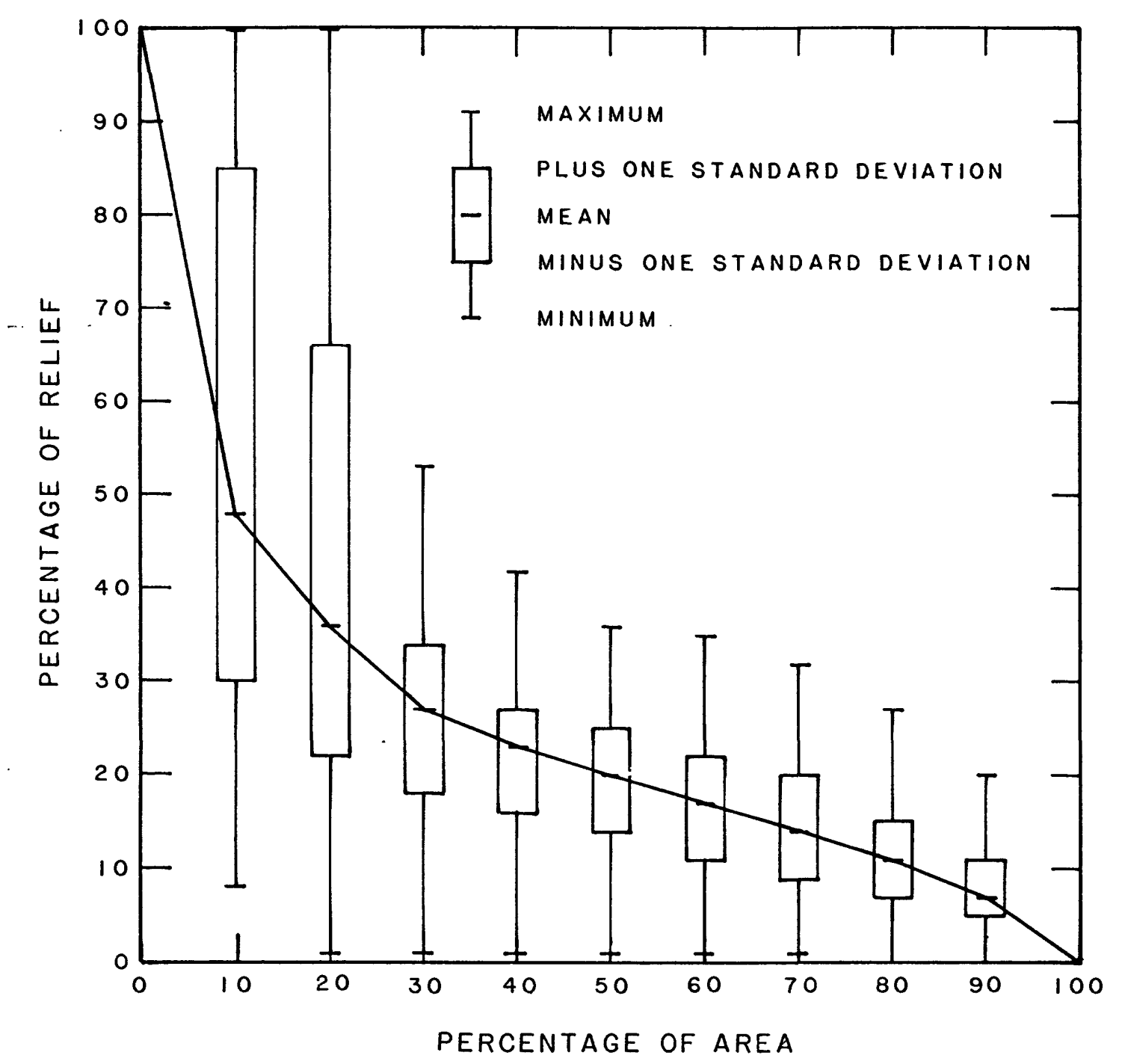

Figure 22.--Average hypsometric curve for secondorder basins (represents 22 basins). 


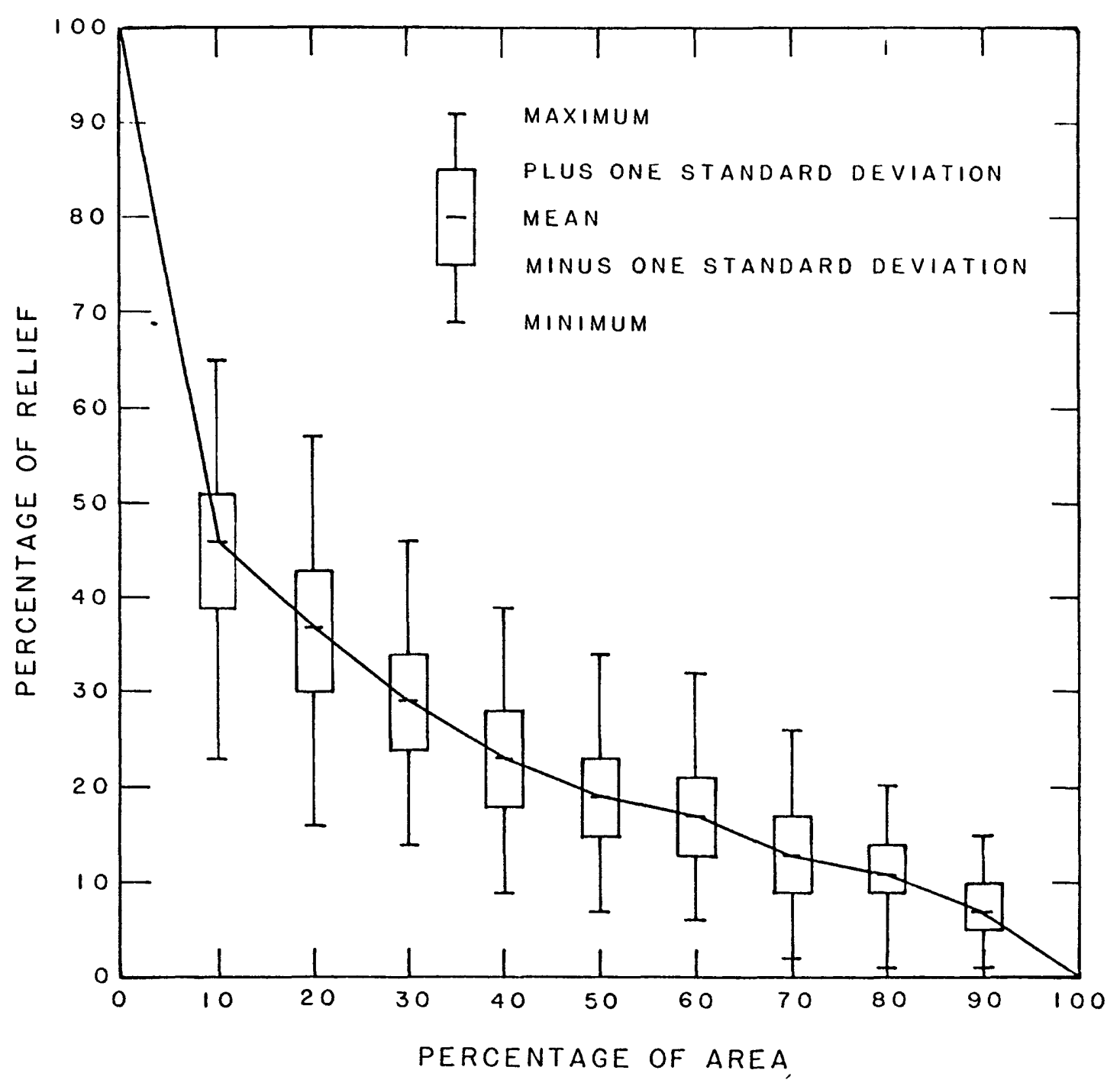

Figure 23.--Average hypsometric curve for thirdorder basins (represents 24 basins). 


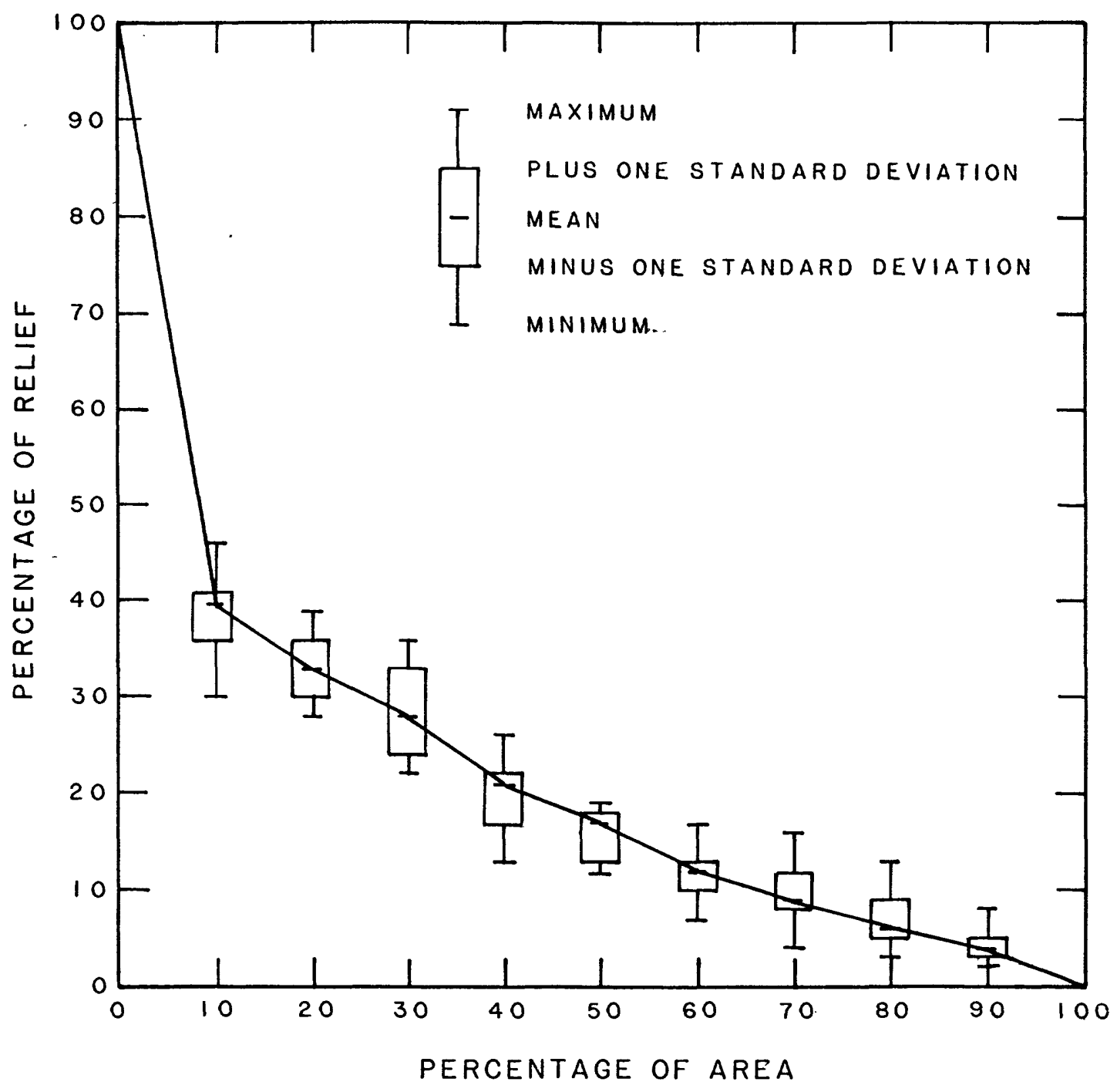

Figure 24.--Average hypsometric curve for fourthorder basins (represents five basins). 
The Wyoming Department of Environmental Quality (1980) has issued recommended guidelines for mining companies to measure physical characteristics for their respective permit areas. The data and relations determined by the companies may vary from those of this study, depending on the scale of maps or aerial photographs used, the number of basins sampled, and the local relief.

The application of geomorphic relations derived from natural or premined basins to the design of postmining basins is based on the assumption that postmining basins will have soil and vegetative cover similar to premined basins. It should be kept in mind that many of the first- and second-order streams for natural basins have relatively steep slopes that are supported by erosion-resistant outcrops. If such outcrops are not present in the postmining drainages, then slopes indicated by the geomorphic relations may be steeper than the reclaimed areas of spoil material can actually support. As mining progresses, documentation of successes and failures in the re-establishment of drainages would be helpful to refinement of design procedures.

\section{Effects of Mining on Landscape Stability}

The determination of the effects of surface coal mining on landscape stability was made by: (1) measuring physical characteristics from postmining plans for a sample of basins and comparing these characteristics to those derived for natural basins, and (2) inspecting drainages onsite that have been reconstructed after mining. Physical characteristics for the sample of planned postmining basins are listed in the following table:

\begin{tabular}{ccccc}
\hline $\begin{array}{c}\text { Drainage area } \\
\text { (square mile) }\end{array}$ & $\begin{array}{c}\text { Channel length } \\
\text { (miles) }\end{array}$ & $\begin{array}{c}\text { Channel order } \\
\text { (obtained from } \\
\text { figure 15) }\end{array}$ & $\begin{array}{c}\text { Used relief } \\
\text { (feet) }\end{array}$ & $\begin{array}{c}\text { Channel slope } \\
\text { (foot per foot) }\end{array}$ \\
\hline 0.88 & 1.15 & 2.2 & 85 & 0.019 \\
.15 & .54 & .8 & 60 & .021 \\
.37 & .73 & 1.4 & 40 & .010 \\
.24 & .46 & 1.1 & 60 & .025 \\
.11 & .41 & .6 & 75 & .035 \\
.077 & .41 & .4 & 55 & .026 \\
.16 & .46 & .8 & 40 & .017 \\
.18 & .49 & 1.0 & 42 & .016 \\
.15 & .61 & .8 & 80 & .025 \\
.35 & .72 & 1.4 & 154 & .058 \\
.78 & 1.85 & 2.0 & 152 & .052 \\
.46 & .92 & 1.6 & 70 & .021 \\
\hline
\end{tabular}

A plot of channel slopes for the sample of postmining basins in comparison to the average relation determined for natural basins is shown in figure 25. Ten of the samples plot near the relation developed for channel slopes of natural basins, but two of the planned channels have slopes greater than the maximum values measured for natural channels. 


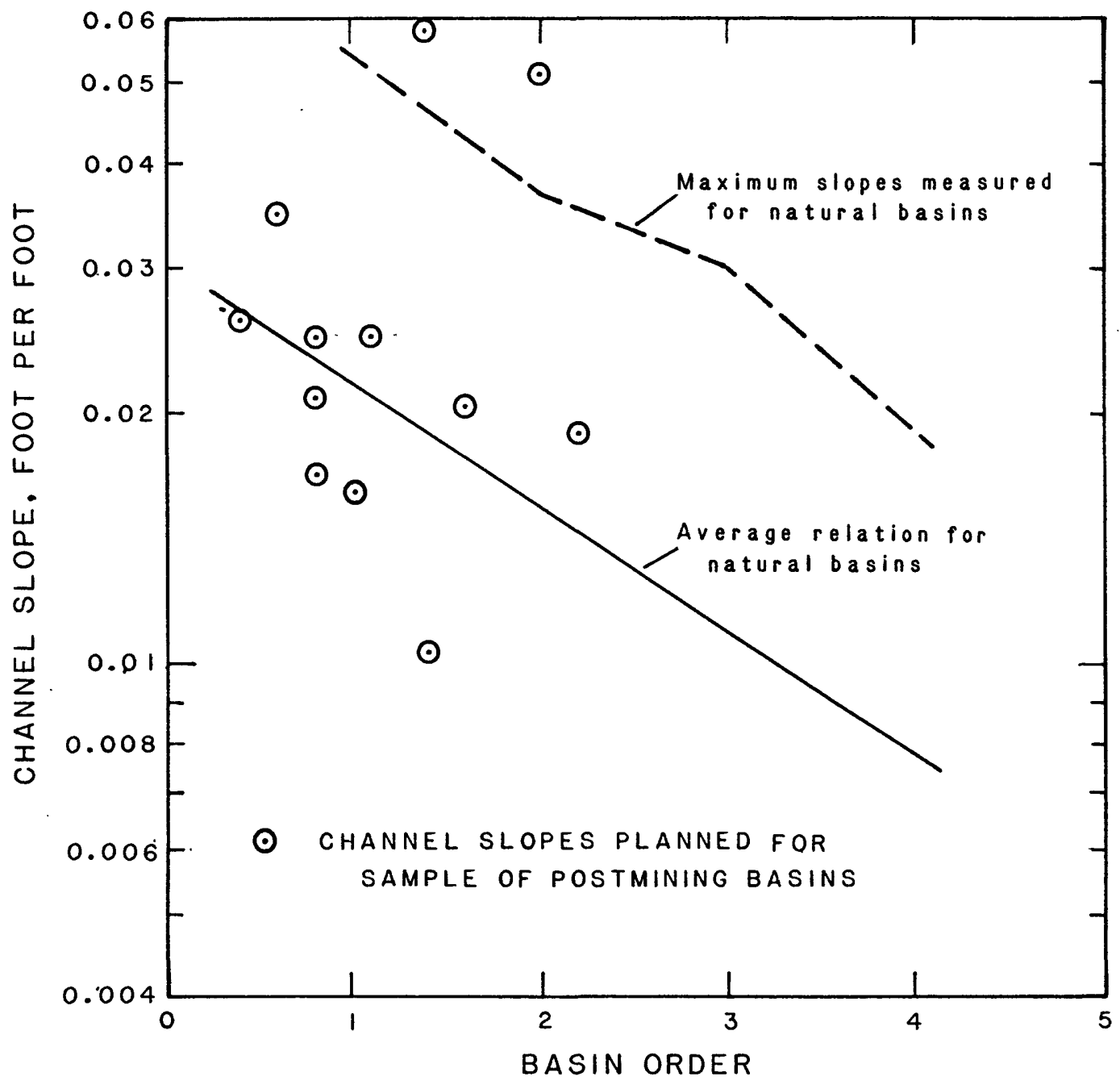

Figure 25.--Comparison of channel slopes for natural and postmining basins. 
The onsite inspection of reconstructed channels indicated results similar to those indicated by the above sample. Many of the reconstructed channels appear to be stable; however a few channels, especially in areas of high relief, are being eroded, which will result in gullying. Streams of Thirdand higher order streams have been given a great deal of attention in design, because they convey relatively large flows than the smaller streams. However, problems are apparent in design of first-and second-order streams in the vicinity of the highwalls. Research is needed in alternative methods for constructing and maintaining stable channels in these areas.

A geomorphic approach can be used as a basis for design of the reconstructed drainage networks. However, in special situations, such as where high relief is present, documented engineering methods are needed to assist with the design of structural controls.

\section{GROUND-WATER SYSTEM}

The ground-water system occurs predominately in a hydrogeologic matrix of lenticular sandstone and siltstone interbedded with shale and coal, which results in discontinuous aquifers limited horizontally and vertically. Ground-water flow can be complex; aquifer properties vary in space and in direction. The Wyodak-Anderson coal bed is the most continuous hydrogeologic unit in the area. However, flow of water in the coal may be affected in places where the coal bed separates to form two or more coal beds with interbedded claystone, shale, or sandstone. Flow in the coal also may be affected by differences in aquifer properties caused by differences in the distribution and density of fracture systeins.

For this study, the principal potential effects of surface coal mining on the ground-water system are assumed to occur in the relatively shallow aquifers. This assumption was made for the following reasons: (1) The depth to which coal will be mined is limited by the overburden-to-coal ratio (the maximum depth of overburden and coal removal presently proposed is $400 \mathrm{ft}$ ), and (2) pumpage from the deep aquifers has not yet affected water levels in the few observation wells currently (1982) monitored and completed in the shallow aquifers, which indicates limited hydraulic connection between the deep and shallow aquifers.

\section{Conceptual Model}

For this report, the shallow aquifer system includes the aquifers in the geologic units overlying the Tullock Nember of the Fort Union Formation: The Lebo Shale and Tongue River Members of the Fort Union Formation, the Wasatch Formation, and the alluvium. In order to simplify study of the complex ground-water system, the shallow aquifer system is divided in descending order into three geohydrologic units (fig. 26): The Wasatch-upper Tongue River aquifer, the Wyodak-Anderson aquifer, and the lower Tongue River-Lebo aquifer. Each unit is assumed to function as a homogeneous aquifer. Aquifer properties for each unit were obtained from data presented in the various mine plans. 


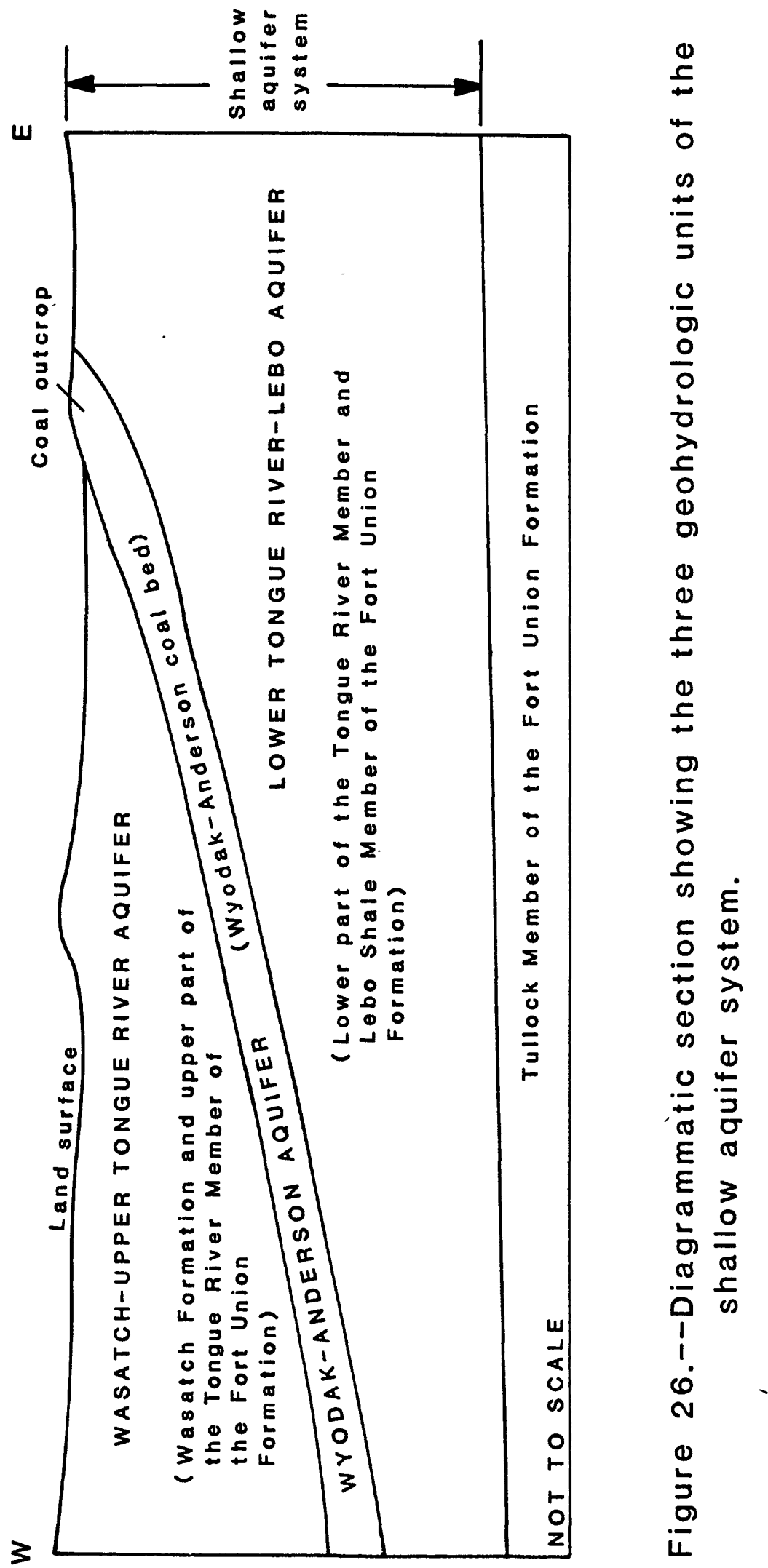


The Wasatch-upper Tongue River aquifer is in the upper part of the Tongue River Member, the Wasatch Formation, and the alluvium. The thickness ranges from 0 at the coal outcrop to about $1,000 \mathrm{ft}$ in western Campbell County. The entire aquifer is assumed to be unconfined with a specific yield ranging from 0.1 to 0.3 . Transmissivity reportedly ranges from about 0.4 to $770 \mathrm{ft}^{2} / \mathrm{d}$.

The Wyodak-Anderson aquifer, comprised of the Wyodak-Anderson coal bed, is in the Tongue River Member. According to G.B. Glass (Lowry, Wilson, and others, in press), the thickness of the coal bed ranges from 25 to $175 \mathrm{ft}$ and probably averages about $70 \mathrm{ft}$. In places, the coal bed separates into two beds, each about 10 to $65 \mathrm{ft}$ thick. Elsewhere, the coal bed may separate into as many as five coal beds, each about 3 to $38 \mathrm{ft}$ thick and separated by a few feet to as much as $200 \mathrm{ft}$ of claystone, shale, and sandstone. Thus, the Wyodak-Anderson aquifer in places may consist of coal interbedded with claystone, shale, and sandstone. Except in the outcrop area, the aquifer is assumed to be confined, with storage coefficients ranging from $1 \times 10^{-6}$ to $1 \times 10^{-4}$. Reported transmissivity values from aquifer tests range from about 0.7 to $10,000 \mathrm{ft}^{2} / \mathrm{d}$. The Wyodak-Anderson aquifer includes clinker or "scoria" beds in some areas. These beds are widespread along the coal outcrop and are the result of past burning of coal beds and baking of rocks in the overlying formations. The scoria varies in texture from dense and glassy to vesicular and porous.

The lower Tongue River-Lebo aquifer is assumed to be in the lower part of the Tongue River Nember and the Lebo Shale Member of the Fort Union Formation. Not all members are mapped at all locations and some consider the Tongue River Member, which contains the Wyodak-Anderson coal bed, to be a facies in the Lebo Shale Member. The Lebo Shale Member directly underlies the coal in the southeastern part of the study area, and the aquifer properties of the Lebo were used to represent the lower Tongue River-Lebo aquifer throughout the study area. The Lebo Shale Member ranges in thickness from 0 to $1,000 \mathrm{ft}$. Except in the outcrop area, it is confined with a storage coefficient of $5 \times 10^{-4}$ to $1 \times 10^{-5}$. Transmissivity ranges from 0.3 to $600 \mathrm{ft}^{2} / \mathrm{d}$. The aquifer properties were obtained from W.R. Hotchkiss (U.S. Geological Survey, written commun., 1983) and from data presented in mine plans.

\section{Ground-Water Flow}

Water flows through a series of discontinuous, lenticular sandstone and fractured coal beds in the shallow aquifer system. The rate and direction of flow primarily is governed by the transmissivity of tine aquifer and the hydraulic gradients in response to the magnitude and location of ground-water recharge and discharge. The general direction of flow in the three aquifers is from the south and southwest to the north under natural, undisturbed conditions.

The approximate water-level contour map for the Wasatch-upper Tongue River aquifer (fig. 27) was constructed by plotting and contouring landsurface altitudes of streambeds for perennial streams and altitudes of water levels in wells completed in the Wasatch Formation, the Fort Union Formation above the coal, and alluvium. The altitudes of streambeds were obtained from land-surface altitudes along streams on U.S. Geological Survey 1:24,000-scale 


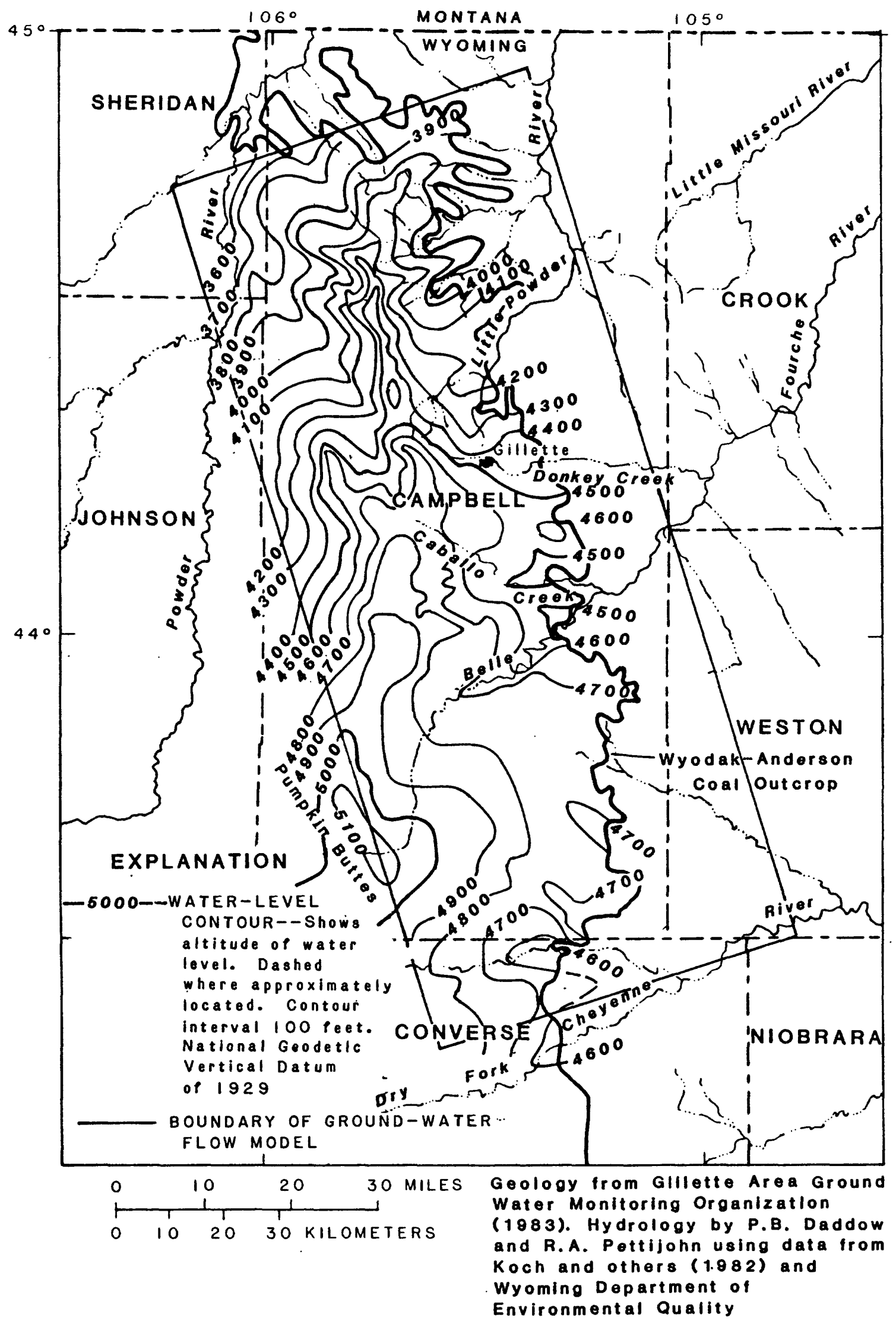

Figure 27.--Approximate water-level contours for the Wasatch-upper Tongue River aquifer. 
topographic maps. The water-level data were from a report by Koch and others (1982). In much of the area, data were not available and contours were located approximately by assuming that the water-level altitudes reflected the topography and that water in the shallow Wasatch-upper Tongue River aquifer flows toward streams. The resulting water-level-contour map was modified for areas of present or planned coal mining using premining data from the Wyoming Department of Environmental Quality mining permits.

As shown in figure 27, flow in the Wasatch-upper Tongue River aquifer is characterized by numerous changes in direction and gradient. Such a configuration probably is a reflection of the quantity and quality of the data used in the construction of the map. The configuration also is typical of aquifers with complex distributions of recharge and discharge as well as variable 1ithology. The general direction of flow appears to be from the south and southwest to the north, with areas of local discharge.

The approximate potentiometric map for the Wyodak-Anderson aquifer (fig. 28) is assumed to represent premining conditions. This is a reasonable assumption except in the area just east of Gillette where mining began in the $1920^{\prime} \mathrm{s}$ and no premining data exists. The map was constructed by plotting and contouring altitudes of water levels in wells completed in the Wyodak-Anderson coal bed of the Tongue River member of the Fort Union Formation. Most of the water-level data in the areas of present or planned coal mining were obtained from the Wyoming Department of Environmental Quality mining permits. Where a large number of wells exist in a local area, representative water-level altitudes are shown in figure 28. The water-level data for wells near the boundaries of the study area were from the files of the U.S. Geological Survey.

The existence of the trough in the potentiometric surface in the far south-central part of the study area is questionable. Because the trough was drawn on the basis of a few data points with questionable accuracy, more accurate data are needed to confirm its existence.

The approximate potentiometric-surface map for the lower Tongue RiverLebo aquifer (fig. 29), as was the case with the maps for the other two aquifers, is assumed to represent premining conditions. Another assumption is that although the potentiometric surface is for the Lebo' Shale, it can be used to represent the entire lower Tongue River-Lebo aquifer. The map was prepared by W.R. Hotchkiss and J.F. Levings and later published with a 200-ft contour interval (Hotchkiss and Levings, 1986). The data available to construct this map were few; therefore, the potentiometric contours are not very reliable, particularly in the western part of the study area.

All data used to construct the water-level contour and potentiometricsurface maps were previously collected and accepted as valid. However, there were some known problems associated with the use of the data. The groundwater-level data were collected during many years. Few data on an areal basis were available for any one time period. Also, contours may be in error by as much as 50 to $100 \mathrm{ft}$ in areas where land-surface altitude of wells were determined from topographic maps with $100-\mathrm{ft}$ contour intervals, and well locations were known only to the nearest $0.25 \mathrm{mi}$. 


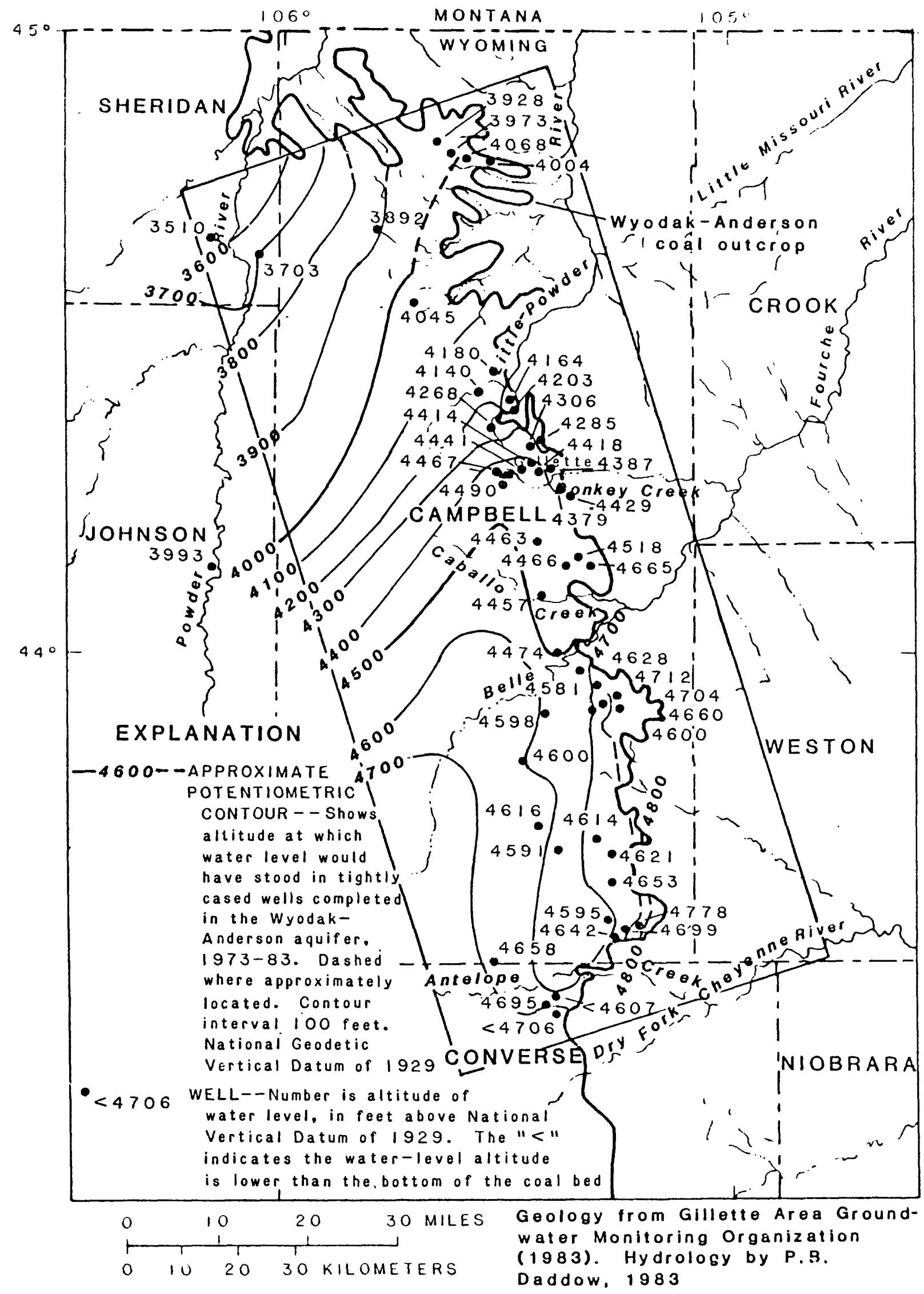

Figure 28.--Approximate potentiometric surface of the Wyodak-Anderson aquifer, 1973-83. 


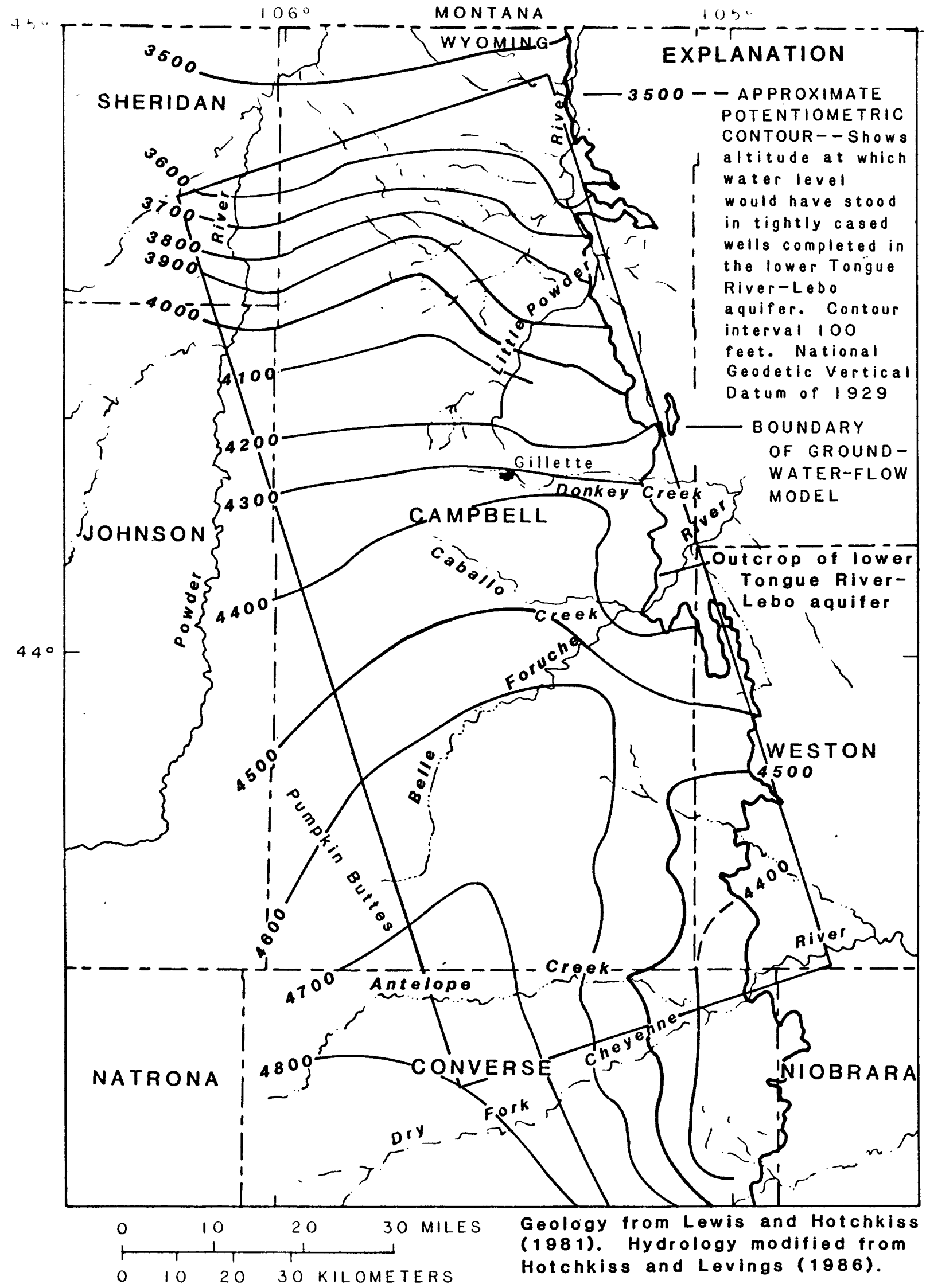

Figure 29.--Approximate potentiometric surface of the lower Tongue River-Lebo aquifer, 1975-80. 


\section{Recharge and Discharge}

Recharge to the Wasatch-upper Tongue River aquifer is from infiltration of precipitation and streamflow. Principal recharge to the Wyodak-Anderson aquifer is infiltration of precipitation in the outcrop area. The most significant recharge probably occurs in the areas of exposed clinker, where recharge may be an order of magnitude greater than elsewhere.

Discharge from the shallow aquifer system occurs primarily by underflow out of the study area and discharge to perennial streams. Underflow out of the study area occurs to the north and northwest in all three geohydrologic units. Some underflow also occurs to the east from the lower Tongue RiverLebo aquifer in the southeastern part of the study area. No direct measurement of underflow is possible, even though underflow probably represents the major component of discharge from the study area.

Discharge from the aquifer system to streams is not well defined. The only perennial streams in the study area are the Belle Fourche and Little Powder Rivers (fig. 2). Seepage runs made during low-flow in 1978 (Druse and others, 1981) indicate that the Belle Fourche gains about $2.4 \mathrm{ft}^{3} / \mathrm{s}$ and the Little Powder River gains about $2.0 \mathrm{ft}^{3} / \mathrm{s}$ along their perennial reaches within the study area. These measurements were made during an unusally wet year and may overestimate long-term steady-state conditions.

Evapotranspiration, discharge to springs, and pumping for stock and domestic use are considered minor sources of discharge from the ground-water system. Depths to water generally are below the depth at which any major evaporation or transpiration occurs. Many stock and domestic wells are located throughout the study area. Pumping from any one of these wells usually is of short duration and at a slow rate and, thus, would have little effect on water levels in the system.

\section{Uncalibrated Computer Model}

In order to predict the effects of surface coal mining on the groundwater system in the study area, an attempt was made to'mathematically simulate ground-water flow. The quasi-three-dimensional, finite-difference, groundwater-flow model described by Trescott (1975) and Trescott and Larson (1976) was used to represent the conceptualized ground-water flow in the shallow aquifer system. In the finite-difference formulation of the ground-water-flow equation, a geohydrologic unit can be conveniently represented in the model by one layer of nodes. This approach was used to represent the shallow aquifer system in part of the Powder River structural basin.

Although the computer model was not successfully calibrated, the modeling effort is briefly documented in order to illustrate the problems of modeling the complex aquifer system in the Powder River structural basin. The documentation includes a brief description of the simplifying assumptions, boundary conditions, variable grid, and initial hydrologic data required for calibration. 
Because the aquifer system in the study area is complicated beyond our capacity to describe it, the system cannot be treated exactly as it exists. The conceptual model used in this study is a simplification of the complex physical system. The following assumptions were made in order to simplify the physical system for modeling:

1. All perennial streams are discharge points.

2. All water-level measurements used for contouring water-level surfaces represent premining conditions and are in a state of equilibrium.

3. Aquifer characteristics are average values for the nodal area.

4. Hydraulic conductivity of the Wasatch-upper Tongue River and the Wyodak-Anderson aquifers is uniform in value in each layer.

5. Specific yield of the Wasatch-upper Tongue River aquifer and the storage coefficient of the Wyodak-Anderson and lower Tongue RiverLebo aquifers are uniform in each layer.

6. Discharge from the aquifer system by evapotranspiration, springs, and pumping from stock and domestic wells is negligible.

7. Recharge from precipitation is uniformly distributed over the modeled area, except for exposed areas of clinker.

8. Vertical rate of ground-water flow in the aquifer system is not known; thus, an initial estimate is used and subsequently would have been adjusted during model simulation.

\section{Boundaries and Variable Grid}

The boundaries of the modeled area extend about $10 \mathrm{mi}$ east of the coal outcrop and about $30 \mathrm{mi}$ west of the area between Buckskin and Coal Creek Mines where mining was to be simulated by the model (fig. 30). The north and south boundaries extend $20 \mathrm{mi}$ beyond the mined area to be simulated. The total area of the model is about 4,400 $\mathrm{mi}^{2}$.

Constant-head and no-flow boundaries were used in the model. The Wasatchupper Tongue River and Wyodak-Anderson aquifers were simulated with constanthead boundaries along the west, south, and north sides. The eastern edge of the outcrops of the two aquifers were simulated as no-flow boundaries. The lower Tongue River-Lebo aquifer was simulated with constant-head boundaries on all four sides of the model. The base of the Lebo Shale Member of the Fort Union Formation, the lower boundary of the lower Tongue River-Lebo aquifer, was considered to be an impermeable boundary for the aquifer system.

The variable grid used in the model, which has 32 rows and 123 columns (fig. 30), has variable nodal spacing ranging from 0.5 to $5.7 \mathrm{mi}$. The smallest nodal spacing is in the area where mining was to be simulated. The nodal spacing increases by 1.5 times from node to node from the simulated mining area outward to the model boundaries. The Wasatch-upper Tongue River aquifer is simulated from its eastern model boundary to the western boundary of the grid system. The Wyodak-Anderson aquifer is simulated from its eastern model boundary to the western boundary of the grid system. The lower Tongue RiverLebo aquifer is simulated throughout the area modeled. 


\section{Hydrologic Data}

The hydrologic data used in the steady-state calibration of the model of the conceptualized shallow aquifer system included the following: altitudes of water-levels and hydraulic head; saturated thickness; horizontal hydraulic conductivity and transmissivity; specific yield and storage coefficient; and vertical hydraulic conductivity. Estimates were made of pumpage from the mines. Hydrologic data were determined for each node in the variable grid for the model area. The data values are assumed to be the average value for the cell area assigned to each node.

The initial estimates for all data arrays needed for the threedimensional model were obtained either by laying the grid system over maps of the contoured data to select a value for each of the nodes, or by placing a uniform value into the data array during simulation. The arrays obtained by laying the grid over maps of the data were the water-level surfaces for the three units (figs. 27-29): the altitude of the top of the coal (fig. 31), the thickness of the coal (not illustrated), and the transmissivity of the lower Tongue River-Lebo aquifer (fig. 32). The data arrays of uniform values were as follows:
1. Hydraulic conductivity of the Wasatch-upper Tongue River aquifer, $0.67 \mathrm{ft} / \mathrm{d}$.
2. Hydraulic conductivity of the Wyodak-Anderson aquifer, $1.34 \mathrm{ft} / \mathrm{d}$.
3. Specific yield of Wasatch-upper Tongue River aquifer, 0.10 .
4. Storage coefficient of the Wyodak-Anderson aquifer, $2 \times 10^{-5}$.
5. Storage coefficient of the lower Tongue River-Lebo aquifer, $2 \times 10^{-4}$.
6. Recharge from precipitation, 0.2 in/yr (an average of $75 \mathrm{ft}^{3} / \mathrm{s}$ in the study area) (M.E. Lowry, U.S. Geological Survey, written commun., 1983).

The data used to construct the map showing the thickness, altitude, and configuration of the Wyodak-Anderson coal bed ( $f i g .31$ ) were obtained from the Branch of Coal Resources (U.S. Geological Survey, written commun., 1983), computerized data base of drillhole-log data. The saturated thickness of the Wasatch-upper Tongue River was computed as the difference between the altitude of the water-level surface (from the water-level-contour map) and the altitude of the top of the coal.

Transmissivity and storage-coefficient data and methods of analysis used to determine the data values were tabulated from the mining permits on file with the Wyoming Department of Environmental Quality. The thickness of aquifer was rarely given with the transmissivity data. Hydraulic-conductivity and storage-coefficient or specific-yield data were obtained from Rehm and others (1980), and U.S. Department of the Interior (1979).

Horizontal hydraulic conductivity for sands in the aquifers is estimated to be $1.5 \mathrm{ft} / \mathrm{d}$ for the Wasatch-upper Tongue River aquifer and $1.0 \mathrm{ft} / \mathrm{d}$ for the lower Tongue River-Lebo aquifer. The estimates are based on the average of values obtained from aquifer tests in wells completed in sandstone in Campbell County, Wyoming (U.S. Department of the Interior, 1979, table PB-2). The aquifer-test data were adjusted on the basis of estimates of the percentage of sandstone in units overlying the Lebo Shale Member of the Fort Union Formation (Lewis and Hotchkiss, 1981, pl. 1). 


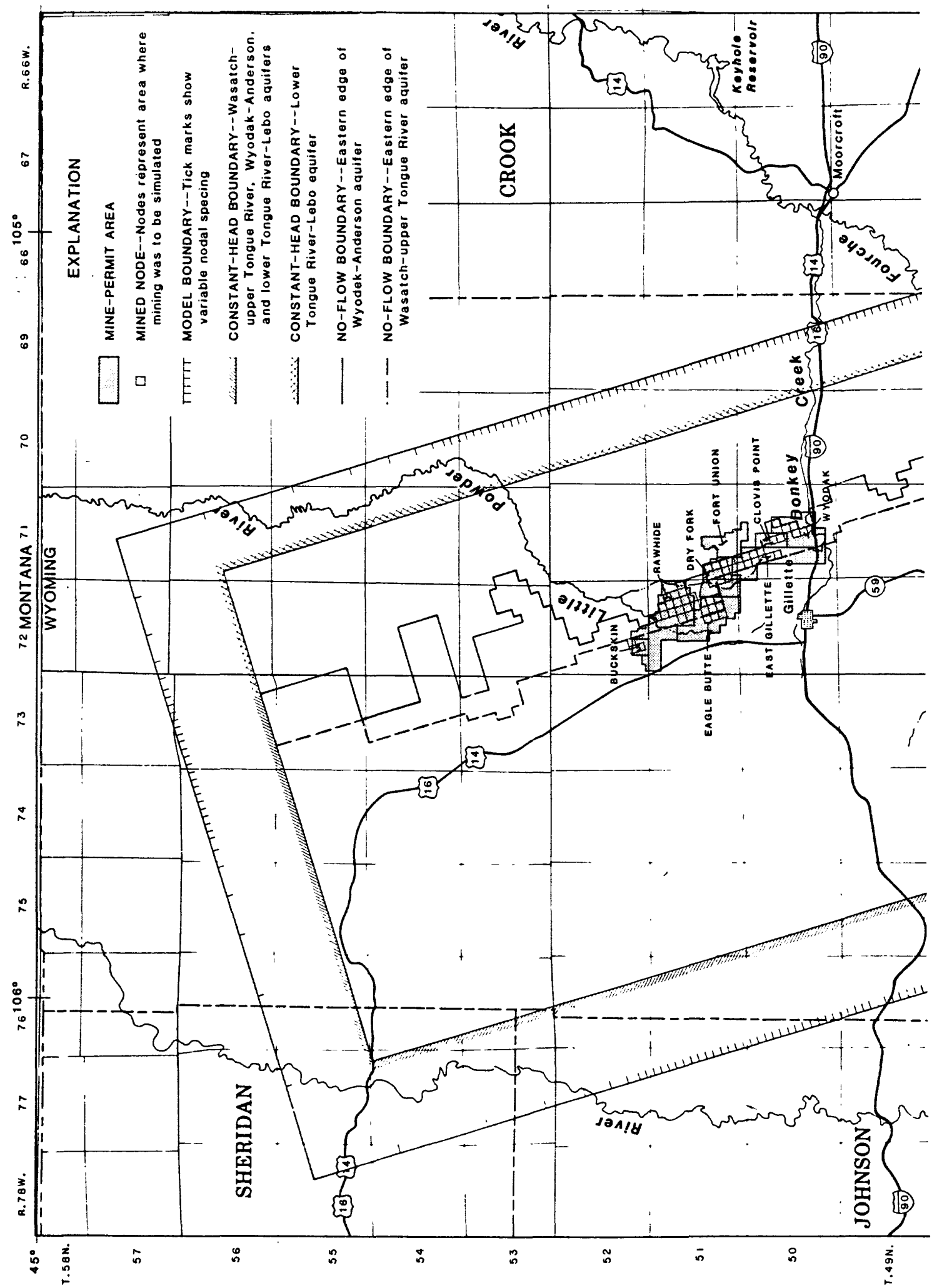




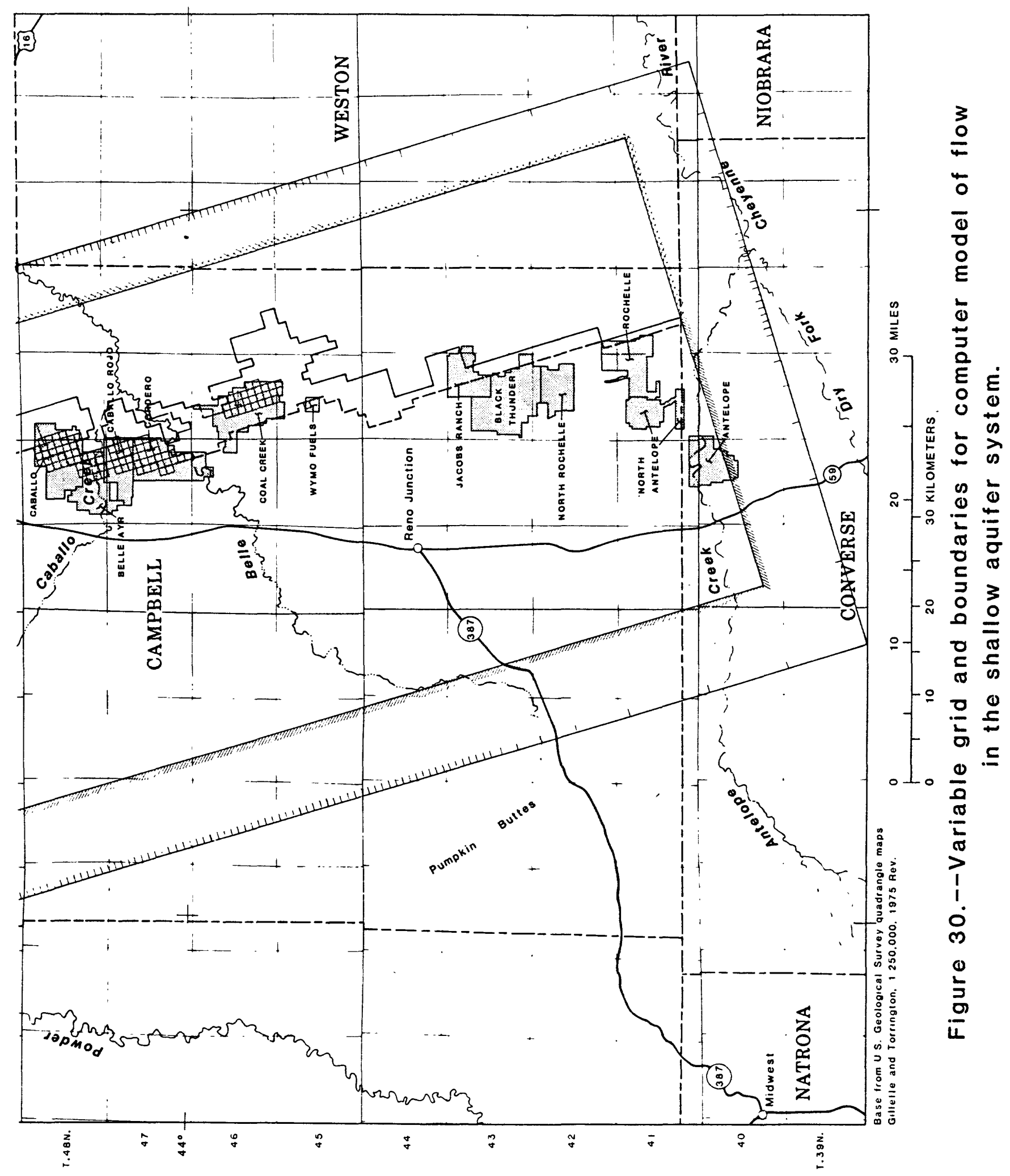




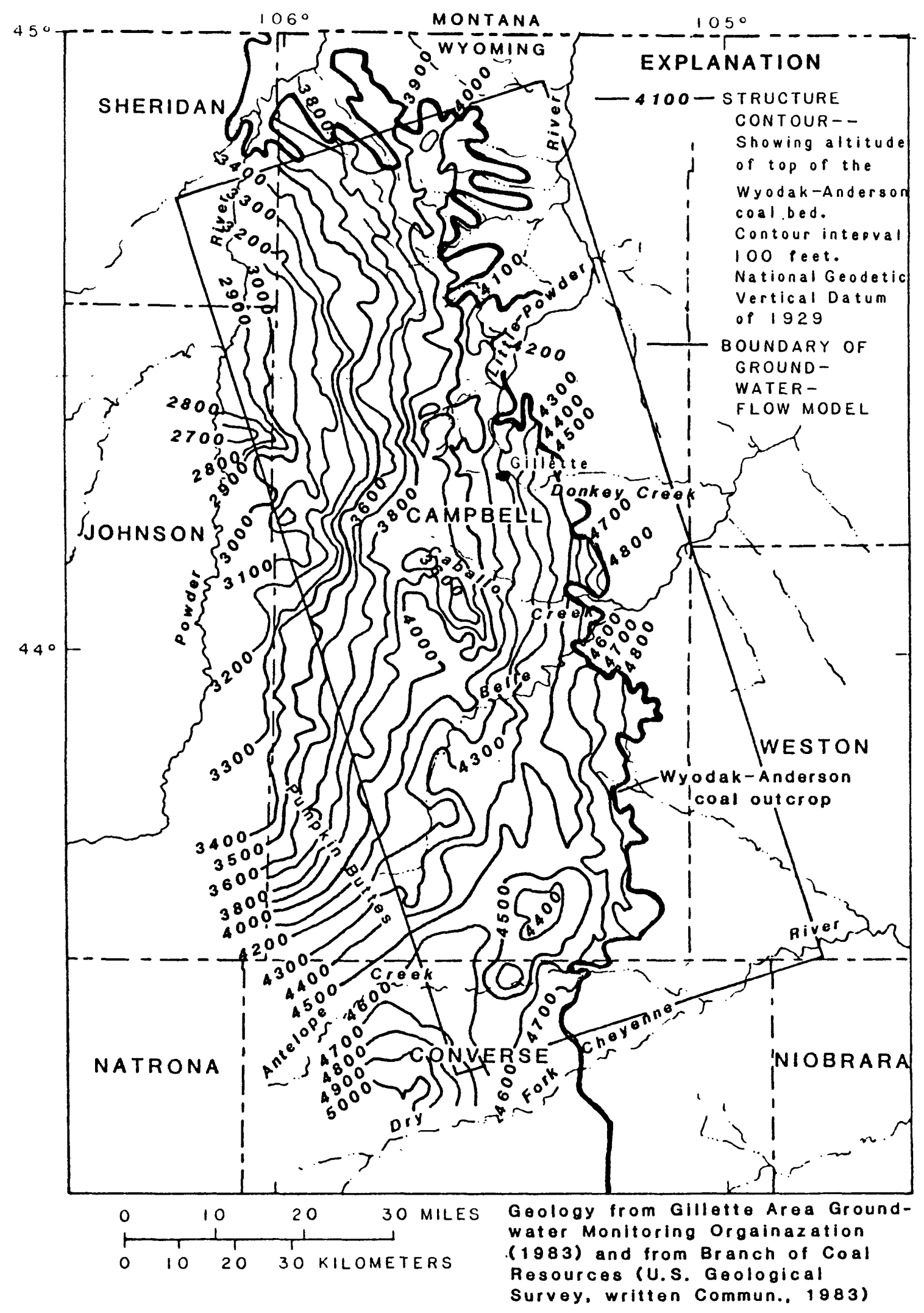

Figure 31.--Altitude and configuration of the top of the Wyodak-Anderson coal bed. 
Horizontal hydraulic conductivity of the Wyodak-Anderson coal bed is estimated to be $5 \mathrm{ft} / \mathrm{d}$. The estimate is on the basis of data reported by the U.S. Department of the Interior (1979, table RP-2).

The transmissivity of the lower Tongue River-Lebo aquifer was obtained from W.R. Hotchkiss (U.S. Geological Survey, written commun., 1983). The transmissivity distribution was developed by Hotchkiss using a geostatistical technique known as kriging. This technique takes advantage of the spatialcorrelation structure of the data to estimate transmissivity where no data are available. One useful outcome of the kriging technique is the ability to calculate a standard error for the transmissivity estimates. If the standard error is small when compared to the estimate, the transmissivity distribution can be considered as well known. In general, the standard error for estimated transmissivity of the lower Tongue River-Lebo aquifer is less than one-half the transmissivity values.

Specific yield of the Wasatch-upper Tongue River aquifer is estimated to be 0.001 . Estimates of specific yield reported by the U.S. Department of the Interior (1979, table RB-2) were increased slightly to consider the effects of long-term drainage that would not occur during normal aquifer tests.

Specific storage is estimated to be 0.00001 for the Wyodak-Anderson aquifer and 0.000001 for the lower Tongue River-Lebo aquifer. These two values were accepted as valid even though a case could be made for a larger specificstorage value for the lower Tongue River-Lebo aquifer rather than the WyodakAnderson aquifer. The specific storage of the Wyodak-Anderson aquifer is the average of values for coal in Campbell County, Wyoming, as presented by the U.S. Department of the Interior (1979, table RB-2). One value in the table was not used in the averaging process. The value discarded was the only one that indicated water table rather than confined conditions existing in the aquifer. The specific-storage value for the lower Tongue River-Lebo aquifer is the average obtained from aquifer tests in wells completed in sandstone in the Fort Union and Wasatch Formations in Campbell County, Wyoming, as presented by the U.S. Department of the Interior (1979, table RB-2).

\section{Documentation of Calibration Problems}

The shallow aquifer system is assumed to be in equilibrium prior to coal mining; that is, natural recharge equals natural discharge, and little variation in water levels is observed for long periods, except for seasonal variations. An aquifer so described is said to be in a steady-state condition.

The data previously described were used in the model to simulate the shallow aquifer system at steady-state conditions. Storage-coefficient values, specific-yield values, and discharge data from dewatering of the aquifer were not needed in the steady-state model. As stated earlier, the only recharge to the aquifer system during steady-state conditions is $0.2 \mathrm{in} / \mathrm{yr}$ from precipitation. Underflow into or out of the area modeled and discharge to perennial streams was simulated using constant-head nodes. 
Direct measurement of all aquifer properties needed to construct a model of ground-water flow rarely is possible. When available, measurements usually contain some error and, in the case of properties such as hydraulic conductivity, reflect conditions at a point rather than regional values. To overcome these problems, hydrologist are forced to estimate aquifer properties within the context of digital models while treating recharge, discharge, and hydraulic head as known regional values. Both formal statistical methods and trialand-error approaches have been used to solve this inverse problem. This process of obtaining a set of mutually consistent aquifer properties is called calibration. Methods also exist for calibrating flow models when recharge, discharge, and hydraulic head are not precisely known (Cooley, 1982), but as the uncertainty in these aquifer properties increases, the estimation error of the model also increases. An extreme can be reached when no reliable estimates of aquifer properties or of recharge-discharge relations are available prior to model calibration. In such a case, a reasonable model calibration rarely is possible.

As indicated previously, the data required for a flow model of the shallow aquifer system are associated with various degrees of error. Values for some aquifer properties, such as the thickness and areal extent of the geohydrologic units, are well established. Other aquifer properties, such as transmissivity of the lower Tongue River-Lebo aquifer and the water-level surface of the Wasatch-upper Tongue River aquifer, are not as well defined. Virtually no data are available for some aquifer properties, such as the vertical hydraulic conductivity. It was recognized at the beginning of this study that the uncertainty associated with the various aquifer characteristics would preclude extensive or precise model calibration.

Although accurate calibration was initially recognized as not possible, an attempt at calibration was made. In attempting calibration, the magnitude of aquifer properties was estimated and effects of planned mining were predicted. The changes in aquifer properties and the results of these predictions are presented later.

Data adjustments were made in the attempt to calibrate the model. The water-level surface of the Wasatch-upper Tongue River aquifer was smoothed in the direction of flow in an attempt to avoid large oscillations in the iterative technique used to solve the flow problems; however, large oscillations occurred, and the solution could not be made to converge. In addition, the water-level surface of a unit was smoothed whenever a hydraulic-head value in a node was substantially different from hydraulic-head values in horizontal adjoining nodes and was not explainable from available information.

The hydraulic conductivity of the Wasatch-upper Tongue River aquifer and the Wyodak-Anderson aquifer, and the transmissivity of the lower Tongue RiverLebo aquifer were adjusted. The adjustments were limited to about one order of magnitude from the initial estimates previously given.

The vertical hydraulic conductivity was adjusted to obtain the best fit of calculated to measured potentiometric-surface data. The rate of flow between layers is controlled by the vertical components of hydraulic conductivity of the adjacent layers and was entered in the model as two values, one for vertical conductivity between the Wasatch-upper Tongue River and WyodakAnderson aquifers and another for vertical conductivity between the WyodakAnderson and lower Tongue River-Lebo Aquifers. 
Problems also were encountered with the Wasatch-upper Tongue River aquifer becoming dewatered during the simulations. Because clinker deposits are very permeable, and where exposed at the surface should accept a larger recharge than adjacent deposits, recharge was increased from 0.2 to $4.0 \mathrm{in} / \mathrm{yr}$ where clinker is exposed, in an effort to keep the aquifer saturated. However, this did not work. Ground-water-level declines computed by the model continued to be greater than the saturated thickness of the aquifer. When such a situation occurs, no solution is possible. In a trial-and-error attempt to adjust parameters and keep the Wasatch-upper Tongue River aquifer saturated, 14 different steady-state simulations were run unsuccessfully.

The limited time available to collect and assemble data, to process the data into the-format needed for computer entry, and to apply the model was a severe constraint on model calibration: Furthermore, the quality of some of the data were known to be questionable, even though all data were accepted as valid without evaluation.

Knowledge of ground-water flow in the eastern part of the study area, or more specifically in the coal outcrop area, is most questionable. The coal outcrop is the most hydrologically complicated area, so some problems were expected. Substantially more ground-water recharge may occur in the outcrop area than was originally anticipated, although the Wasatch-upper Tongue River aquifer appears to be dry some distance west of the coal outcrop. An inventory of wells in the area is needed for more water-level information, especially between the mine areas. More precise values for the altitude of the top and bottom of the coal aquifer also are needed. A plan to improve calibration of the model, by obtaining additional data and re-evaluating existing data, is presented later.

\section{Discussion of Unsuccessful Model}

Attempts to model the shallow ground-water system in the study area were unsuccessful. Neither, "steady-state" ground-water levels nor water-level changes resulting from coal-mining activities could be simulated. Disparities between model simulated water-level changes and documented historic changes were as great as $100 \mathrm{ft}$. Koch and others (1982) experienced similar results in an attempt to model the ground-water system in the Powder River structural basin.

The modeling effort failed principally because of insufficient quantity and quality of data to define the aquifer system. For example, data to define the spatial distribution of aquifer properties is limited; data to define ground-water recharge and discharge is incomplete, especially for steady-state conditions; and data to define the hydraulic-head distribution within and between aquifers is questionable.

The principal formations associated with the coal beds of the Powder River basin in Wyoming are the Wasatch and Fort Union. In this study, the formations were divided into three geohydrologic units on the basis of overall lithology. Both formations are characterized by variable lithology, both horizontally and vertically. Although lithofacies can be mapped accurately in outcrops and mine cuts, extension of the lithofacies to the subsurface has not been possible even with extensive drilling programs. Coal beds represent the only laterally continuous beds in the geologic section. 
Flow of water within the Wasatch and Fort Union Formations is three dimensional and reflects the large topographic relief and complex lithologic structure of the basin. Flow can be classified qualitatively on the basis of local, intermediate, and regional scales in keeping with the approach of Freeze and Witherspoon (1967). The quantity of water flowing within the regional system probably is small compared to the quantity of water discharging from local systems. The location of local or intermediate-scale discharge probably is controlled by both topography and the location of permeable lithofacies. Past attempts to model ground-water flow of the basin, as well as the model analysis attempted in this study, have not distinguished successfully between local and regional flow components of the system. Without such knowledge, calibration of flow models has been poor to impossible.

One of the principal reasons data to define the hydraulic-head distribution within and between aquifers is questionable is because in many cases wells in which water levels are measured are not accurately located. The well location, usually known only to the nearest $0.25 \mathrm{mi}$, is plotted on a topographic map. By extrapolating between land-surface contours shown on the topographic map, the land-surface altitude of the well site is determined. Some topographic maps for the study area have 100-ft contour intervals. Finally, the altitude of the water table or potentiometric surface is the land-surface altitude minus the reported depth to water in the well. Given that the well location may be known only to the nearest $0.25 \mathrm{mi}$ and that the contour interval on the topographic map may be $100 \mathrm{ft}$, the error in estimated water level or potentiometric surface may be 50 to $100 \mathrm{ft}$ or more. This assumes that the reported depth to water is correct, which is not always a valid assumption. Additional onsite location of wells, together with waterlevel measurements, are needed to produce accurate water-level maps.

\section{Premining and Postmining Ground-Water Quality}

Available ground-water-quality data were analyzed to determine areal variations in selected water-quality characteristics and constituents for premining and postmining conditions. The Wyoming Department of Environmental Quality mining permits contain large quantities of water-quality data for wells completed in the overburden and coal and limited data for wells completed in spoil. The data represent premining, during-mining, and, at several mines which have been in operation for some time, postmining conditions. Data-quality evaluations such as review for consistency and ionic balance were not made.

The most significant problem in establishing premining water-quality values in the study area is the variability of water quality within the Wyodak-Anderson aquifer (this is also true for the Wasatch-upper Tongue River aquifer). Even within a single permit area, water-quality values in the Wyodak-Anderson aquifer can vary by a factor of 10 or more. For example, in the Eagle Butte permit area (permit areas identified in figure 30), dissolvedsolids concentrations ranged from 543 to $3,625 \mathrm{mg} / \mathrm{L}$ (milligrams per liter), and sulfate concentrations ranged from 1.0 to $2,130 \mathrm{mg} / \mathrm{L}$. 
The water-quality data are presented as listed in the permits, although in a few cases, the average of several analyses for a single well was calculated where no premining average was available. The premining concentrations for dissolved solids, values of $\mathrm{pH}$, and concentrations of sulfate, manganese, boron, and nitrate plus nitrite (as nitrogen) are presented in figures 32-37. The Wyoming Department of Environmental Quality requested that these chemical data be included in this study.

The postmining data presented in figures $32-37$ are from the most recent (1985) analysis available from the Wyoming Department of Environmental Quality mine permits. Postmining data are limited because only five mines have 1985 data for saturated spoil. Some changes from premining values are evident, but the significance is unclear because of the difficulties in determining the representative premining water quality for a permit area.

The premining concentrations of dissolved solids in ground water in the coal aquifer (fig. 32) ranged from 600 to $3,934 \mathrm{mg} / \mathrm{L}$; the postmining concentrations ranged from 1,560 to $6,483 \mathrm{mg} / \mathrm{L}$. Concentrations increased in all four permit areas where both premining and postmining data are available. The premining $\mathrm{pH}$ values in figure 33 ranged from 7.2 to 7.9 and the postmining values from-6.5 to 7.5, with values at three out of four permit areas decreasing from premining to postmining. Both premining and postmining sulfate concentrations are variable (fig. 34); premining concentrations ranged from 4.9 to $2,140 \mathrm{mg} / \mathrm{L}$; postmining concentrations ranged from 524 to $2,960 \mathrm{mg} / \mathrm{L}$. Manganese concentrations increased substantially in most permit areas (fig. 35); premining concentrations ranged from 0.04 to $0.26 \mathrm{mg} / \mathrm{L}$ and postmining concentrations ranged from 0.16 to $5.84 \mathrm{mg} / \mathrm{L}$. Premining concentrations of boron (fig. 36) ranged from 0.03 to $0.68 \mathrm{mg} / \mathrm{L}$; postmining concentrations ranged from 0.04 to $0.45 \mathrm{mg} / \mathrm{L}$. Premining nitrate plus nitrite concentrations (fig. 37) ranged from 0.06 to $116 \mathrm{mg} / \mathrm{L}$; postmining concentrations ranged from 0.04 to $239 \mathrm{mg} / \mathrm{L}$. 


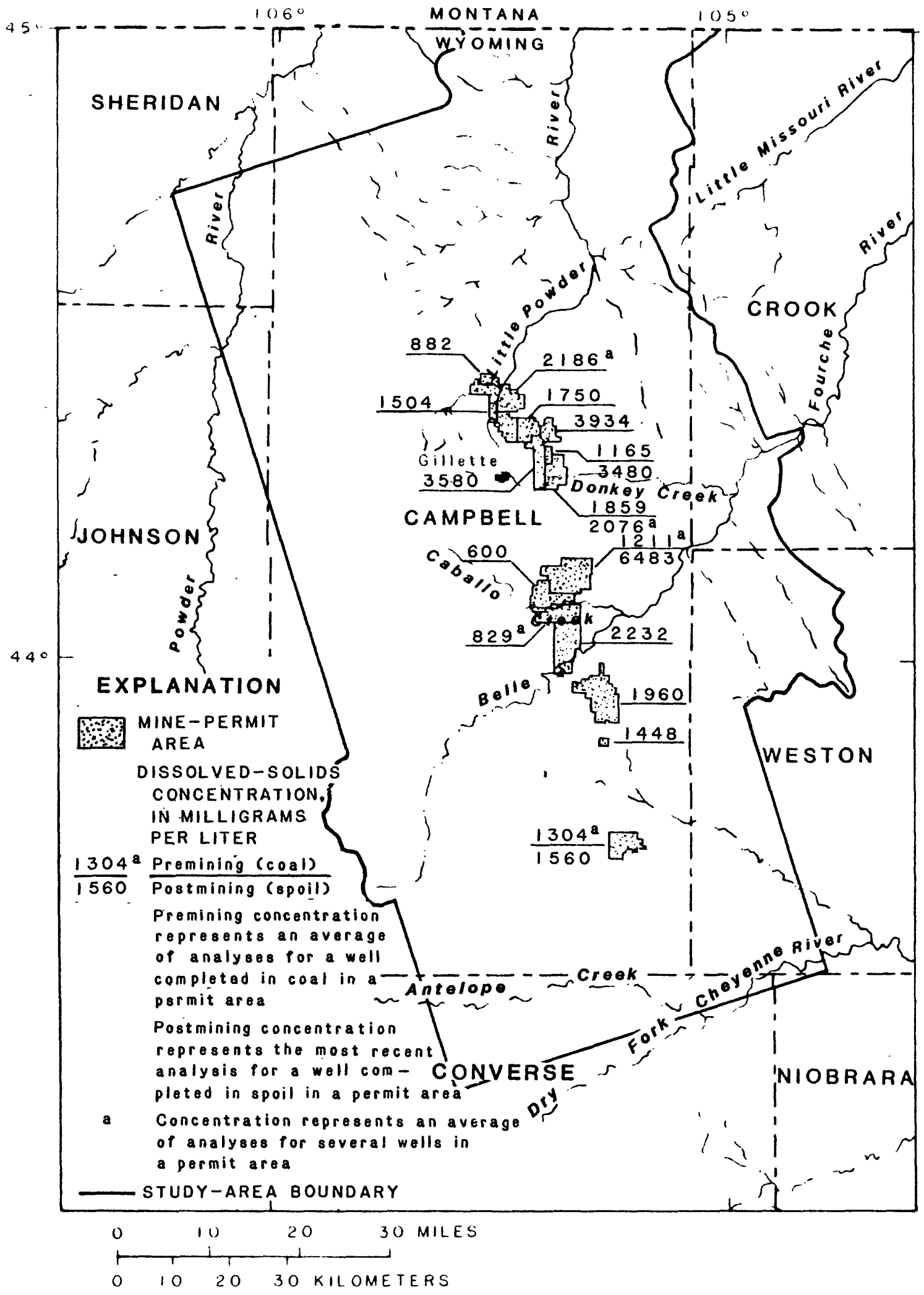

Figure 32.--Premining and postmining concentrations of dissolved solids in ground water. 


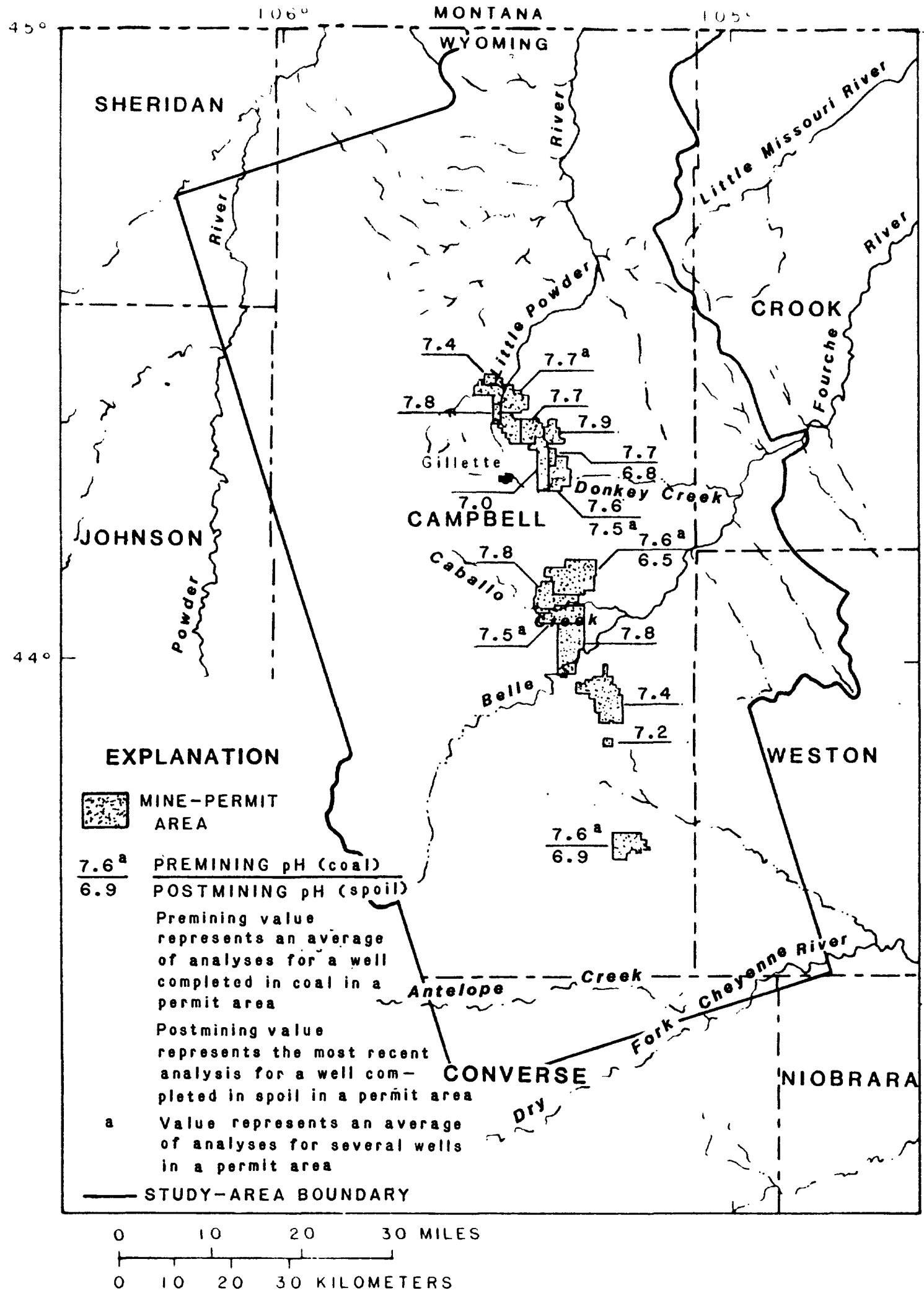

Figure 33.--Premining and postmining values of $\mathrm{pH}$ (laboratory values) in groúnd water. 


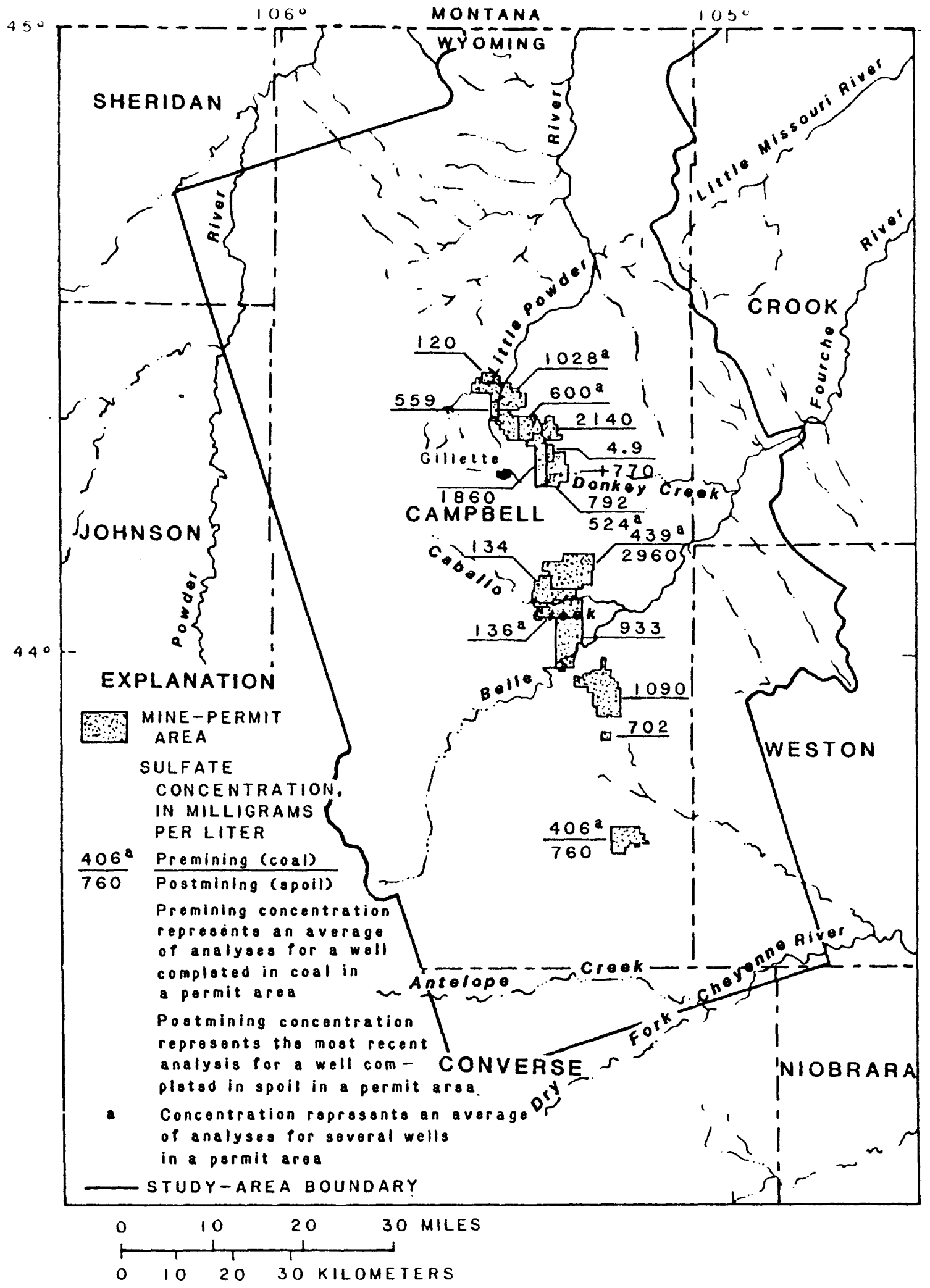

Figure 34.--Premining and postmining concentrations of sulfate in ground water. 


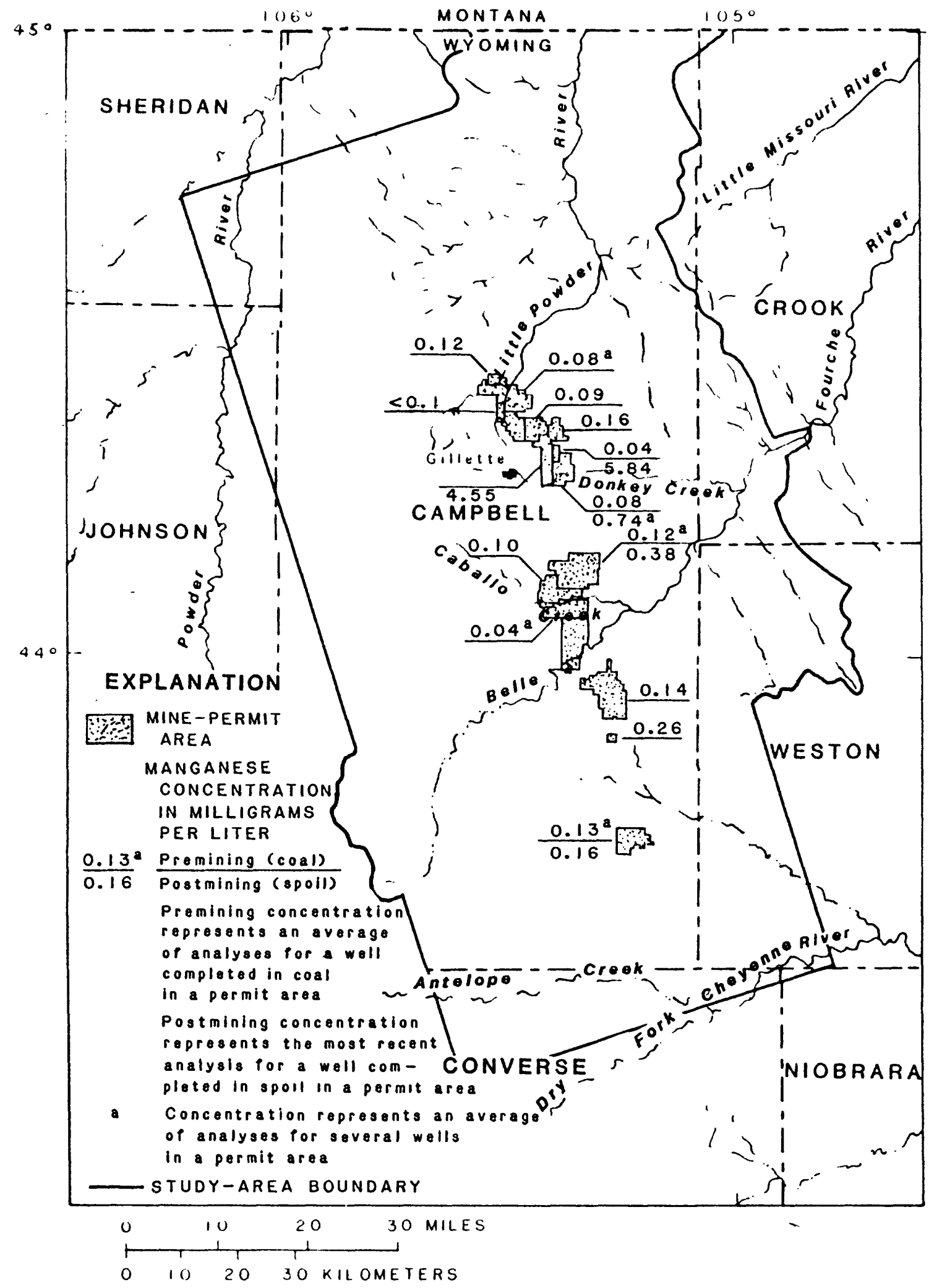

Figure 35.--Premining and postmining concentrations of manganese in ground water. 


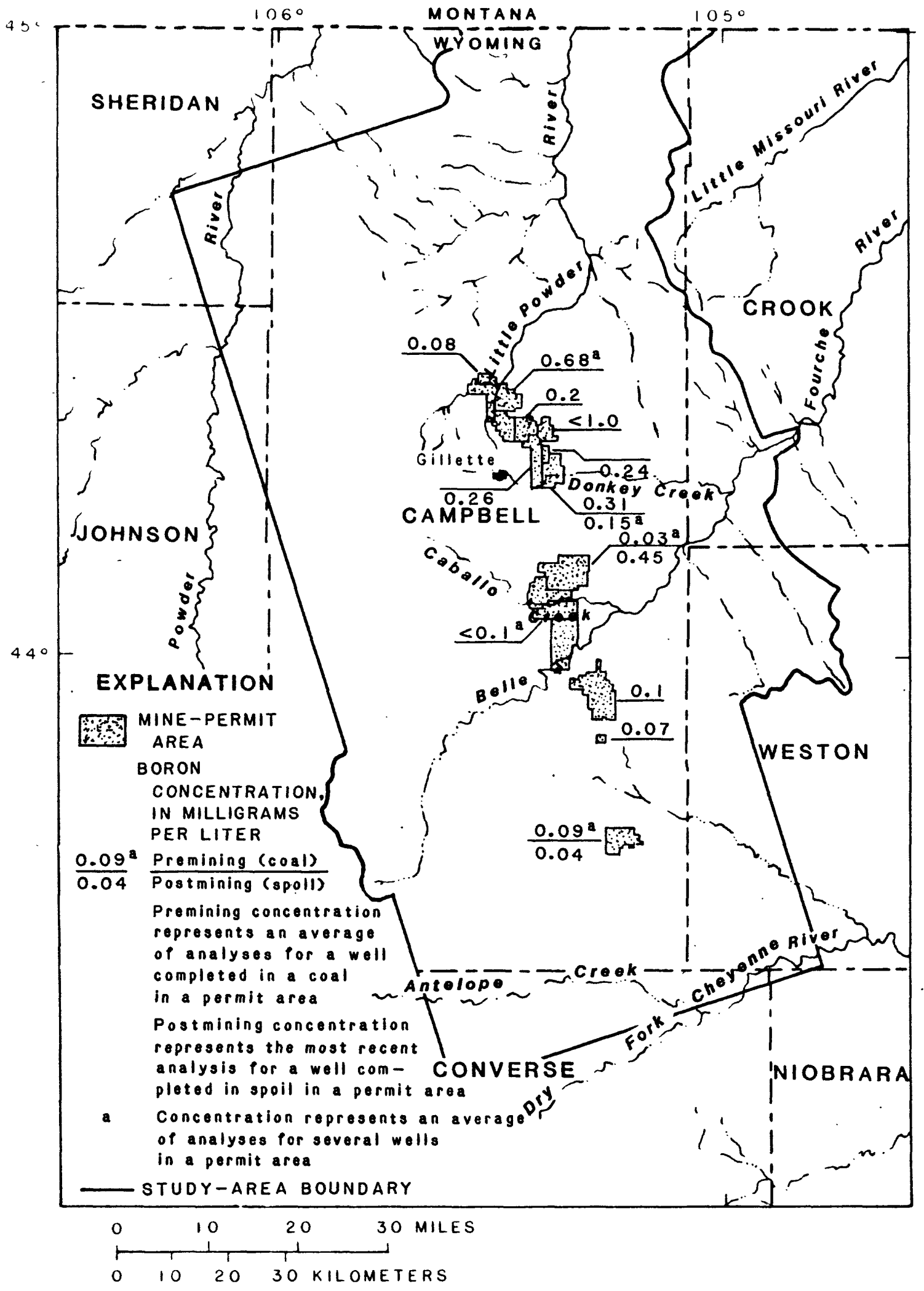

Figure 36.--Premining and postmining concentrations of boron in ground water. 


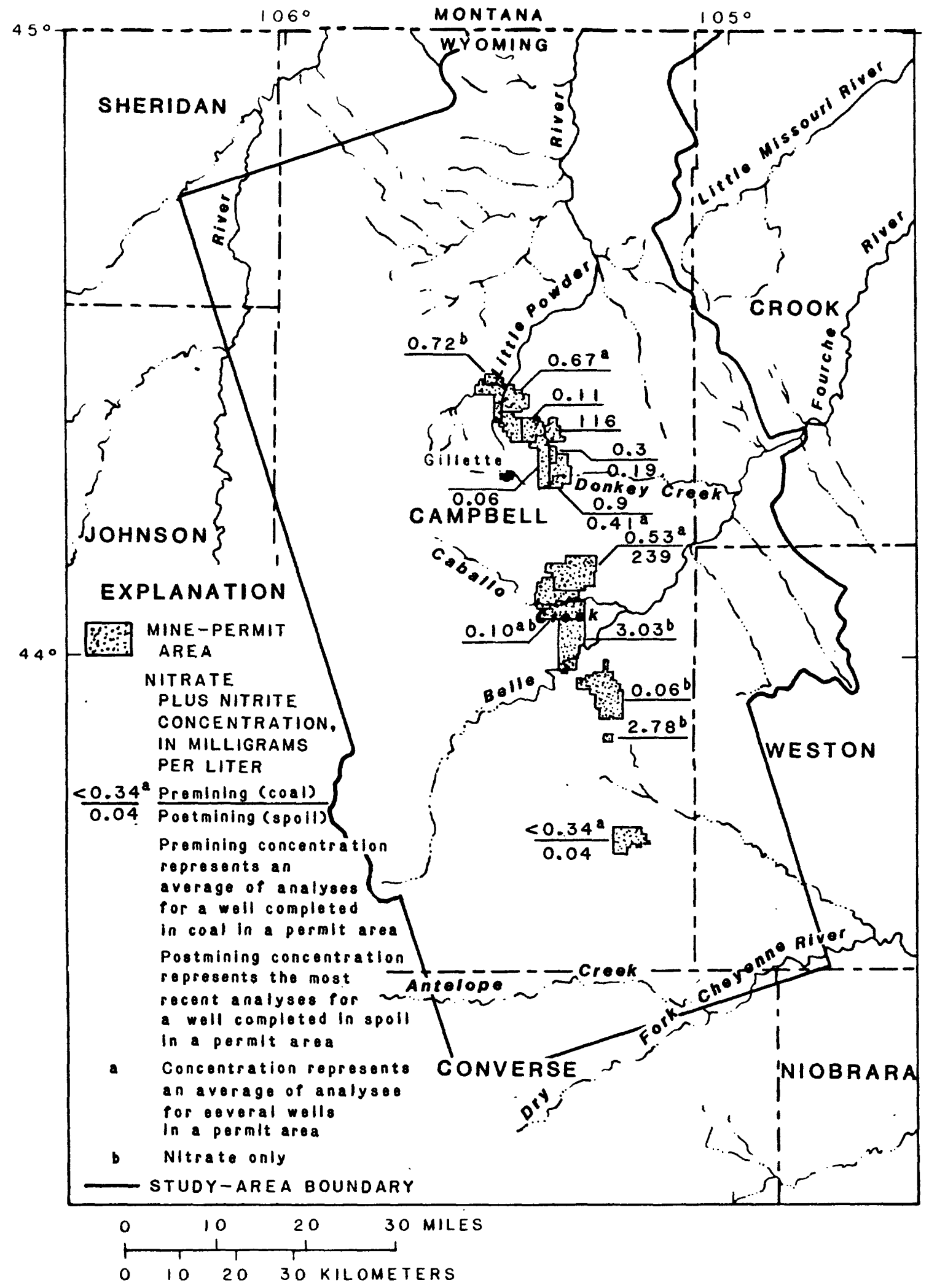

Figure 37.--Premining and postmining concentrations of nitrate plus nitrite (as nitrogen) in ground water. 


\section{SUMMARY AND CONCLUSIONS}

The study, done in cooperation with the Wyoming Department of Environmental Quality, was an attempt to evaluate the effects of surface coal mining on the surface- and ground-water systems in part of the Powder River structural basin, Wyoming. The study area consists of about $5,400 \mathrm{mi}^{2}$ in the eastern part of the Powder River structural basin, Wyoming, and includes all of the 20 major coal mines in the area. Large quantities of hydrologic data were compiled from the Wyoming Department of Environmental Quality, the Wyoming State Engineer, and the U.S. Geological Survey.

In order to determine the effects of mining on the surface-water hydrology in the Powder River structural basin, a computer model of the Belle Fourche River basin was developed. Changes in streamflow, dissolved-solids concentration, and sulfate concentration in the Belle Fourche River downstream from all anticipated mining as a result of the cumulative effects of mining and reclamation were addressed. The Hydrological Simulation Program-Fortran (HSPF) model was used. The HSPF model simulates the water budget of a drainage basin. Using precipitation data, it simulates the processes of infiltration, soil-moisture storage, evapotranspiration, surface runoff, and interflow (subsurface lateral flow through soil). Recharge to active and inactive ground-water units is simulated by a simplified calculation.

The Belle Fourche River basin, upstream from the inlet to Keyhole Reservoir at U.S. Highway $14\left(1,720 \mathrm{mi}^{2}\right)$, initially was divided into 12 land segments. The division into land segments was done to account for areal variations in precipitation, land and channel characteristics, and locations of streamflow-gaging stations used in calibration of the model. Because runoff and streamflow are greatly affected by precipitation intensity, a time step of 1 hour was chosen for the surface-water model. Hourly rainfall data were available at the Belle Ayr Mine precipitation station and three National Weather Service stations. Topographic characteristics for premining and postmining conditions used in the model are the area of each land segment, the average length of overland-flow path, and the average slope of overland-flow path for each land segment.

Streamflow data from May and June 1978 were used for model calibration. This period was most useful for determining representative values for hydrologic characteristics used in the model. Even though the early May precipitation included about 20 percent snow, it melted rapidly, and thus the effect on the volume of runoff was not significantly different from that which would have been produced from 100 percent rainfall. The time period chosen for calibration represents the premining condition; although mining already had started by 1978 , less than 0.2 percent of the drainage basin had been disturbed. The values for hydrologic characteristics were adjusted during the calibration process. These adjustments were guided by the effect each characteristic has on the simulated-flow volume, shape of different parts of the hydrograph, or dissolved-solids or sulfate concentration. 
Simulated streamflow volume for the calibration period at the downstream station, Belle Fourche River below Moorcroft, is about 6 percent less than the measured flow. The simulated and measured daily values of concentrations of dissolved solids and sulfate differed by 18 and 35 percent, respectively. The differences for dissolved-solids and sulfate concentrations probably result from inadequate calibration of variables that affect the contribution of ground-water discharge and overland runoff to total streamflow and the shortterm data base used for calibration.

Streamflow data from May and June 1982 were used for model verification. The simulated peak flows were similar to the measured peak flows for the verification period, but the simulated daily flow values were larger than the measured flow values for almost all days of the simulation period (fig. 11). Some of the lack of agreement could be the result of missing rainfall data during 1982 for some of the precipitation stations and the result of using only 1 month to establish initial soil-moisture conditions. The agreement between simulated and measured dissolved-solids and sulfate concentrations for the verification period was similar to that for the calibration period. Information about the effects of model bias on the evaluation of the effects of mining is provided later.

After calibration and verification, the model was used to calculate changes in streamflow and changes in dissolved-solids and sulfate concentrations that result from mining. For these applications of the model, measured and estimated rainfall and evaporation data for May and June 1980, a period of less than average rainfall (rainfall A), and May and June 1982, a period of greater than average rainfall (rainfall $B$ ), were used. The periods used represent a typical range, but not the extremes, of climatic conditions for a spring season. Simulated streamflows using rainfall A were small, and changes in flow from premining to during-mining and postmining conditions were less than 2.5 percent. Changes in median streamflows simulated using rainfall B ranged from 4 to 22 percent at four sites downstream from mining. Changes in mean dissolved-solids and sulfate concentrations simulated using rainfall A ranged from 1 to 7 percent from premining to postmining worst-case conditions. Simulated dissolved-solids and sulfate concentrations for flows that exceed $1.0 \mathrm{ft}^{3} / \mathrm{s}$ were decreased as much as 49 percent by rainfall $\mathrm{B}$ from premining to during-mining conditions.

The two major basins affected by coal mining in the eastern part of the Powder River structural basin are the Belle Fourche River and Little Powder River basins. Time constraints allowed surface-water modeling of only the Belle Fourche River basin; therefore, the transferability of the model to the Little Powder River basin was evaluated. However, the comparison of climate, geology, soil characteristics, vegetation, and streamflow in the two basins indicated differences that may preclude accurate prediction in the little Powder River basin using the model developed for the Belle Fourche River basin.

Land disturbance from surface coal mining may affect natural channel stability by modifying the drainage network and increasing sedimentation and erosion. The design of stable drainage networks for surface-mined areas is critical to the type and use the land may support following reclamation. The more similar postmining topography can be restored to surrounding natural conditions, the greater the likelihood of stable drainage networks and successful reclamation (Bishop, 1980). 
A sample of 102 drainage basins, all within 15 miles of present coalmining operations, was selected for determining the physical characteristics of drainage networks in the study area using the Horton analysis. Twenty-two physical characteristics were measured for each of the second- and higher order basins. A statistical summary of the values of the physical characteristics includes the minimum and maximum values measured, the arithmetic mean, the geometric mean, and the standard deviation of the sample. The physical characteristics of drainage networks usually are interrelated, and a correlation analysis was made to determine those variables that are significantly related.

Using these correlations as a guide, graphs and regression relations were developed for the physical characteristics that are significantly related and that are considered important to landscape stability. These relations can be used as aids in designing the reconstruction of drainage networks.

Hypsometric analyses made on the larger unmined basins in the study sample indicate the basins are relatively stable in their topographic development and further erosion will be slow. Statistical data from these basins can be used to help design the placement of material within a mined basin to approximate the natural landscapes in the area. However, reclaimed spoil material may not support the relief and slopes indicated by the unmined-basin measurements.

For this study, the principal potential effects of surface coal mining on the ground-water system were assumed to occur in the relatively shallow aquifers. The shallow aquifer system, as conceptualized for this report includes the aquifers in the geologic units overlying the Tullock Member of the Fort Union Formation: The Lebo Shale and Tongue River Members of the Fort Union Formation, the Wasatch Formation, and the alluvium. In order to simplify study of the complex ground-water system, the shallow aquifer system is divided in descending order into three geohydrologic units: the Wasatch-upper Tongue River aquifer, Wyodak-Anderson aquifer, and lower Tongue River-Lebo aquifer. Each unit was assumed to function as a homogeneous aquifer. The general direction of flow in the three aquifers is from the south and southwest to the north under natural, undisturbed conditions. Recharge to the Wasatch-upper Tongue River aquifer is from infiltration of precipitation and streamflow. Principal recharge to the Wyodak-Anderson aquifer is infiltration of precipitation in the outcrop area. The most significant recharge probably occurs in the areas of exposed clinker, where recharge may be as much as an order of magnitude greater than elsewhere. Discharge from the shallow aquifer system occurs primarily by underflow out of the study area and discharge to perennial streams. Evapotranspiration, discharge to springs, and pumping for stock and domestic use are considered minor sources of discharge from the ground-water system.

To predict the effects of mining on the ground-water system in the study area, an attempt was made to mathematically simulate ground-water flow. Although the computer model was not successfully calibrated, the modeling effort was briefly documented to describe the hydraulic properties and to illustrate the problems of modeling the complex aquifer system in the Powder River structural basin. 
The modeling effort failed principally because of insufficient quantity and quality of data to define the aquifer system in the Powder River structural basin of Wyoming. For example, data to define the spatial distribution of aquifer properties are limited; data to define ground-water recharge and discharge are incomplete, especially for steady-state conditions; and data to define the hydraulic-head distribution within and between aquifers are questionable. The limited time available to collect and assemble data, to process the data into the format needed for computer entry, and to apply the model was a severe constraint.

The premining concentrations of dissolved solids in ground water in the Wyodak-Anderson aquifer ranged from 600 to $3,934 \mathrm{mg} / \mathrm{L}$; the postmining concentrations ranged from 1,560 to $6,483 \mathrm{mg} / \mathrm{L}$. Concentrations increased in all four permit areas where both premining and postmining data are available. The premining $\mathrm{pH}$ values ranged from 7.2 to 7.9 , and the postmining values ranged from 6.5 to 7.5 , with values for three out of four permit areas decreasing from premining to postmining. Both premining and postmining sulfate concentrations are variable. Premining concentrations ranged from 4.9 to $2,140 \mathrm{mg} / \mathrm{L}$; postmining concentrations ranged from 524 to $2,960 \mathrm{mg} / \mathrm{L}$. Manganese concentrations increased in most permit areas. Premining values ranged from 0.04 to $0.26 \mathrm{mg} / \mathrm{L}$; postmining values ranged from 0.16 to $5.84 \mathrm{mg} / \mathrm{L}$. Premining concentrations of boron ranged from 0.03 to $0.68 \mathrm{mg} / \mathrm{L}$; postmining concentrations ranged from 0.04 to $0.45 \mathrm{mg} / \mathrm{L}$. Premining nitrate plus nitrite concentrations ranged from 0.06 to $116 \mathrm{mg} / \mathrm{L}$; postmining concentrations ranged from 0.04 to $239 \mathrm{mg} / \mathrm{L}$. 


\section{REFERENCES}

Beikman, H.M., 1962, Geology of the Powder River basin, Wyoming and Montana, with reference to subsurface disposal of radioactive wastes: U.S. Geological Survey Trace Elements Investigations Report TEI-823, $85 \mathrm{p}$.

Bergstrom, F.W., 1985, Determination of longitudinal profile for stream channel reclamation, in Second hydrology symposium on surface coal mines in the Northern Great Plains: Gillette, Wyo., Gillette Area Groundwater Monitoring Organization, Colorado Ground-Water Association and Wyoming Water Research Center, Proceedings, p. 29-60.

Bishop, M.B., 1980, Geomorphic concepts and their application to ephemeral stream channel reclamation, in Second Wyoming Mining Hydrology Symposium, Laramie, Wyoming, 1980, Proceedings: University of Wyoming, p. 249-261.

Breckenridge, R.M., Glass, G.B., Root, F.K., and Wendell, W.G., 1974, Campbell County, Wyoming; Geologic map atlas and summary of land, water and mineral resources: The Geological Survey of Wyoming County Resource Series No. 3, 9 sheets.

Clifton, P.M., and Neuman, S.P., 1982, Effects of kriging and inverse modeling on conditional simulation of the Aura Valley aquifer in southern Arizona: Water Resources Research, v. 18, no. 4, p. 1215-1234.

Cooley, R.L., 1977, A method of estimating parameters and assessing the reliability for models of steady state groundwater flow, Theory and numerical properties: Water Resources Research, v. 13, no. 21, p. 318-324.

1979, A method of estimating parameters and assessing the reliability for models of steady state groundwater flow, 2, Application of statistical analysis: Water Resources Research, v. 15, no. 3, p. 603-617.

1982, Incorporation of prior information on parameters into nonlinear regression groundwater flow models, 1, Theory: Water Resources Research, v. 18 , no. 4, p. 965-976.

1983, Incorporation of prior information on parameters into nonlinear regression groundwater flow models, 2, Applications: Water Resources Research, v. 19, no. 3, p. 662-676.

Crawford, N.H., and Linsley, R.K., Jr., 1966, Digital simulation in hydrology; Stanford watershed model IV: Palo Alto, Calif., Stanford University, Department of Civil Engineering, Technical Report 39, 208 p.

1982, Stochastic modeling of groundwater flow by unconditional simulation and the direct problem: Water Resources Research,'v. 18.

Delhomme, J.P., 1979, Spatial variability and uncertainty in groundwater flow parameters: A geostatistical approach: Water Resources Research, v. 15, no. 2 , p. 269-280.

Denson, N.M., Dover, J.H., and Osmonson, L.M., 1980, Lower Tertiary coal bed distribution and coal resources of the Reno Junction-Antelope Creek area, Campbel1, Converse, Niobrara, and Weston Counties, Wyoming: U.S. Geological Survey Miscellaneous Investigations Map I-1201, scale 1:125,000.

Divis, A.F., and Tarquin, P.A., 1981, The geohydrologic regime of the Powder River Basin: Wheat Ridge, Colo., Environmental Science Associates, January 1981 (revised), $109 \mathrm{p}$.

Druse, S.A., Dodge, K.A. and Hotchkiss, W.R., 1981, Base flow and chemical quality of streams in the Northern Great Plains area, Montana and Wyoming, 1977-78: U.S. Geological Survey Water-Resources Investigations Open-File Report 81-692, 60 p. 
Freeze, R.A., and Witherspoon, P.A., 1967, Theoretical analysis of regional groundwater flow, 2, Effect of water table configuration and subsurface permeability variation: Water Resources Research, v. 3, no. 2, p. 623-634.

Gifford, G.F., 1981, Rainfall simulator studies--1981: Logan, Utah, Utah State University Foundation, $18 \mathrm{p}$.

Gillette Area Groundwater Monitoring Organization (GAGMO), 1983, 1982 GAGMO annual report: Cheyenne, Wyo., Wyoming State Library, variable pagination.

Hadley, R.F.; and Keefer, W.R., 1975, Map showing some potential effects of surface mining of the Wyodak-Anderson coal, Gillette area, Campbell County, Wyoming: U.S. Geological Survey Miscellaneous Investigations Map I-848-F, scale $1: 125,000$.

Harvey; M.D., Watson, C.C., and Schumm, S.A., 1985, Stream channel restoration criteria, in Second hydrology symposium on surface coal mines in the Northern Great Plains: Gillette, Wyo., Gillette Area Groundwater Monitoring Organization, Colorado Ground-Water Association, and Wyoming Water Research Center, Proceedings, p. 61-73.

Hodson, W.G., Pearl, R.H., and Druse, S.A., 1973 [1974], Water resources of the Powder River basin and adjacent areas, northeastern Wyoming: U.S. Geological Survey Hydrologic Investigations Atlas HA-465, 4 sheets.

Horton, R.E., 1945, Erosional development of streams and their drainage basins; hydrophysical approach to quantitative morphology: Geological Society of America Bulletin, v. 56, p. 275-370.

Hotchkiss, W.R., and Levings, J.F., 1986, Hydrogeology and simulation of water flow in strata above the Bearpaw Shale and equivalents of eastern Montana and northeastern Montana: U.S. Geological Survey Water-Resources Investigations Report 85-4281, 72 p.

Johanson, R.C., Imhoff, J.C., and Davis, H.H., Jr., 1981, Users manual for hydrological simulation program-Fortran (HSPF), release 7: Athens, Ga., Environmental Research Laboratory, 677 p.

Johanson, R.C., and Kittle, J.L., 1983, Design, programming and maintenance of HSPF: American Society of Civil Engineers Journal of Technical Topics, v. 109, no. 1, p. 41-57.

Jordan, P.R., Bloyd, R.M., and Daddow, P.B., 1984, An assessment of cumulative impacts of coal mining on the hydrology in part of the Powder River structural basin, Wyoming--A progress report: 'U.S. Geological Survey Water-Resources Investigations Report 83-4235, 25 p.

Journel, A.G., and Huijbregts, C.J., 1978, Mining geostatistics: Academic Press, New York, 600 p.

Kearney, W., 1985, Channel reconstruction efforts to date in Wyoming, in Second hydrology symposium on surface coal mines in the Northern Great Plains: Gillette, Wyo., Gillette Area Groundwater Monitoring Organization, Colorado Ground-Water Association and Wyoming Water Research Center, Proceedings, p. 74, 75.

Keys, W.S., and MacCary, L.M., 1971, Application of borehole geophysics to water-resources investigations: U.S. Geological Survey Techniques of Water-Resources Investigations, Book 2, Chap. E1, 126 p.

Kitanidis, P.K., and Vomvoris, E.G., 1983, A geostatistical approach to the inverse problem in ground water modeling (steady state) and onedimensional simulations: Water Resources Research, v. 19, no. 3, p. $677-690$. 
Knutson, K., 1982, Regional comparison of drainage basin morphometry--Eastern Powder River Basin, Wyoming, in Hydrology symposium on surface coal mines in the Powder River Basin of Wyoming: Gillette, Wyo., Gillette Area Groundwater Monitoring Organization and American Institute of Mining Engineers, Proceedings, p. 157-172.

Koch, Donald, Ringrose, C.D., Moore, R.C., and Brooks, D.L., 1982, Monitoring and modeling of shallow ground-water systems in the Powder River basin: Hittman Associates, Inc., Englewood, Colo., 359 p. (Appendices A through U, separate volume).

Leopold, L.B., and Miller, J.P., 1956, Ephemeral streams--hydraulic factors and their relation to the drainage net: U.S. Geological Survey Professional Paper 282-A, p. 1-37.

Lewis, B.D., and Hotchkiss, W.R., 1981, Thickness, percent sand, and configuration of shallow hydrogeologic units in the Powder River basin, Montana and Wyoming: U.S. Geological Survey Miscellaneous Investigations Map I-1317, scale 1:1,000,000, 6 sheets.

Lidstone, C.D., 1982, Stream channel reconstruction and drainage basin stability, in Hydrology symposium on surface coal mines in the Powder River Basin of Wyoming: Gillette, Wyo., Gillette Area Groundwater Monitoring Organization and American Institute of Mining Engineers, Proceedings, p. 43-58.

Love, J.D., and Christiansen, A.C., 1985, Geologic map of Wyoming: Geological Survey of Wyoming, scale 1:500,000.

Lowham, H.W., 1976, Techniques for estimating flow characteristics of Wyoming streams: U.S. Geological Survey Water-Resources Investigations Report $76-112,83 \mathrm{p}$.

Lowry, M.E., Wilson, J.F., Jr., and others, in press, Hydrology of Area 50, Northern Great Plains and Rocky Mountain coal provinces, Wyoming and Montana: U.S. Geological Survey Water-Resources Investigations Open-File Report 83-545.

Morris, D.A., and Johnson, A.I., 1967, Summary of hydrologic and physical properties of rock and soil materials, as analyzed by the Hydrologic Laboratory of the U.S. Geological Survey 1948-60: U.S. Geological Survey Water-Supply Paper 1839-D, 42 p.

Parkhurst, D.L., Plummer, L.N., and Thorstenson, D.C., 1982, BALANCE--A computer program for geochemical calculations: U.S. Geological Survey Water-Resources Investigations Report 80-96, $210 \mathrm{p}$ :

Parkhurst, D.L., Thorstenson, D.C., and Plummer, L.N., 1980, PHREEQE--A computer program for calculating mass transfer for geochemical reactions in ground water: U.S. Geological Survey Water-Resources Investigations report $82-14,29 \mathrm{p}$.

Plummer, L.N., Jones, B.F., and Truesdall, A.H., 1976, WATEQF--A FORTRAN IV version of WATEQ, a computer program for calculating chemical equilibrium of natural waters: U.S. Geological Survey Water-Resources Investigations Report 76-13, $61 \mathrm{p}$.

Rahn, P.H., 1976, Potential of coal strip-mine spoils as aquifers in the Powder River basin: Old West Regional Commission, project no. 10470025, Billings, Mont., $108 \mathrm{p}$.

Rankl, J.G., 1982, An empirical method for determining average soil infiltration rates and runoff, Powder River structural basin, Wyoming: U.S. Geological Survey Water-Resources Investigations Report 81-76, 38 . 
Reed, J.E., 1980, Type curves for selected problems of flow to wells in confined aquifers: U.S. Geological Survey Techniques of Water-Resources Investigations Report, book 3, chap. B3, $106 \mathrm{p}$.

Rehm, B.W., Groenewald, G.H., and Morin, K.A., 1980, Hydraulic properties of coal and related materials, Northern Great Plains: Ground Water, v. 18, no. 6, p. 551-561.

Schumm, S.A., 1977, The fluvial system: New York, John Wiley and Sons, 338 p. Strahler, A.N., 1952, Hypsometric (area-altitude) analysis of erosional topography: Geological Society of America Bulletin, v. 63, p. 1117-1142. 1964, Quantitative geomorphology of drainage basins and channel networks, in V.T. Chow, ed., Handbook of applied hydrology: New York, McGraw-Hill, pp. 4-39 to 4-76.

Tarquin, P.A., and Baeder, L.D., 1982,1 Stream channel reconstruction--The problem of designing lower order streams, in Hydrology symposium on surface coal mines in the Powder River Basin of Wyoming: Gillette, Wyo., Gillette Area Groundwater Monitoring Organization and American Institute of Mining Engineers, Proceedings, p. 257-270.

Trescott, P.C., 1975, Documentation of finite-difference model for simulation of three-dimensional ground-water flow: U.S. Geological Survey Open-File Report 75-438, 32 p.

Trescott, P.C., and Larson, S.P., 1976, Documentation of finite-difference model for simulation of three-dimensional ground-water flow, supplement to Open-File Report 76-591, $21 \mathrm{p}$.

U.S. Department of Commerce, 1975-82, Climatological data annual summary, Wyoming: National Oceanic and Atmospheric Administration, v. 84-91, no. 13 (published annually).

1982, Monthly normals of temperatures, precipitation, and heating and cooling degree days 1951-80: National Oceanic and Atmospheric Administration, Climatography of the United States No. 81 (Wyoming), $17 \mathrm{p}$.

U.S. Department of the Interior, 1979, Proposed development of coal resources in the eastern Powder River basin, Wyoming: Cheyenne, Wyo., U.S. Bureau of Land Management (lead agency), Final environmental statement, variable pagination.

U.S. Geological Survey, 1976, Hydrologic unit map--1974, State of Wyoming: U.S. Geological Survey map, scale 1:500,000.

1976, Water resources data - Wyoming, water year 1975: U.S. Geological Survey Water-Data Report WY-75-1.

1977-82, Water resources data - Wyoming, water years 1976-81--volume 1: U.S. Geological Survey Water-Data Reports WY-76-1 to WY-81-1 (published annually).

1983, Water resources data - Wyoming, water year 1982: U.S. Geological Survey Water-Data Report WY-82-1.

Wyoming Department of Environmental Quality, 1980, Hydrology: Cheyenne, Wyo., Land Quality Division Guideline No. 3, 25 p.

Wyoming Geological Association Guidebook Committee, 1958, Guidebook, Powder River basin, 1958: Wyoming Geological Association, 341 p.

Wyoming State Legislature, 1973, Wyoming environmental quality act: Wyoming Department of Environmental Quality, statutes 35-502.1 to 35-502.56, $32 \mathrm{p}$.

Young, J.F., and Singleton, P.C., 1977, Wyoming general soil map: University of Wyoming Agriculture Experiment Station Research Journal, no. 117, $40 \mathrm{p}$. 